\title{
Kyiv Institutional Buildings Sector Energy Efficiency Program: Lending and Implementation Assessment
}

August 1997

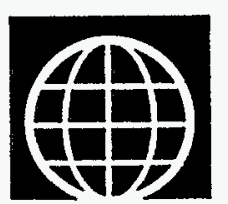

Global

Studies

Program

Pacific Northwest National Laboratory Advanced International Studies Unit 


\title{
DISCLAIMER
}

This report was prepared as an account of work sponsored by an agency of the United States Government. Neither the United States Government nor any agency thereof, nor Battelle Memorial Institute, nor any of their employees, makes any warranty, express or implied, or assumes any legal liability or responsibility for the accuracy, completeness, or usefulness of any information, apparatus, product, or process disclosed, or represents that its use would not infringe privately owned rights. Reference herein to any specific commercial product, process, or service by trade name, trademark, manufacturer, or otherwise does not necessarily constitute or imply its endorsement, recommendation, or favoring by the United States Government or any agency thereof, or Battelle Memorial Institute. The views and opinions of authors expressed herein do not necessarily state or reflect those of the United States Government or any agency thereof.

\section{PACIFIC NORTHWEST NATIONAL LABORATORY operated by \\ BATTELLE \\ for the \\ UNITED STATES DEPARTMENTT OF ENERGY} under Contract DE-ACO6-76RLO 1830

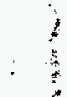 \\ Printed in the United States of America \\ Available to DOE and DOE contractors from the \\ Office of Scientific and Technical Information, P.O. Box 62, Oak Ridge, TN 37831; \\ prices available from (615) 576-8401. \\ Available to the public from the National Technical information Service, \\ U.S. Department of Commerce, 5285 Port Royal Rd., Springfield, VA 22161
}




\section{DISCLAmizR}

Portions of this doement moy be illegibie in electronic image produets. Images are produced from the best available original document 
PNNL-11653

UC-350

\section{Kyiv Institutional Buildings Sector Energy Efficiency Program: Lending and Implementation Assessment}

T. J. Secrest

S. L. Freeman
A. Popelka ${ }^{(a)}$
P. A. Shestopal ${ }^{(\text {b) }}$
E. V. Gagurin ${ }^{(b)}$

August 1997

Prepared for

the U.S. Department of Energy

under Contract DE-AC06-76RLO 1830

Pacific Northwest National Laboratory

Richland, Washington 99352
(a) Tysak Engineering.
(b) Agency for Rational Energy Use and Ecology. 


\section{Summary}

The government of Ukraine, through the State Committee of Energy Conservation (State Committee), is considering the implementation of energy efficiency measures in state and municipal institutional buildings in the city of Kyiv. The State Committee entered into an agreement with the U.S. Department of Energy to conduct an assessment of the institutional buildings sector heating and hot water efficiency potential supplied by district heat to support a potential World Bank loan for implementing such a program. This assessment summarizes a detailed estimate of the institutional sector energy efficiency potential (PNNL 1997) and provides options for the implementation of such a program.

The institutional buildings sector energy efficiency potential was developed for state- and municipal(city of Kyiv) owned and occupied healthcare, educational, and cultural buildings, of which there are an estimated 1,678 buildings comprising 7.2 million square meters of floorspace. Institutional buildings consume an estimated 2.8 million Gcal of energy annually from the district heating system, which is $16 \%$ of the buildings sector energy consumption from the district heating system-the 1,678 buildings considered in this assessment are estimated to consume about one-half of the institutional sector energy. The weighted average efficiency improvement and cost per square meter is $26 \%$ and $\$ 4.31$, respectively. The energy efficiency improvements and costs are dominated by heat control measures supplemented by weatherization and hot water measures; the installation of a heat meter is factored into each installation.

The efficiency improvements are projected to reduce budgetary expenditures by over $\$ 9$ million annually and reduce natural gas imports by about 57 million cubic meters and mazut imports by about 81 thousand tonnes annually with a combined annual value of $\$ 5.8$ million. Direct employment for administering the program and installing the measures is projected to be 263 full-time equivalent (FTE) years over the 5-year life of the project (an FTE year is one person working full time for 1 year. Because most of the installation activity occurs in years 2 through 5 , the average is about 63 FTEs per year). Although indirect employment associated with the manufacture of equipment and materials was not estimated, it is expected to be positive and adds to the direct increase in employment. In addition to economic benefits, annual emissions are expected to be reduced by 332 metric tonnes of $\mathrm{NO}_{\mathrm{x}}, 232$ metric tonnes of $\mathrm{SO}_{x}$, and 85,427 metric tons of $\mathrm{CO}_{2}$. None of the measures considered are expected to have negative health impacts or other environmental impacts. Finally, institutional sector energy efficiency improvements are expected to alleviate conditions of underheating that exist due to capacity constraints.

Alternate financial structures were examined for the loan disbursement and service. These ranged from a centralized process where the Ministry of Finance and Kyiv Municipal Department of Finance retain the responsibility for the loan and deduct the required amount from the energy budget allocated to each agency to a decentralized process where each participating agency is responsible for repayment of its share of the loan. A primary benefit of the centralized option is stronger assurance of repayment and realization of the budgetary savings at the highest level so that priority budgetary items can be addressed. Alternatively, the primary benefit of the decentralized option is that an incentive exists for participants that allow them to redirect the 'savings' from their energy bills to other areas within their purview. 
Related to the financial structure is the implementation structure for installing the equipment/ measures. Decree \#414 passed by the Cabinet of Ministers in May 1997 stipulates the formation of an Inter-Agency Work Group to provide oversight for the implementation of the program. It has been assumed that a Project Implementation Organization (PIO) will report to the Inter-agency Work Group and provide day-to-day management for the implementation activity. Options developed for the PIO relate to the creation of one or several PIOs to manage the implementation. Major benefits of a single PIO are lower cost, avoided duplication of effort and capability, and increased probability of replicating the program in other sectors and locations. The major benefits of multiple PIOs housed in the participating organizations are greater 'ownership' by the participants and greater familiarity with the conditions within a given building type.

The estimated cost of the program over the 5-year period by cost category is:

\begin{tabular}{|l|c|}
\hline Installation & $\$ 31.1$ million \\
\hline Administration & $\$ 3.5$ million \\
\hline Contingency & $\$ 3.5$ million \\
\hline Total & $\$ 38.0$ million \\
\hline
\end{tabular}

Installation reflects the cost of equipment, materials, and labor to physically install the measures; administration reflects the PIO cost to provide day-to-day management of the installations; and contingency applies to extension of the program to additional buildings/participants and/or unexpected costs.

Alternative lending structures were examined to assess the cash-flow implications and national benefit as measured in cash outflow and equivalent price of natural gas. The lending structures analyzed the repayment term as offered by the World Bank, rapid repayment, and use of third-party financing to supplement funding provided by the World Bank. The terms of the World Bank loan were analyzed for the provision of $80 \%$ of the capital at an $8.25 \%$ annual interest rate for a 15 -year period with a 5-year grace period on the principal; the terms of the third-party loan were for a $25 \%$ annual interest rate. This analysis supported a number of conclusions:

- The greater the share of the program assumed by Ukraine, the greater the national benefit and the greater the negative cash flow during the initial years of the loan.

- The more rapid the repayment of loan(s), the greater the national benefit.

- It is desirable to obtain as much grant financing as possible to reduce the initial negative cash flow.

- If third-party financing is relied upon, it is desirable to obtain as low a rate as possible to maximize the national benefit.

A two-phased schedule for implementation activities has been developed. Using this schedule, a limited number of buildings would be retrofitted in the first phase occurring in the first year of the 
program and remainder of the buildings would be retrofitted in the second phase over the subsequent 4 years. A limited Phase I is necessary to 1) verify the cost and performance of recommended measures and 2) refine the management and implementation procedures that include the audit for each building, physical installation, providing quality assurance for and acceptance of installations, verification procedures, and reporting procedures.

The authors feel that:

- The Technical Assessment has adequately identified the energy efficiency potential and combined with the Lending and Implementation Assessment has identified the cost of obtaining that potential.

- The ongoing discussions will address the many issues framed by the Lending and Implementation Assessment. The most important of these are the structures for servicing the loan and implementing the measures as they relate to the quality of the installations, the performance of the efficiency improvements, the verification of the efficiency improvements, incentives to participate and ensure persistence (longevity), and the replication of the program to other sectors and locations.

- Further development of project management and implementation/installation procedures is best accomplished by the Inter-agency Work Group and the PIO to ensure agreement and ownership. 



\section{Acknowledgments}

This assessment was made possible by funding provided by the U.S. Department of Energy (DOE) under a Memorandum of Cooperation between the DOE and Ukraine State Committee for Energy Conservation (SCEC). Recognition is provided to Brian Castelli and Elizabeth Arner of DOE's Office of Energy Conservation and Renewable Energy for their perseverance and leadership in this effort. Appreciation is extended to Carolyn Gochenour and Pentti Aro of the World Bank and to Tord Holmstrom of EnergiPlanerarna $\mathrm{AB}$ for their coaching and many suggestions and comments. Special thanks are extended to Mykhailo Kovalko, Nikolai Raptsoun, and Georgy Panchenko of the SCEC for their in-country leadership to facilitate data collection and agreements with Ukrainian participants. 



\section{Abbreviations and Acronyms}

$\mathrm{A} / \mathrm{C}$

AISU

ARENA-ECO

ASEAM5

ASHRAE

CFC

CHP

$\mathrm{CO}_{2}$

$\mathrm{dm}^{3}$

DOE

DWH

ECOs

EHDP

ESCO

FLEOH

FTE

GC

Gcal

GJ

GWh

IBRD

ICB

IEA

IRR

IS

$\mathrm{K}$

kcal

KGTKE

KIBA

$\mathrm{km}$

KRB

$\mathrm{kWh}$

m

MJ

NCB

NEMVP

$\mathrm{NO}_{x}$

NPV

O\&M air conditioning

Advanced International Studies Unit

Agency for Rational Energy Use and Ecology.

A Simplified Energy Analysis Method, Version 5

American Society for Heating, Refrigeration, and Air Conditioning Engineers

chlorofluorocarbon

combined heat and power

carbon dioxide

cubic decimeters

U.S. Department of Energy

domestic water heating

energy conservation opportunities

Enterprise Housing Divestiture Project

Energy Services Contractor

full load equivalent operating hours

full-time equivalent

general contractor

gigacalories

gigajoules

gigawatt-hours

International Bank for Reconstruction and Development

International Competitive Bidding

International Energy Agency

internal rate of return

international shopping (rules)

degrees Kelvin

kilocalories

Kyiv Municipal District Heat Company

Kyiv Institutional Building Assessment

kilometer

Hryvna

kilowatt-hours

meter

megajoule

National Competitive Bidding

North America Energy Measurement and Verification Protocol

oxides of nitrogen

net present value

operations and maintenance 


$\begin{array}{ll}\text { ODS } & \text { ozone depleting substances } \\ \text { PIO } & \text { Project Implementation Organization } \\ \text { PNNL } & \text { Pacific Northwest National Laboratory } \\ \text { QA } & \text { quality assurance } \\ \text { RFP } & \text { request(s) for proposal(s) } \\ \text { R-Value } & \text { resistance to heat flow, defined as thickness/thermal conductivity } \\ \text { RRR } & \text { required rate of return } \\ \text { SBD } & \text { standard bidding document } \\ \text { SCEC } & \text { State Committee for Energy Conservation } \\ \text { SO } & \text { oxides of sulfur } \\ \text { TAS } & \text { technical audit support } \\ \text { TETS } & \text { combined heat and power station } \\ \text { TMY } & \text { typical meteorological year } \\ \text { U-Value } & \text { overall heat transfer coefficient } \\ \text { VAT } & \text { value added tax } \\ \text { W } & \text { watt } \\ \text { WO } & \text { work order }\end{array}$

\section{Conversion Factors}

$\begin{aligned} 1 \mathrm{Gcal} & =1163 \mathrm{kWh} \\ 1 \mathrm{Gcal} & =4.186 \mathrm{GJ} \\ 1 \mathrm{GJ} & =278 \mathrm{kWh}\end{aligned}$ 


\section{Contents}

Summary

iii

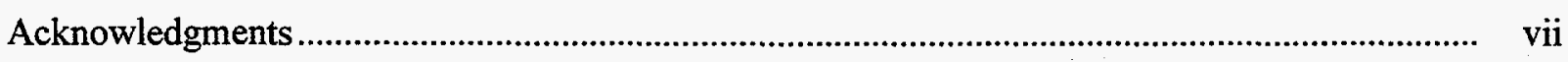

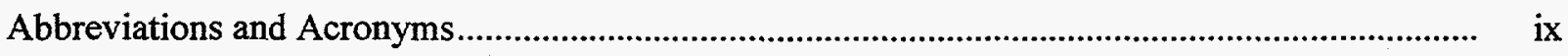

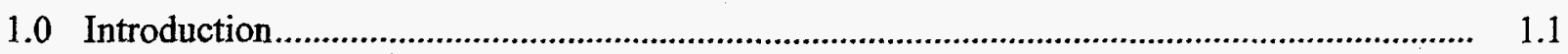

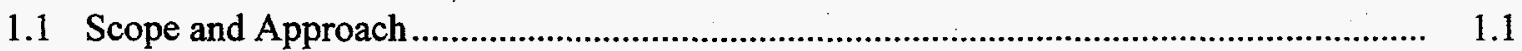

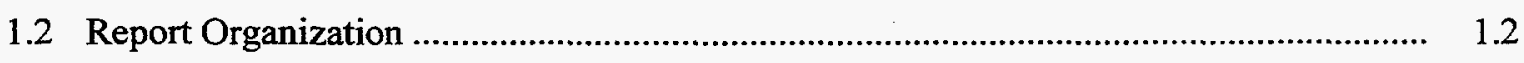

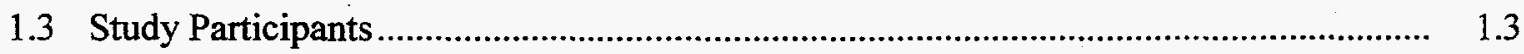

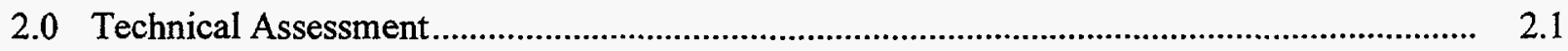

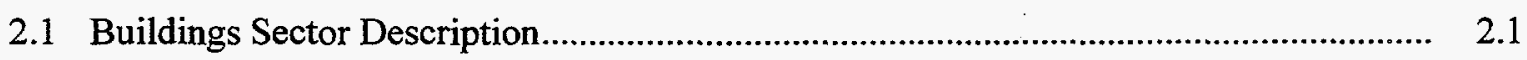

2.2 Thermal Consumption Baseline …............................................................................ 2.3

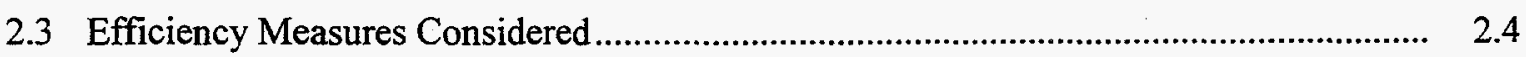

2.4 Technical Assessment Methodology .................................................................. 2.5

2.4.1 Engineering Analysis................................................................................... 2.6

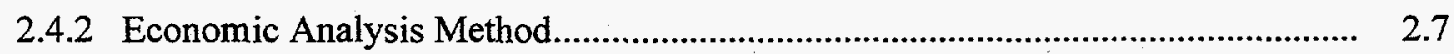

2.5 Efficiency Potential Assessment ......................................................................... 2.10

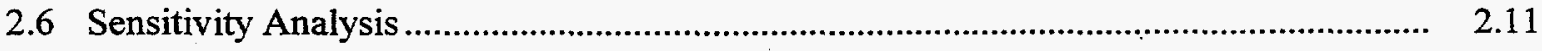

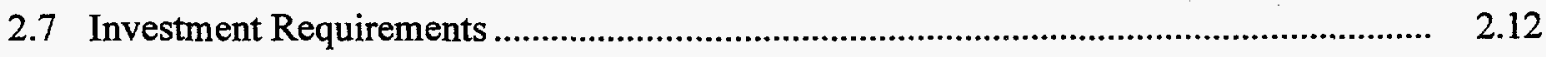


3.0 Impacts Assessment

3.1 Economic Impacts

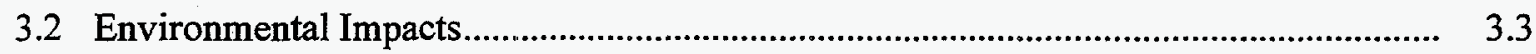

3.2.1 Emissions

3.2.2 Health and Safety.

3.2.3 Indoor Air Quality

3.2.4 Soil Contamination

3.2.5 Ozone Depleting Substances

4.0 Lending Structure..

4.1 Lending Structure and Management Responsibility

4.2 Loan Disbursement

4.3 Loan Service

4.3.1 Budget Allocation Process.

4.8

4.3.2 Repayment Options

5.0 Implementation Structure

5.1 Installation Responsibilities

5.1.1 Example Implementation/Installation Structure Options

5.1.2 Installation Recommendations

5.2 Ensuring Persistence

6.0 Risk Assessment 
7.0 Implementation and Financing Schedules.

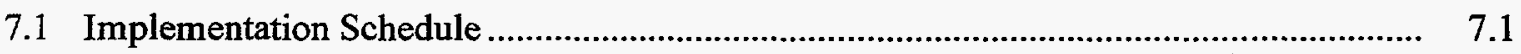

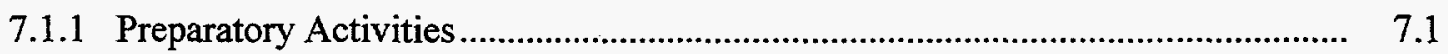

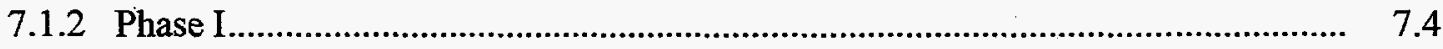

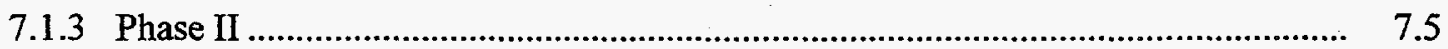

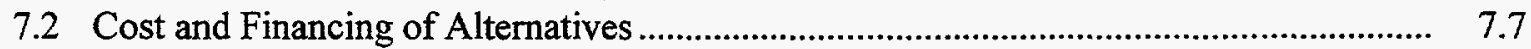

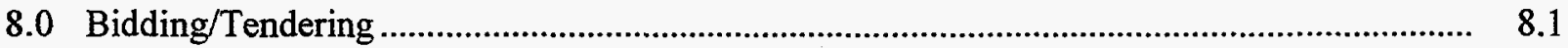

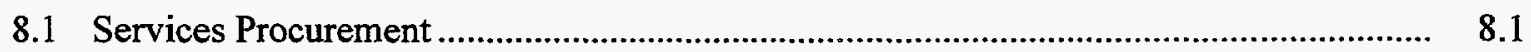

8.2 Design, Installation, and Equipment/Materials Procurement..................................... 8.2

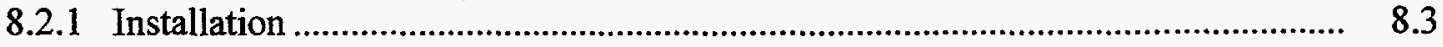

8.2.2 Procurement of Materials ................................................................................ 8.4

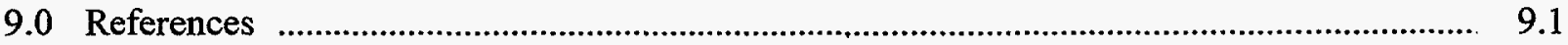

Appendix A - Institutional Buildings Detailed Technical Assessment Data ............................... A.1

Appendix B - Regulations on Foreign Loans ........................................................................ B.1

Appendix C - Staff Capabilities and Budget............................................................................. C.1

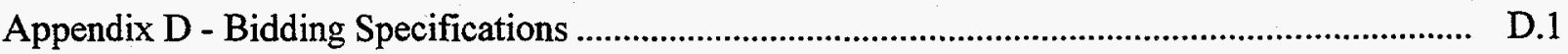

Appendix E - Proposed Energy Efficiency Verification Process ................................................ E.1 


\section{Figures}

4.1 The Financial/Lending Management Structure According to Decree \#414 ........................ 4.3

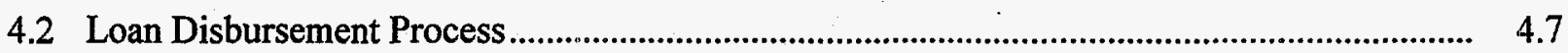

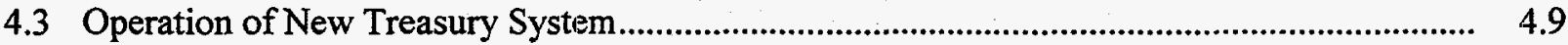

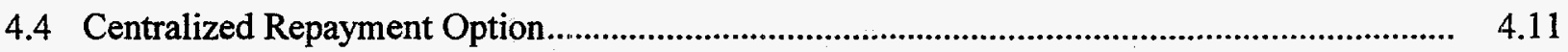

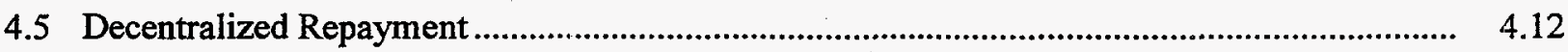

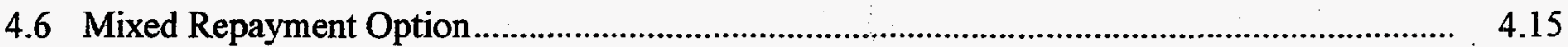

5.1 Consolidated Project Implementation Organization and Installation

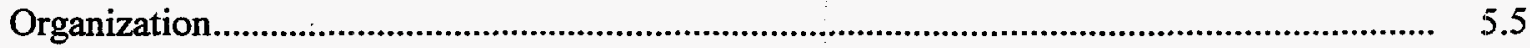

5.2 Separated Project Implementation Organization and Installation Organization .................... $\quad 5.6$

5.3 Separated Project Implementation Organization and Installation Organization .................... 5.6 


\section{Tables}

2.1 Number and Floorspace of Institutional Buildings by Type, 1996

2.2 Baseline Heat and Hot Water Energy Consumption by the Institutional Sector

2.3 Efficiency Measures Considered and Cost Per Unit.

2.4 Institutional Sector Efficiency Potential

2.5 Internal Rate of Return Switching Value for Energy Savings and Installed Costs - Institutional Buildings

2.6 Institutional Buildings Sector Investment Requirements

3.1 Secondary Impacts.

4.1 Options for Organization Responsible for the Project

4.2 Collection and Repayment Options for Servicing the Loan

5.1 Organizational Options for Installation of Energy Efficiency Equipment and Measure

5.2 Administrative Options for Providing O\&M Education/Training and Incentives

7.1 Example Implementation Schedule

7.2 Financing Scenario 1a for the Kyiv Institutional Building Assessment

7.3 Financing Scenario $1 \mathrm{~b}$ for the Kyiv Institutional Building Assessment

7.4 Financing Scenario 2a for the Kyiv Institutional Building Assessment.

7.5 Financing Scenario $2 b$ for the Kyiv Institutional Building Assessment

7.6 Financing Scenario 3a for the Kyiv Institutional Building Assessment

7.7 Financing Scenario $3 \mathrm{~b}$ for the Kyiv Institutional Building Assessment 
7.8 Summary of Financing Scenarios $1 \mathrm{a}$ through $3 \mathrm{~b}$ for Potential $\$ 40$ Million

Kyiv Institutional Building Assessment Project.

8.1 Summary of Estimated Material Requirements and Material and Labor Costs

8.8 


\subsection{Introduction}

The government of Ukraine, through the State Committee of Energy Conservation (State Committee), is considering the implementation of energy efficiency measures in state and municipal institutional buildings in the city of Kyiv. The State Committee entered into a Memorandum of Cooperation with the U.S. Department of Energy (DOE) to conduct an assessment of the institutional buildings sector efficiency potential. This assessment will be used to support a potential loan by the World Bank for implementing a buildings efficiency improvement program in Kyiv.

This report provides an assessment of the options for structuring the lending scenarios and the implementation of the program. Components to the lending structure are options for the disbursement of funds, options for the loan service, and other financial options and considerations. Program implementation includes management structures, reporting, installation activities, and post-installation activities such as training and verification. A companion document (Kyiv Institutional Buildings Sector Energy Efficiency Program: Technical Assessment [PNNL 1997]) provides an assessment of the efficiency potential and investment requirements.

\subsection{Scope and Approach}

The purpose of this assessment is to provide options for implementing an energy efficiency program in the stock of state and municipal institutional buildings in Kyiv. This assessment contains two basic themes: 1) financing for installing energy efficiency measures and 2) processes for installing the efficiency measures. The measures and associated levels of investment have been identified in the above referenced technical assessment (PNNL 1997).

Institutional buildings are defined as nonresidential buildings owned and occupied by state and municipal organizations. General categories of institutional buildings are healthcare, education, and cultural.

Options for financing focus on the provision of capital and the repayment of loan(s). These include source(s) of capital, amounts of capital by source, terms that may apply to repayment of borrowed capital, and timing of the disbursement and repayment of the capital. Also addressed are institutional relationships that may apply to the disbursement and collection of funds.

The implementation sections of this report discuss options for the installation of efficiency measures. Factors addressed include management structure(s), contracting procedures, numbers and timing of installations, responsibilities of the implementing organizations, and alternatives for attaining persistence such as training, incentives, and reliance on community efforts. 
Risks that may apply to either financing or implementation are also characterized to specify impacts and mitigation strategies.

The intent of this assessment is to provide options and alternatives and to identify the associated positive and negative aspects. This information will be used to frame the discussions and decisions. Single actions or structures are presented if no alternatives exist because of requirements such as those that apply to World Bank procurements, or because of legal requirements in Ukraine that apply to the structure and repayment of loans.

\subsection{Report Organization}

The lending and implementation assessment is presented in the following chapters:

- Chapter 2 provides a summary of the technical assessment, which includes the physical characteristics of the institutional building stock, the types of applicable energy efficiency measures, the size of the cost-effective energy efficiency resource, and the associated level of investment.

- Chapter 3 presents secondary impacts of the proposed energy efficiency improvements including environmental, employment, and macro-economic.

- Chapter 4 provides a discussion of the lending structure required by Ukrainian law and financing and repayment options for an approximate $\$ 40$ million energy efficiency program.

- Chapter 5 provides a discussion of the implementation options including the relationships among organizations participating in the installation of the energy efficiency measures.

- Chapter 6 contains a discussion of the characterization of risk, potential impacts, and mitigation strategies.

- Chapter 7 presents a schedule of activities for implementing the project and installing the equipment/measures.

- Chapter 8 provides a discussion of the bidding/tendering process and describes the anticipated types and quantities of labor, equipment, and materials required and the procurement processes for obtaining the anticipated labor, equipment, and materials.

The appendices provide more detailed information. Appendix A contains the detailed technical data for institutional buildings. Appendix B provides a summary of Ukrainian regulations that apply to foreign loans and contains a copy of Decree No. 414 approved by the Cabinet of Ministers of Ukraine (1997) in May 1997. Appendix C provides a description of staff capabilities and budget for implementing the project. Appendix D contains bidding specifications for equipment and materials. 


\subsection{Study Participants}

Pacific Northwest National Laboratory (PNNL), one of DOE's five multi-program research laboratories, conducts a significant number of programs in the area of energy efficiency and integrated resource planning. PNNL's Advanced International Studies Unit (AISU) conducts research on global climate change and manages cooperative programs to transfer energy efficiency practices and technologies to other countries. PNNL provided technical and management oversight for this effort and contributed to all aspects of the analysis.

PNNL/AISU contracted with Tysak Engineering and the Agency for Rational Energy Use and Ecology (ARENA-ECO) to support the assessment activities. Tysak Engineering specializes in buildings efficiency assessments and implementation projects, with substantial experience in Eastern Europe. Tysak provided direct oversight for the technical analysis described in Chapter 2 and contributed to other aspects of the analysis.

ARENA-ECO is a Ukrainian nongovernmental, nonprofit organization dedicated to improving economic development and the environment through energy efficiency. ARENA-ECO provided the in-country coordination for the assessment and contributed to all aspects of the analysis. 


\subsection{Technical Assessment}

This chapter presents an overview of the results of the Kyiv Institutional Buildings Sector technical assessment (PNNL 1997). The chapter contains the following seven sections: 1) buildings sector description, 2) thermal consumption baseline, 3) list of efficiency measures considered, 4) description of technical assessment methodology, 5) efficiency potential assessment, 6) sensitivity analysis, and 7) investment requirements. Tables containing detailed results can be found in Appendix A. For a more complete description of the technical assessment, see the report Kyiv Institutional Buildings Sector Energy Efficiency Program: Technical Assessment (PNNL 1997).

\subsection{Buildings Sector Description}

Information on the stock of institutional buildings was collected for this analysis through a survey of institutional sector organizations. Not all organizations responded to the survey, and emphasis in the survey was placed on those organizations that were deemed to be most amenable to a buildings efficiency improvement program. Hence the buildings stock information contained in this report is not comprehensive, but includes the most important categories for the institutional buildings sector.

The primary descriptors used to characterize institutional buildings are function, age, and size (number of floors, also referred to as stories), each of which has an impact on thermal performance. The building age categories used are buildings constructed prior to 1958, those constructed from 1958 to 1980 , and those constructed after 1980 . These age groups conform roughly to periods with particular architectural styles and building codes that impact the thermal performance and applicability of energy efficiency measures (e.g., roof construction impacts the choice of roof or attic insulation as an efficiency measure). Building size categories were selected based on the available data. For institutional buildings, these are 1 to 2 story buildings, 3 to 4 story buildings, and buildings 5 stories and greater.

Institutional buildings are defined as nonresidential buildings owned and occupied by state and municipal government organizations. There are three types (subsectors) of institutional buildings: healthcare, education, and cultural. Each of these types is described below.

\section{Healthcare}

Healthcare buildings include only those buildings under the direction of the Municipal Department of Health and the Ministry of Health. There are a number of healthcare facilities under the direction of other organizations. The majority of buildings in the survey are owned by the Municipal Department of Health. 
The healthcare subsector is divided into four building types as follows:

- Hospitals. Hospitals provide in-patient care and medical services. In-patient hospitals are widely distributed by size with about one-third of the 160 buildings being 1 to 2 stories, 3 to 4 stories, and greater than 4 stories. In terms of floorspace, however, about two-thirds is in the $>4$ stories category, about half of which was built between 1958 and 1980, the other half after 1980. Hospitals are the largest subsector of healthcare buildings.

- Polyclinics. Polyclinics provide out-patient medical services. Polyclinics are widely distributed by both age and size. More than $45 \%$ of polyclinic floorspace is in the size category $>4$ stories and of post- 1980 construction. About $35 \%$ of floorspace is in the categories of 3 to 4 story polyclinics built between 1958 to 1980 and after 1980 . There are a total of 110 buildings in this category.

- Hospital Administration and Support Buildings. The healthcare sector includes a number of buildings that serve exclusively for administration and support activities. Though about $50 \%$ of the 69 hospital administration buildings are 1 to 2 story buildings and pre- 1958 construction, the largest concentration of floorspace ( $44 \%$ ) is found in newer (post-1958) buildings $>4$ stories.

- Other Healthcare Buildings. Though there are a large number of "other" healthcare-related buildings (136), they represent only $6 \%$ of the total healthcare floorspace. In addition, 64 buildings that are not primarily dedicated to healthcare have some floorspace used for healthcare activities. Again, this floorspace represents a small fraction of total floorspace in healthcare facilities. These buildings were not included in the analysis.

\section{Education}

The education subsector is divided into four building types. Kindergartens and schools are under the direction of the Municipal Department of Education. Higher education facilities and student hostels are under the direction of the Ministry of Education. A number of additional education buildings not included in this analysis are under the direction of several other organizations. A description of the four building types follows.

- Kindergartens. Public kindergartens serve a broader function in Ukraine and many other Eastern European countries than in the United States. After childbirth, mothers are allowed paid leave (currently 3 years, previously 1.5 years) to care for their child. An additional unpaid leave of the same duration is also available if they choose to remain in the home, with a guarantee of their old job when they return. Kindergartens thus serve a preschool/daycare function for children anywhere from 1.5 to 6 years of age. The kindergartens are generally small, with about 100-200 students, and are dispersed throughout the residential districts. In total there are approximately 600 state-owned kindergartens in Kyiv, all of them less than 5 stories high. More than half of the buildings and floorspace were built between 1958 and 1980 and are 1 to 2 stories high. The bulk of the remainder are also 1 to 2 stories and were built since 1980 . 
- Schools. Primary schools are also of small size and are distributed throughout the residential districts. The 389 school buildings are also less than 5 stories, with the majority (94\%) being 3 to 4 stories high. About half of the buildings were constructed between 1958 and 1980 . Along with buildings constructed since 1980 , there is also a sizable population of pre-1958 buildings. Schools are the largest single institutional building category in the survey, by area, comprising about 2.8 million square meters of floorspace.

- Higher Education. This building type includes technical institutes and universities. Of the 174 higher education buildings, more than $50 \%$ of buildings and floorspace were constructed in the period $1958-1980$. About $25 \%$ of the floorspace is in the post- 1980 category. This floorspace is accounted for by $19 \%$ of the buildings, reflecting a trend toward larger buildings in this period.

- Hostels. The Ministry of Education also operates a significant number of residential buildings for students. As with other higher education buildings, most hostels are greater than 5 stories, accounting for nearly $90 \%$ of total floorspace for hostels. About three-quarters of this floorspace was built from 1958 to 1980 .

\section{Cultural}

The cultural buildings included in the survey are owned by the Municipal Department of Culture. The cultural subsector is divided into two building types as follows:

- Theaters. Most of the 12 theaters included in the survey are of pre-1958 construction and have 3 to 4 stories. Pre-1958 buildings also make up $85 \%$ of floorspace.

- Art Galleries/Museums. Information was collected for 31 art galleries and museums. About $84 \%$ of these (26) are of pre-1958 construction.

The estimated number of institutional buildings and floorspace by building category and ownership is shown in Table 2.1. A more detailed listing is provided in Appendix A.

\subsection{Thermal Consumption Baseline}

Estimates of heat and hot water energy consumption by the institutional sector were based upon the estimates of building floorspace, type, vintage, and size, and estimates of specific energy consumption as a function of each of these building descriptors. Specific energy consumption estimates for the institutional buildings sector were derived primarily from design heat consumption for space heat, and from estimates of domestic hot water consumption by building type, expressed as a function of total heat demand. Estimates of heat and hot water consumption for the institutional sector are shown in Table 2.2 by building type and ownership subsector. Institutional sector energy use is dominated by education, which has the largest amount of floorspace. More detailed estimates of baseline energy consumption can be found in Appendix A, Table A.3. 
Table 2.1. Number and Floorspace of Institutional Buildings by Type, 1996

\begin{tabular}{||l|c|c||}
\hline \multicolumn{1}{|c|}{$\begin{array}{c}\text { Institutional } \\
\text { Building Type }\end{array}$} & $\begin{array}{c}\text { Number of } \\
\text { Buildings }\end{array}$ & $\begin{array}{c}\text { Floorspace } \\
\left(\mathbf{m}^{\mathbf{2}}\right)\end{array}$ \\
\hline Hospitals & 160 & 637,125 \\
\hline Polyclinics & 110 & 293,867 \\
\hline Administration & 69 & 92,245 \\
\hline Kindergartens & 600 & $2,804,268$ \\
\hline Schools & 389 & $1,312,326$ \\
\hline Higher Education & 174 & $1,228,765$ \\
\hline Hostels & 133 & 730,614 \\
\hline Theaters & 12 & 48,043 \\
\hline Art Galleries/Museums & 31 & 65,358 \\
\hline Total & 1,678 & $7,212,611$ \\
\hline
\end{tabular}

Table 2.2. Baseline Heat and Hot Water Energy Consumption by the Institutional Sector

\begin{tabular}{||l|l|c|}
\hline \multicolumn{2}{|c|}{ Institutional Buildings } & \multicolumn{1}{|c|}{$\begin{array}{c}\text { Baseline Energy Use } \\
\text { (thousand Gcal) }\end{array}$} \\
\hline \multicolumn{1}{|c|}{ Subsector } & \multicolumn{1}{|c|}{ Type } & 157 \\
\hline Healthcare & Hospitals & 59 \\
\cline { 2 - 3 } & Polyclinics & 16 \\
\cline { 2 - 3 } & Administration & 329 \\
\hline Education & Kindergartens & 470 \\
\cline { 2 - 4 } & Schools & 240 \\
\cline { 2 - 4 } & Higher Education & 154 \\
\cline { 2 - 3 } & Hostels & 10 \\
\hline Cultural & Theaters & 12 \\
\cline { 2 - 3 } & Art Galleries/Museums & 1,446 \\
\hline Institutional Sector & Total & \\
\hline
\end{tabular}

\subsection{Efficiency Measures Considered}

Forty-six energy conservation opportunities (ECOs) were evaluated for improving energy efficiency in the institutional buildings sector. Of these, 20 were determined to be applicable to one or more building types and were analyzed with respect to energy efficiency potential, cost, and availability on the Ukrainian market. Table 2.3 presents the estimated installed per unit costs for the efficiency measures. More detailed cost information is presented in Appendix A, Table A.4. 
Table 2.3. Efficiency Measures Considered and Cost Per Unit

\begin{tabular}{||l|c|c||}
\hline \multicolumn{1}{|c|}{ Efficiency Measure } & Unit & Cost (\$)/Unit \\
\hline Building Envelope & $\mathrm{m}^{2}$ & 25.17 \\
Exterior Side Walls & $\mathrm{m}^{2}$ & 27.94 \\
Roof Insulation & $\mathrm{m}^{2}$ & 11.38 \\
Attic Insulation & $\mathrm{m}^{2}$ & 7.59 \\
Basement Floor Insulation & $\mathrm{m}$ & 1.96 \\
Weatherstripping & each & 127 \\
Storm Windows & $\mathrm{m}^{2}$ & 43.17 \\
High-Performance Glass & $\mathrm{m}^{2}$ & 30.68 \\
Third Window Pane & each & 9.07 \\
Radiator Reflectors & & \\
\hline Air Handling & per fan & 203 \\
Ceiling Fans & $\mathrm{m} / \mathrm{hr}$ & 2.60 \\
Ventilation Heat Recovery & & \\
\hline Domestic Water Heating & bldg. & 2,190 \\
Hot Water Heat Exchanger & & \\
(Weighted Average) & bldg. & 3,147 \\
Storage Water Heater & each & 10.32 \\
Low-Flow Showerheads & each & 4.58 \\
Faucet Aerators & each & 135 \\
Hot Water Meters & $\mathrm{m}$ & 6.02 \\
Insulate Pipes & & \\
\hline Heating System & each & 2,960 \\
Building Heat Meters & each & 9,018 \\
Retrofit Heating System & & 27.58 \\
(Weighted Average) & & \\
Radiator Balancing Valves & & \\
\hline
\end{tabular}

\subsection{Technical Assessment Methodology}

The technical assessment methodology consists of two parts: the engineering analysis and the economic analysis. The engineering analysis is used to evaluate the energy savings potential of individual ECOs and packages of ECOs. The economic analysis is then used to evaluate the cost effectiveness of individual ECOs and packages of ECOs. Two subsections (2.4.1 and 2.4.2) describe the engineering and economic analysis methods, respectively. 


\subsubsection{Engineering Analysis}

The engineering analysis methodology differs based on the type of efficiency measure being analyzed: building envelope measures, water heating measures, heating system measures, and heat recovery ventilation measures. The analysis for each of these measure types is discussed below.

\section{Analysis of Building Envelope Measures}

The ASEAM5 (A Simplified Energy Analysis Method, Version 5) computer program was used in this analysis to model heat losses in buildings based on procedures recommended by the American Society for Heating, Refrigeration, and Air Conditioning Engineers (ASHRAE). The program calculates the peak building energy demands and annual energy consumption based on weather conditions in a given location. This computer program utilizes a bin-type TMY (typical meteorological year) weather

file created from hourly weather data collected over a long period. The output reports include effects of other factors on building heat loads, such as occupancy schedule, lighting, appliance usage, insulation, etc., which helps determine the most effective energy conservation measure for each building type.

Baseline and post-measure installation heat and hot water energy consumption were calculated for each measure and each building type, the difference being the efficiency improvement. The development of the baseline building heating loads for each institutional building type required making several assumptions. The most important assumptions were infiltration rates, internal temperatures in different locations, and occupancy and equipment schedules. These assumptions were based on recommended values, previous experience, and information gathered during the energy audit of the representative buildings for each group.

In the modeling of each ECO, only the pertinent value describing the given $\mathrm{ECO}$ was changed in the model. Insulation of walls, ceilings, and floors was modeled by lowering U-values. Weatherstripping was modeled by lowering the infiltration rate. Modeling of triple-pane and storm windows was accomplished by lowering U-values.

\section{Analysis of Water Heating Measures}

Efficiency improvement calculations for low-flow showerheads and faucet aerators were based on statistical information regarding the use of hot water in Ukraine, statistical information on hot water use by purpose (dishwashing, shower, laundry, etc.), and manufacturers' performance information. Calculation of efficiency improvements obtainable by insulating the hot water pipes in unconditioned spaces is based on lowering heat losses through additional pipe insulation with improved R-value or replacement of existing insulation with high-performance materials. Because of the limited nature of this effort, exact length and sizes of pipes could not be determined, but rather were estimated for each building group based on typical plumbing designs. 


\section{Analysis of Building Heating System}

All ECOs in this category provide improved energy management in the building and assume that outdoor temperature reset control is installed in each substation of the central district heating system.

Installation of temperature control devices in conjunction with installation of energy consumption metering provides building occupants/owners with an incentive to reduce energy consumption. The use of a programmable thermostat also improves the use of setback during unoccupied periods. The combination of better energy management and distribution within the building and the ability of motivated occupants to lower energy consumption results in two effects:

- Room temperature is kept at the lowest possible acceptable (comfortable) level.

- Windows are opened only to maintain acceptable indoor air quality and not for temperature control.

The computerized calculations used for the building heating system efficiency improvements were also derived from procedures recommended by ASHRAE. For each measure, the baseline and postmeasure installation heat loss were both calculated. The difference between the two heat loss values is the energy use reduction. For each ECO analyzed, the temperatures and infiltration rates were estimated based on performance of the proposed equipment and expected occupant behavior. In general, more accurate equipment and motivated occupants will produce lower temperatures and lower infiltration rates. The temperatures were not assumed to drop below acceptable comfort limits.

\section{Analysis of Ventilation Heat Recovery Measures}

Although none of the ventilation energy efficiency measures were considered for application, evaluation of several measures was performed. The energy saving calculations developed for the heat recovery applications were again derived from procedures recommended by ASHRAE. Inputs to the calculations include properties and mass flow of media from which the waste heat is recovered and manufacturers' performance characteristics for the heat recovery equipment.

\subsubsection{Economic Analysis Method}

This section provides a discussion of the economic analysis metrics, the economic assumptions, and the approach employed to assess the economic performance of the efficiency measures.

\section{Analysis Metrics}

The ECOs described in the previous section were analyzed using a number of economic methods or "metrics" to evaluate the attractiveness of each option. A number of economic metrics are commonly used to evaluate measure performance: simple payback, present and net present value (NPV), and internal rate of return (IRR). These metrics are described below. 
Simple Payback. The most basic economic analysis metric is the simple payback period, which in its simplest form is calculated by dividing the installed cost of the ECO by the value of the annual energy savings. The simple payback period is the number of years required for the savings resulting from an investment in energy efficiency to offset the cost of the investment. The lower the payback period, the more attractive the investment.

In many analysis situations, this metric is too simplistic to be of much use. ECOs with future costs may be overvalued if these costs are not accounted for. Escalating fuel prices will also undervalue an ECO. Simple payback does not enable ready comparison for measures having different useful lifetimes. This method also does not account for the time value of money and may not be readily comparable with other investments using more sophisticated measures of value. Despite the many shortcomings of this method, it is frequently used along with first cost to evaluate the attractiveness of measures.

Present and Net Present Value. A Hryvna today is worth more than a Hryvna tomorrow for two principal reasons: general price inflation and the time value of money. Based on general price inflation, the purchasing power of a Hryvna declines over time, and because the true value of money lies in what it is capable of purchasing, inflation causes its value to decline. The time value of money refers to the fact that even in the absence of general price inflation, money received sooner is preferred to money received later.

It is this preference for consuming sooner rather than later that leads to the existence of positive rates of interest, even in the absence of price-level inflation. Individuals and firms are willing to pay a premium to obtain goods and services sooner rather than later, and the premium they are willing to pay is the "real rate of interest." The market or "nominal" rate of interest is the real rate plus the rate of inflation (this is a slight simplification). As an example, 100 Hryvna received 2 years from today is worth $82.64 \mathrm{Hryvna}$ today, assuming a 10\% nominal rate of interest. Conversely, $82.64 \mathrm{Hryvna}$ invested today at a $10 \%$ per annum annual nominal rate of interest yields 100 Hryvna 2 years later.

The costs and benefits of an efficiency investment occur at different periods in time, which must be accounted for in the analysis. A metric for reflecting this fact is net present value, where the present value of all the costs of an ECO is compared to the present value of all the benefits of the ECO. The difference between the two, NPV, is a measure of the cost-effectiveness of an ECO. A negative NPV means the costs of an ECO outweigh its benefits, while a positive NPV means that the benefits are greater than the costs. The higher the NPV, the better. The formula for calculating the NPV is:

$$
N P V=\sum_{t=1}^{N} \frac{R_{t}}{(1+d)^{t}}-C
$$

where: $t=$ year

$$
\begin{aligned}
\mathrm{R} & =\text { annual return } \\
\mathrm{d} & =\text { discount rate } \\
\mathrm{C} & =\text { capital outlay }
\end{aligned}
$$


Internal Rate of Return. The IRR is the interest rate that equates the present value of the expected future cash flows or receipts to the initial capital outlay. The formula for calculating the IRR is:

$\mathrm{IRR}=\mathrm{r}$ such that:

$$
\sum_{t+1}^{N} \frac{R_{t}}{(1+r)^{t}}-C=0
$$

where: $\mathrm{t}=$ year

$\mathrm{R}=$ annual return

$\mathrm{r}=$ interest rate

$\mathrm{C}=$ capital outlay

The difference between the NPV and IRR is the discount rate (d) and interest rate (r). In the case of IRR, the formula is solved for the interest rate ( $r$ ) where the benefits minus the costs equal zero. The IRR is often used to screen and rank alternative investments--in general, the higher the IRR, the better. In the case of this analysis, an IRR of $20 \%$ or greater is deemed acceptable before accounting for risks, and the minimum acceptable IRR after risks is the discount rate of $10 \%$.

In this analysis the IRR is computed only for those ECOs where a conventional cash flow stream exists and where the NPV is positive. Other cases may lead to multiple solutions or no solution. Conventional cash flow is the net cash flow stream, which begins with a disbursement of funds followed by a stream of savings.

Economic Assumptions. Two types of economic analysis methods typically used are nominal and real. The main difference between the two is the presence or absence of inflation, respectively. In a nominal analysis, the value of energy savings in 1997 is expressed in 1997 Hryvna, the value of energy savings in 1998 is expressed in 1998 Hryvna, and so on. The nominal value of the energy savings continues to increase because of inflation and the general level of prices. A real analysis expresses all money values in constant terms by removing the effects of inflation. In the case of this analysis, all values are expressed in 1996 currency values.

The implication of using a real analysis is the need to calculate a real discount rate to reflect the time value of money, which is the "real" interest rate after the effects of inflation have been removed. For the purposes of this analysis, a simplification is used whereby the discount rate is calculated as the nominal interest rate minus the expected rate of inflation.

Basic economic assumptions are provided below.

- nominal discount rate $-16 \%$

- inflation rate $-6 \%$ 
- real discount rate $-10 \%$

- analysis period - 15 years.

\subsection{Efficiency Potential Assessment}

This section provides the energy and economic assessment of the 20 energy efficiency measures (described in Section 2.3) considered for the analysis. The method employed to assess the efficiency potential for the institutional sector consisted of three steps:

1. Screen the individual measures by simple payback; measures having a simple payback of less than 5 years were retained for additional analysis.

2. Combine the measures to identify interactive effects to avoid double counting the efficiency potential and to deselect measures that reduced the payback of selected bundles for individual building types.

3. Evaluate the measure bundles and applicable individual measures for each building type to estimate efficiency potential.

The following group of four space-heating measures having an interactive effect were selected for application:

- windows and door weatherstripping

- reflectors behind radiators

- ceiling fans

- substation-level controls.

Depending on building type, a subset of these items was selected based upon their combined performance.

The following three measures, which did not exhibit interactive effects, were also selected for application depending on their performance:

- hot water heat exchangers

- low-flow showerheads

- aerators on faucets. 
In all cases, building heat meters are included.

Table 2.4 shows the cost-effective institutional sector efficiency potential by building type. Additional detail is contained in Appendix A, Table A.5.

Table 2.4. Institutional Sector Efficiency Potential

\begin{tabular}{||l|c|c|c|c||}
\hline $\begin{array}{c}\text { Institutional } \\
\text { Building Type }\end{array}$ & $\begin{array}{c}\text { Baseline Energy Cons. } \\
\text { (thousand Gcal) }\end{array}$ & $\begin{array}{c}\text { Efficiency Potential } \\
\text { (thousand Gcal) }\end{array}$ & $\begin{array}{c}\text { Percent } \\
\text { Savings (\%) }\end{array}$ & $\begin{array}{c}\text { IRR } \\
\text { (\%) }\end{array}$ \\
\hline Hospitals & 157 & 40 & 25.8 & 27.8 \\
\hline Polyclinics & 59 & 16 & 27.2 & 24.4 \\
\hline Administration & 16 & 4 & 26.2 & 16.4 \\
\hline Kindergartens & 329 & 86 & 26.2 & 31.7 \\
\hline Schools & 470 & 129 & 27.4 & 29.1 \\
\hline Higher Education & 240 & 64 & 26.5 & 31.6 \\
\hline Hostels & 154 & 34 & 22.0 & 25.4 \\
\hline Theaters & 10 & 3 & 28.7 & 26.8 \\
\hline $\begin{array}{l}\text { Art } \\
\text { Galleries/Museums }\end{array}$ & 12 & 2 & 19.6 & 12.9 \\
\hline Total & 1,446 & 378 & 26.2 & 29.2 \\
\hline
\end{tabular}

\subsection{Sensitivity Analysis}

The sensitivity of the economic analysis to any particular input variable can be assessed by holding all other exogenous variables constant while the variable of interest is changed. In this fashion, the value of any particular variable at which the investment becomes unattractive (i.e., the IRR becomes less than $10 \%$ ) can be determined. This will be referred to as the switching value.

The switching analysis was carried out with respect to two variables: energy savings and installed costs for efficiency measures. The switching values, expressed either as the percentage of the energy savings below the estimated value, or as the percentage of the installed costs above the estimated value, for which IRR becomes less than $10 \%$, is presented in Table 2.5 .

In the case of hospitals, the energy savings would have to fall to $40 \%$ of the estimated value for the IRR to drop below $10 \%$ (i.e., the energy savings would have to be $10.3 \%$ instead of $25.8 \%$ of baseline energy use), or the installed cost would have to increase by $240 \%$. The institutional building types most sensitive to realized efficiency improvements or installed costs of efficiency measures are cultural buildings and hospital administration buildings. 
Table 2.5. Internal Rate of Return Switching Value for Energy Savings and Installed Costs - Institutional Buildings

\begin{tabular}{|l|c|c|}
\hline \multicolumn{1}{|c|}{ Type } & Energy Savings (\%) & Installed Costs (\%) \\
\hline Hospitals & 40 & 240 \\
\hline Polyclinics & 45 & 220 \\
\hline Hospital Admin. & 70 & 160 \\
\hline Kindergartens & 35 & 280 \\
\hline Schools & 40 & 260 \\
\hline Higher Education & 35 & 280 \\
\hline Hostels & 45 & 220 \\
\hline Theaters & 45 & 240 \\
\hline Art Galleries/Museums & 80 & 120 \\
\hline
\end{tabular}

\subsection{Investment Requirements}

This section presents building-level investment requirements to procure the efficiency resources presented in Table 2.4. Investment levels are expressed in terms of both investment per building and investment per square meter of floorspace. The per-square-meter estimates are multiplied by the building stock estimates to provide an overall sector investment requirement. Total investment requirements are presented in Table 2.6. Total investment requirements are presented in more detail in Appendix A, Table A.6.

Table 2.6. Institutional Buildings Sector Investment Requirements

\begin{tabular}{||l|c|c|c|}
\hline \multirow{2}{*}{$\begin{array}{c}\text { Institutional Building } \\
\text { Type }\end{array}$} & \multicolumn{3}{c|}{ Investment Requirements (\$) } \\
\cline { 2 - 4 } & Per Building & Per Square Meter & Total \\
\hline Hospitals & 21,719 & 5.45 & $3,475,019$ \\
\hline Polyclinics & 14,143 & 5.29 & $1,555,709$ \\
\hline Administration & 8,309 & 6.21 & 573,290 \\
\hline Kindergartens & 11,771 & 5.38 & $7,062,886$ \\
\hline Schools & 24,987 & 3.47 & $9,719,980$ \\
\hline Higher Education & 29,581 & 3.92 & $4,820,270$ \\
\hline Hostels & 23,994 & 4.37 & $3,191,160$ \\
\hline Theaters & 24,266 & 5.32 & 255,545 \\
\hline Art Galleries/Museums & 29,844 & 6.08 & 397,093 \\
\hline Total & 25,981 & 4.31 & $31,050,952$ \\
\hline
\end{tabular}


Investment levels are expressed both in terms of investment per building and investment per square meter of floorspace. The per-square-meter estimates are multiplied by the building stock estimates to provide an overall sector investment requirement. These values should be taken as an upper bound, as they are based on the assumption of $100 \%$ penetration of the efficiency measure packages into the building stock. In reality, not all existing buildings would be susceptible to retrofit.

In the institutional buildings sector, the per-square-meter costs range from a low of $\$ 3.47$ for primary/secondary schools to a high of about $\$ 6.08$ for houses of culture. The single largest category for investment potential is schools at $\$ 9.7$ million, followed by kindergartens at $\$ 7.1$ million. The potential investment level for residential buildings is nearly $\$ 300$ million compared to $\$ 31.1$ million for the institutional buildings considered in this analysis. 


\subsection{Impacts Assessment}

The buildings efficiency improvement program will have potential additional impacts, primarily in two categories: economic and environmental. These include impacts on employment, energy security, air pollutant emissions levels, worker health and safety during building renovation activities, and indoor air quality as a result of building renovations. These potential impacts are summarized below. A more complete description of the impacts assessment can be found in the technical assessment document for this project (PNNL 1997).

\subsection{Economic Impacts}

The potential economic impacts are substantial for buildings efficiency programs in Kyiv and Ukraine. The estimated economic and employment impacts are presented in Table 3.1.

An efficiency program would have direct and positive employment impacts for retrofit installation work. This analysis assumes the ratio of Ukrainian to Western labor ranges from 5:1 to 8:1, depending on the efficiency measure. While it is not clear to what extent energy retrofit services exist in Kyiv, such capabilities are likely to develop. The resulting employment impacts are estimated at 64 full-time equivalents (FTEs) for the second through fifth years of the project. It is expected that domestic suppliers and manufacturers of equipment will also develop, but associated employment is not estimated.

The reduction in energy expenditures translates directly into reductions of state and municipal expenditures. Budgetary expenditures are projected to decrease by $\$ 9$ million per year in the last year of the project. This is estimated to result in a redirection of $\$ 5.8$ million in annual expenditures for fuel imports.

Although a residential sector program was not examined in detail, the burden of excessive fuel consumption is also felt by residential consumers. The International Energy Agency (IEA) estimates that a typical urban family of four pays as much as one-third of wage earnings for the energy bill (IEA 1996). Reductions in energy consumption that are translated into reductions in energy-related expenditures would have a substantial positive impact on disposable income. It is estimated that residential sector energy bills could be reduced by as much as $2.5 \%$. 
Table 3.1. Secondary Impacts

\begin{tabular}{|c|c|c|c|c|c|c|}
\hline & 1998 & 1999 & 2000 & 2001 & 2002 & Annual - \\
\hline \multicolumn{7}{|l|}{ Budget Reductions } \\
\hline Municipal Dept. of Health (\$) & 266,411 & 543,478 & 831,521 & $1,130,869$ & $1,441,858$ & $1,441,858$ \\
\hline Municipal Dept. of Education (\$) & 945,421 & $1,928,658$ & $2,950,847$ & $4,013,152$ & $5,116,769$ & $5,116,769$ \\
\hline Ministry of Education (\$) & 429,093 & 875,349 & $1,339,284$ & $1,821,427$ & $2,322,319$ & $2,322,319$ \\
\hline Municipal Dept. of Culture (\$) & 23,314 & 47,560 & 72,768 & 98,964 & 126,179 & 126,179 \\
\hline Total $(\$)$ & $1,664,238$ & $3,395,046$ & $5,194,420$ & $7,064,412$ & $9,007,125$ & $9,007,125$ \\
\hline \multicolumn{7}{|l|}{ Emissions Reductions (tonnes) } \\
\hline $\mathrm{NO}_{\mathrm{x}}$ & 66 & 133 & 199 & 266 & 332 & 332 \\
\hline $\mathrm{SO}_{\mathrm{x}}$ & 46 & 93 & 139 & 185 & 232 & 232 \\
\hline $\mathrm{CO}_{2}$ & 17,085 & 34,171 & 51,256 & 68,342 & 85,427 & 85,427 \\
\hline \multicolumn{7}{|l|}{ Domestic Employment (FTEs) ${ }^{(\mathrm{b})}$} \\
\hline Direct (measure installation) & 3 & 63 & 63 & 63 & 63 & \\
\hline Indirect (materials manufacture) & * & $*$ & * & * & * & * \\
\hline \multicolumn{7}{|l|}{ Fuel Import Reductions ${ }^{(\mathrm{c})}$} \\
\hline \begin{tabular}{|l} 
Natural Gas (thousand $\mathrm{m}^{3}$ ) \\
\end{tabular} & 11,452 & 22,904 & 34,357 & 45,809 & 57,261 & 57,261 \\
\hline Mazut (tonnes) & 16,118 & 32,236 & 48,354 & 64,472 & 80,590 & 80,590 \\
\hline Natural Gas (\$) & 950,531 & $1,901,062$ & $2,851,593$ & $3,802,123$ & $4,752,654$ & $4,752,654$ \\
\hline Mazut (\$) & 218,744 & 437,489 & 656,233 & 874,978 & $1,093,722$ & $1,093,722$ \\
\hline Total Fuel (\$) & $1,169,275$ & $2,338,551$ & $3,507,826$ & $4,677,101$ & $5,846,376$ & $5,846,376$ \\
\hline \multicolumn{7}{|c|}{$\begin{array}{l}\text { (a) } \mathrm{NO}_{\mathrm{x}} \text { and } \mathrm{SO}_{\mathrm{x}} \text { emission factors from Ekono Energy (1996). } \mathrm{CO}_{2} \text { emission factors from DOE (1995). } \\
\text { (b) Full-time equivalents. } \\
\text { (c) Fuel import reductions estimated from energy savings using estimated transmission } / \text { distribution losses of } 20 \% \text {, and average boiler } \\
\text { efficiency of } 88 \% \text {. Natural gas savings converted from } \mathrm{Gcal} \text { to cubic meters using } 7,975 \mathrm{kcal} / \mathrm{m}^{3} \text { (Kievenergo data) (JTC 1996), and } \\
\text { mazut savings converted from Gcal to tonnes using } 7,000 \mathrm{kcal} / \mathrm{kg} \text {. Estimated price of natural gas, } \$ 83 / \text { thousand } \mathrm{m}^{3} \text {. Estimated price } \\
\text { of mazut, } \$ 95 / \text { tonne. } \\
\text { * Domestic manufacture of equipment and materials is expected, but an estimate of the types and quantities of materials and associated } \\
\text { employment impacts has not been made. }\end{array}$} \\
\hline
\end{tabular}




\subsection{Environmental Impacts}

This assessment is driven by World Bank and Ukrainian requirements for environmental assessments related to buildings efficiency improvement programs. The project requires a category " $B$ " Environmental Mitigation Plan as defined in the Bank's Operational Directive on Environmental Assessment, O.D. 4.01 (World Bank 1991). The assessment has also been performed in accordance with the requirements of the Ukrainian Ministry of Environmental Protection and Nuclear Safety (Law of Ukraine 1991, Law of Ukraine 1992). Specific regulations are discussed by topic area below.

\subsubsection{Emissions Impacts}

The potential investment program is expected to reduce heat demand in buildings, and hence energy consumption and emissions. The magnitude of the emissions reduction is a function of the heat demand reduction, the net heat production and distribution efficiency, and the emissions rates of the district heating boilers. As discussed above, precisely estimating the actual emissions reduction is difficult. However, a reasonable approximation can be made using estimated average emission factors and system performance. The assumptions used in this analysis are presented in Table 3.1.

Total emissions reductions by year as a result of the project are presented in Table 3.1. Projections indicate that after the year $2020, \mathrm{NO}_{\mathrm{x}}$ emissions would be reduced by 332 tonnes, $\mathrm{SO}_{\mathrm{x}}$ emissions would be reduced by 232 tonnes, and $\mathrm{CO}_{2}$ emissions would be reduced by 85,427 tonnes annually.

\subsubsection{Health and Safety}

Both the World Bank and Ukraine have health and safety guidelines for construction activities. Of primary concern is the potential for exposure of workers and occupants to asbestos, which is sometimes used in building materials such as insulation. Exposure to airborne asbestos particles poses a known health risk. In Ukraine, asbestos is used primarily to produce asbestocement, which may be used as a material for different types of pipes and ducts and for roofing tiles. Asbestocement air ducts may be used in ventilation exhaust systems. However, Ukrainian law (State Committee of Ukraine on Affairs of Urban Development and Architecture 1996, SNiP No. 2.04.05-91) prohibits the use of asbestocement air ducts in input ventilation systems. It has been determined that asbestos is not commonly used as an insulating material. The potential investment program does not contain components related to the ventilation system. Hence, the potential to encounter asbestos in renovation projects is negligible; however, it is recommended that the presence of asbestos and its potential disturbance be addressed in the audit of individual buildings.

An additional health issue that may be worthy of further consideration relates to the use of industrial waste materials in concrete used to manufacture prefabricated panels for high-rise apartment construction. Since the early 1960 s, these panels were manufactured at industrial facilities along the Dnieper River. In some cases industrial residues from the Donets Basin were used as aggregate in these panels (TACIS 1994). The use of such residues is now prohibited due to the potential for high content of heavy 
metals in the waste. However, little publicly available information has been located on the health hazards associated with the use of these panels in existing buildings.

Positive health impacts can be expected due to improved temperature control in buildings. The improved environment may reduce the number of occupant sick days and improve productivity; however, it would be extremely difficult to quantify such impacts, and no attempt to do so is made here.

\subsubsection{Indoor Air Quality}

Ukrainian sanitary norms regulate maximum permissible concentrations of harmful substances in ambient (outdoor) air. Under regulations of the Ministry of Health, maximum concentrations for indoor air of residential and institutional buildings must not exceed established maximum permissible concentrations for ambient air. To comply with these regulations, Ukrainian law (State Committee of Ukraine on Affairs of Urban Development and Architecture 1996, SNiP 2.04.05-91) requires that the building ventilation system be designed appropriately, and that the heating system design must account for heat losses due to the warming of ventilation air. These heat losses are normally calculated on the basis of one air change per hour, though some buildings may be designed for greater air change rates. The World Bank requires a minimum ventilation rate of 0.5 air changes per hour.

Actual existing ventilation rates in Ukraine are difficult to quantify. In institutional buildings, ventilation systems are often inoperable. Because of high infiltration rates, however, indoor air quality is generally not a problem. Because some efficiency measures are expected to reduce infiltration, it will be necessary to ensure that adequate ventilation is maintained.

The potential for insufficient ventilation will be addressed for individual buildings at the time of the building audit to determine applicable efficiency measures. In addition, the monitoring and verification activities should include a component to monitor air quality in selected buildings.

\subsubsection{Soil Contamination}

The potential investment program is not expected to have a significant impact on soil contamination. None of the materials expected to be used in the program are, or contain, contaminants. World Bank directives also prohibit investment in buildings with soil contamination.

Existing soil contamination may be of concern in Kyiv due to the location of past or present industrial activities near residential and commercial areas. In addition, Kyiv is located in an area affected by the 1986 Chornobyl nuclear power plant explosion, which spewed radioactive materials into the atmosphere. This contamination is no longer considered to pose a hazard, but it is recommended that the potential for disturbance of contaminated soil be addressed during the audit of individual buildings. 


\subsubsection{Ozone Depleting Substances}

In compliance with the Montreal Protocol ${ }^{(a)}$ (signed by Ukraine on February 18, 1988, and ratified by the Ukrainian Parliament on September 20,1988), the Cabinet of Ministers of Ukraine issued Decree \#1274 (Cabinet of Ministers of Ukraine 1996a) approving a program for stopping the production and use of ozone depleting substances (ODS) in Ukraine. While ODS regulated by the Montreal Protocol ${ }^{(\mathrm{a})}$ are not manufactured in Ukraine, they are used in almost every sector of the economy.

Ukraine will receive financial assistance, partly financed by a Global Environmental Facility grant of $\$ 26.5$ million, to implement projects on the conversion of ODS-using enterprises. The grant is conditioned on the implementation of licensing procedures for the import of ODS and ODS-containing equipment and materials, including foam insulation manufactured with chlorofluorocarbon (CFC) foaming agents such as HCFC-11. The total number of licenses will gradually be reduced as required by the London amendments to the Montreal Protocol. ${ }^{(a)}$

The World Bank also restricts the use of ODS in particular foam insulations manufactured with CFCs or their derivatives. To comply with these regulations, all tender documents for this project will stipulate that foam insulation materials shall not be manufactured using CFCs.

(a) The 1997 Montreal Protocol on Substances that Deplete the Ozone Layer, as adjusted and amended by meetings in London in June 1990, in Copenhagen in November 1992, and in Vienna in December 1995; sponsored by the Ozone Secretariat, United Nations Environmental Program. 


\subsection{Lending Structure}

This chapter presents options for the financing/lending structure. Though the financing/lending structure and the implementation/installation structure are related, and hence need be considered together, they are discussed separately to reduce complexity. The discussion of the implementation/ installation structure is presented in Chapter 5 . The preference for any given option in one activity may affect the preference for an option within another activity and/or the assignment of responsibility to a particular organization.

Steps in the lending and implementation processes are shown below. The steps shown in italics are the major activities in the financing/lending process; these are the loan disbursement, payments, collection of payments, and loan service. The italicized steps are discussed in this chapter.

Step 1. designate loan agent(s)

Step 2. specify target buildings

Step 3. procure/designate installation agent(s) and supplier(s)

Step 4. installation audit and measure specification

Step 5. installation

Step 6. installation acceptance

Step 7. operations and maintenance (O\&M) training

Step 8. pay installer

Step 9. collect payments

Step 10. service loan

Step 11. verification and incentives.

To the extent possible, the discussions in Chapters 4 and 5 present options with the pro's and con's of each. In so doing, the intent is to provide a framework for discussions among the participating organizations and to avoid making a specific recommendation whenever possible. Exceptions do occur, and single recommendations are provided when options are limited by a regulatory or legislative act, or alternatives are clearly not workable. Last, the examination is not comprehensive and is intended to generate additional discussion of the options and to identify additional options. 
It is anticipated that the potential loan will be directed to the retrofit of buildings belonging to the following organizations:

- Two state organizations under the purview of the Ministry of Finance

- Ministry of Health (healthcare buildings)

- Ministry of Education (higher education buildings)

- Two municipal organizations under the purview of the Municipal Department of Finance

- Municipal Department of Education (kindergartens and primary/secondary education buildings)

- Municipal Department of Culture

Thus, there are two to four owning organizations, depending upon how they are defined, for determining the lending and repayment structure.

This chapter is organized into three subsections. The first, Lending Structure and Management Responsibility, provides options for assigning ultimate responsibility for the acceptance and repayment of the potential loan. The second, Loan Disbursement, provides options for the disbursement of the loan by the recipient organization(s) to the suppliers and installers of equipment and materials. The third section provides a discussion of the collection and payment options to service the potential loan.

\subsection{Lending Structure and Management Responsibility}

The lending structure consists of the organization(s) ultimately responsible for accepting and servicing the loan. The structure has been defined according to Decree $\# 414$ of the Cabinet of Ministers of Ukraine, "On Streamlining Attraction and Use of Foreign Credits the Repayment of Which is Guaranteed by the Cabinet of Ministers of Ukraine, Improvement of the System of External Financial Resources Attraction and External State Debt Servicing." The text of the Decree is located in Appendix B. Figure 4.1 depicts the financial management structure according to Decree \#414.

The Ministry of Economy is assigned overall responsibility for the project and reports to the Cabinet of Ministers, who have provided the sovereign guarantee for the loan. After the Cabinet of Ministers approves the final report on project implementation, the Vice Prime Minister forwards it to the World Bank.

Day-to-day responsibility is delegated to an Organization Responsible for the Project that provides oversight for a Project Implementation Organization (PIO). An Interdepartmental Commission works directly with the Organization Responsible for the Project to provide assistance, guidance, and oversight for the PIO through the Organization Responsible for the Project. 


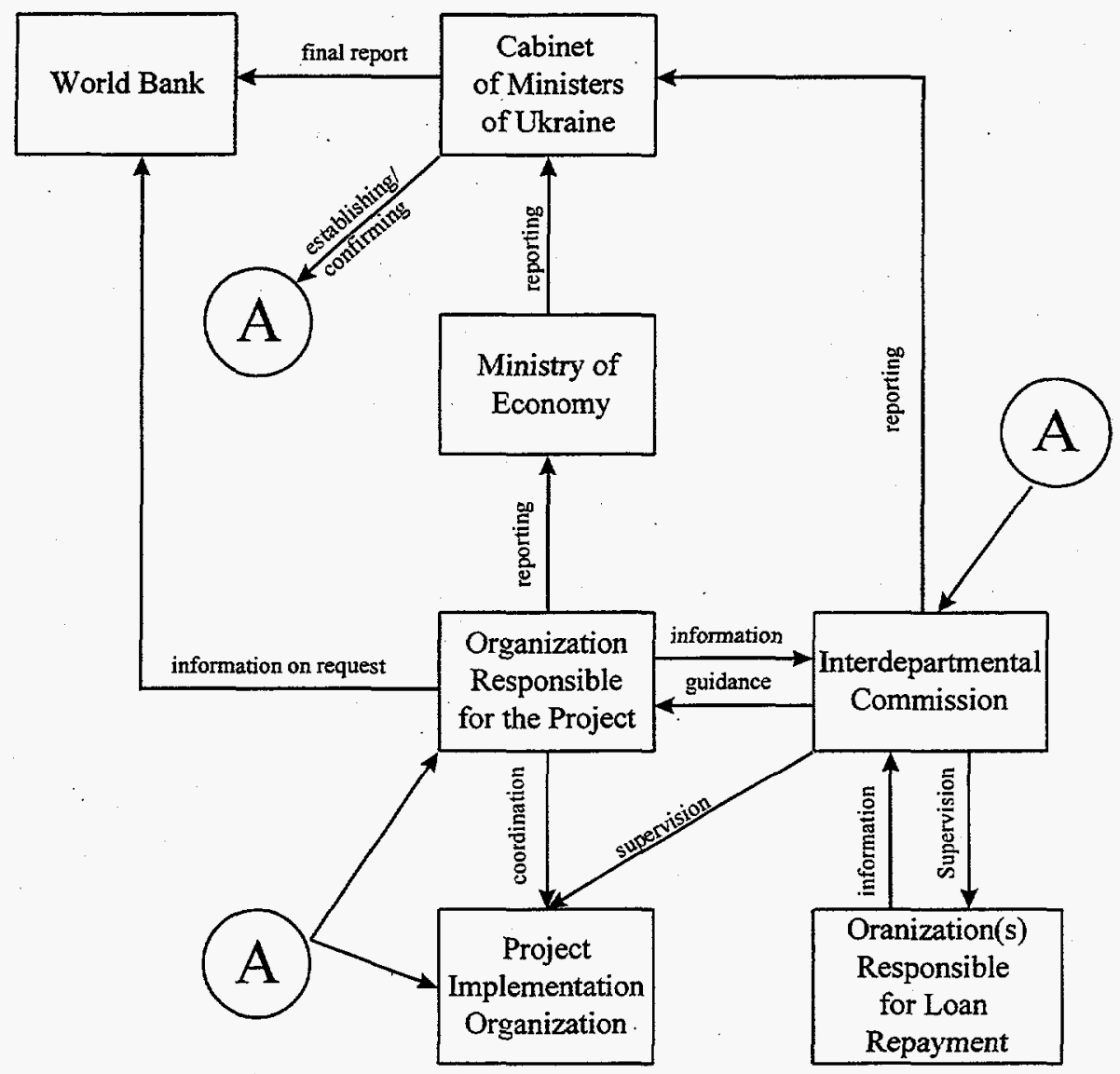

Figure 4.1. The Financial/Lending Management Structure According to Decree \#414 (Note: the A's connect to each other)

The Interdepartmental Commission is created by the Cabinet of Ministers for the purpose of supervising fulfillment of the agreement with the World Bank. The Interdepartmental Commission is responsible for ongoing supervision of project implementation and reports to the Vice Prime Minister of Ukraine who is in charge of economic matters. The two to four organizations identified above that "own" the buildings that are the subject of efficiency improvements and are responsible for repaying the loan interact with the Interdepartmental Commission.

As far as reporting, the Decree stipulates that the Ministry of Economy provides to the Cabinet of Ministers a quarterly report containing summary information on all ongoing projects financed by the World Bank and proposals to ensure timely implementation of projects. For the Kyiv Institutional Building Assessment (KIBA) project, the Organization Responsible for the Project provides necessary information and reports to the Ministry of Economy on a quarterly basis. The Organization Responsible for the Project also provides information to the World Bank regarding project implementation. 
The Interdepartmental Commission may be composed of representatives from the:

- Cabinet of Ministers

- World Bank

- State Committee for Energy Conservation

- Ministry of Finance

- Ministry of Economy

- National Agency for Reconstruction and Development

- Export/Import Bank of Ukraine (Eximbank)

- Kyiv Municipal Budget Authority

- Kyiv Municipal Department of Health

- Ministry of Education

- Kyiv Municipal Department of Education

- Kyiv Municipal Department of Culture.

Some of the above organizations may be more actively involved than others in the Interdepartmental Commission's activities - perhaps designated as voting members and observers. Also, the Deputy Head of the Organization Responsible for the Project becomes Head of the Interdepartmental Commission.

From several candidate organizations, the Cabinet of Ministers will decide which organization will be responsible for the project. A list of candidate organizations with pro's and con's of each is provided in Table 4.1. 
Table 4:1. Options for Organization Responsible for the Project

\begin{tabular}{|c|c|c|}
\hline Assignee/Description & Pro's & Con's \\
\hline Ministry of Finance & Maintains high level of accountability. & $\begin{array}{l}\text { The Ministry is not close to the process. } \\
\text { This could be considered a diversion of } \\
\text { resources and responsibility. }\end{array}$ \\
\hline $\begin{array}{l}\text { State Committee for Energy } \\
\text { Conservation }\end{array}$ & $\begin{array}{l}\text { Assigns responsibility formally within } \\
\text { the government, which potentially } \\
\text { increases accountability and lowers } \\
\text { risk. } \\
\text { Centralizes function thereby providing } \\
\text { consistency and reducing duplication. } \\
\text { Closely involved in energy efficiency } \\
\text { and well aware of the processes in this } \\
\text { field. }\end{array}$ & $\begin{array}{l}\text { May pose a bias for portraying the } \\
\text { success of the project. }\end{array}$ \\
\hline $\begin{array}{l}\text { Kyiv Municipal District Heating } \\
\text { Company }\end{array}$ & $\begin{array}{l}\text { Has an accounting system that can be } \\
\text { modified for this purpose } \\
\text { Has direct customer contact and } \\
\text { knowledge of the customer base. }\end{array}$ & $\begin{array}{l}\text { Tendency for supply-side focus. } \\
\text { Low level of interest in making the } \\
\text { project successful, because it would } \\
\text { reduce revenues as a result of } \\
\text { installation of meters and implemen- } \\
\text { tation of energy saving measures. }\end{array}$ \\
\hline $\begin{array}{l}\text { A single state agency/organization } \\
\text { responsible for the project (either } \\
\text { assigned to an existing agency/ } \\
\text { organization or the creation of a new } \\
\text { agency/organization) }\end{array}$ & $\begin{array}{l}\text { Assigns responsibility formally within } \\
\text { the government, which potentially } \\
\text { increases accountability and lowers } \\
\text { risk. } \\
\text { Centralizes function thereby providing } \\
\text { consistency and reducing duplication. } \\
\text { The widest powers according to the } \\
\text { status ensured by the Cabinet of } \\
\text { Ministers' Decree \#414. }\end{array}$ & $\begin{array}{l}\text { Agency personnel may lack capability } \\
\text { to manage/administer financial } \\
\text { processes. }\end{array}$ \\
\hline $\begin{array}{l}\text { A single municipal agency/organization } \\
\text { - organization responsible for the } \\
\text { project (either assigned to an existing } \\
\text { municipal agency/organization or the } \\
\text { creation of a new agency/organization) }\end{array}$ & $\begin{array}{l}\text { Assigns responsibility formally within } \\
\text { the municipal agency, which potentially } \\
\text { increases accountability and lowers } \\
\text { risk. } \\
\text { Centralizes function thereby providing } \\
\text { consistency and reducing duplication. } \\
\text { The widest powers according to the } \\
\text { status ensured by the Cabinet of } \\
\text { Ministers' Decree } \# 414 \text {. }\end{array}$ & $\begin{array}{l}\text { Agency personnel may lack capability } \\
\text { to manage/administer financial } \\
\text { processes. } \\
\text { Tendency for municipal property focus. }\end{array}$ \\
\hline
\end{tabular}


Table 4.1 (contd)

\begin{tabular}{|c|c|c|}
\hline Assignee/Description & Pro's & Con's \\
\hline $\begin{array}{l}\text { Two agencies/organizations - } \\
\text { organization responsible for the project } \\
\text { and a municipal agency/ organization } \\
\text { with powers delegated by the } \\
\text { organization responsible for the project } \\
\text { (either assigned to existing agencies/ } \\
\text { organizations or the creation of a new } \\
\text { agencies/organizations) }\end{array}$ & $\begin{array}{l}\text { Assigns responsibility formally within } \\
\text { the government, which potentially } \\
\text { increases accountability and lowers } \\
\text { risk. } \\
\text { Provides recognition of ownership } \\
\text { responsibilities--state and municipal. } \\
\text { The widest powers according to the } \\
\text { status ensured by the Cabinet of } \\
\text { Ministers' Decree \#414. }\end{array}$ & $\begin{array}{l}\text { Agency personnel may lack capability } \\
\text { to manage/administer financial } \\
\text { processes. } \\
\text { Possible duplication of capability, } \\
\text { added complexity, and more difficult } \\
\text { coordination. }\end{array}$ \\
\hline Individual agencies/organizations & $\begin{array}{l}\text { Assigns responsibility to owning } \\
\text { organizations. }\end{array}$ & $\begin{array}{l}\text { Increases the number of ultimate } \\
\text { recipients, which provides for } \\
\text { duplication of capability, complexity } \\
\text { and coordination. } \\
\text { Agencies/organizations personnel may } \\
\text { lack capability to manage/administer } \\
\text { financial processes. } \\
\text { Possible diversion of funding to other } \\
\text { purposes and possible arrears of } \\
\text { payments to installer/supplier. }\end{array}$ \\
\hline
\end{tabular}

\subsection{Loan Disbursement (Steps 1 and 8)}

Loan disbursement is the assignment of responsibility for the loan to ensure accountability and that payments to service providers are made in a timely manner in accordance with accepted and agreed upon procedures. Origination of loan disbursement requests and tracking the disbursement process is a major responsibility of the PIO subordinated to the Organization Responsible for the Project.

Responsibilities:

- Prepare bidding documents in conjunction with the procurement and installation branches of the PIO.

- Conduct international competitive bidding in conjunction with the procurement branch of the PIO.

- Apply for currency withdrawal (disbursement requests) to pay installers/suppliers.

- Provide accounting for loan. 
The structure of the disbursement process specified within the framework of Decree \#414 and World Bank requirements is presented in Figure 4.2.

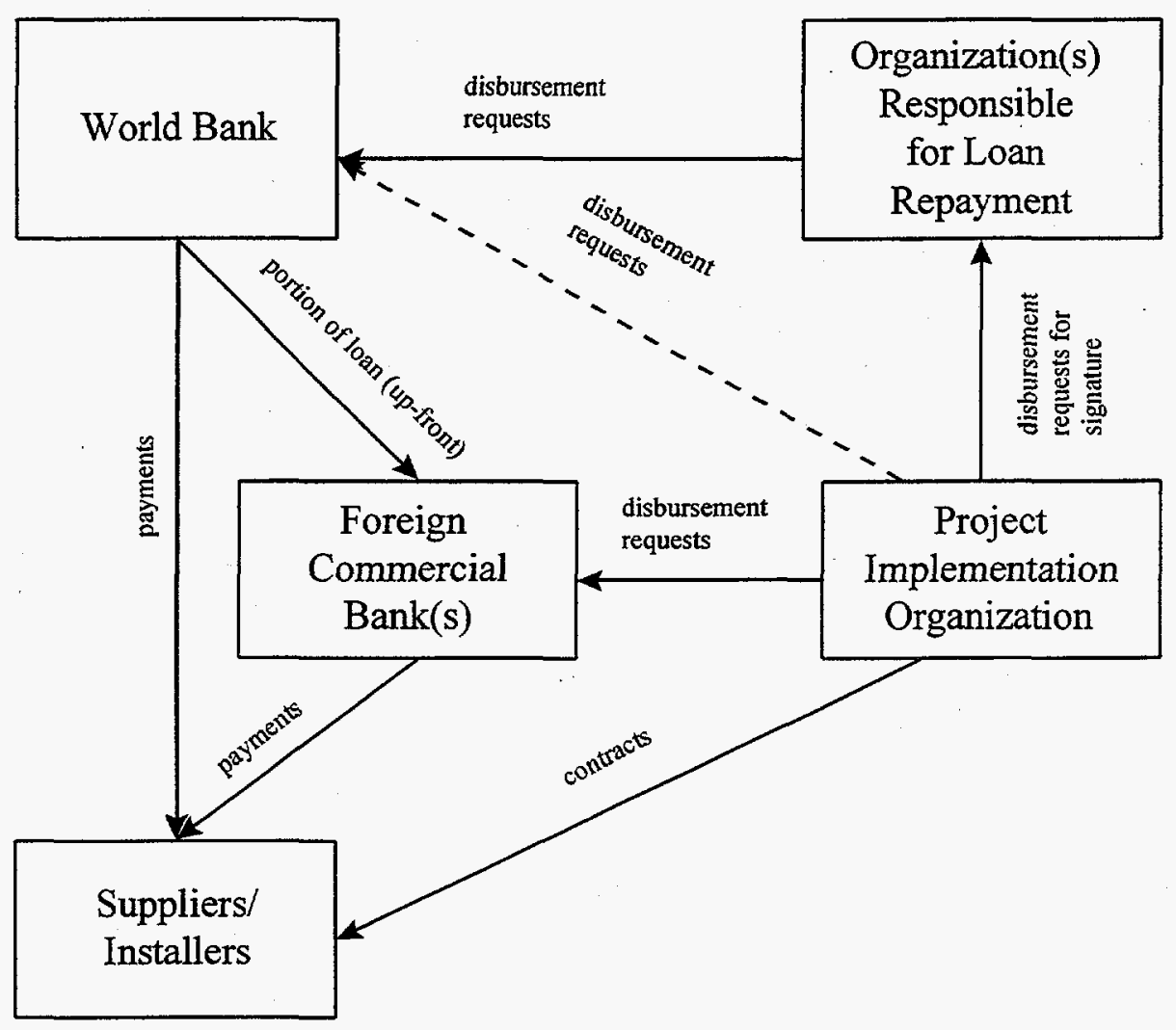

Figure 4.2. Loan Disbursement Process

This scheme shows the disbursement process, irrespective of the organization responsible for the project. Generally, the World Bank makes direct payments to suppliers/installers, although a certain portion of the loan may be allocated to a special account to cover current payments on smaller contracts. The special account is created in a foreign commercial bank satisfying World Bank requirements and approved by the Ministry of Finance, with the special account opened for the Ministry of Finance and sub-borrower (under a license of the Ministry of Finance).

The PIO makes contracts and originates disbursement requests to pay suppliers and installers. The disbursement requests may be subject to approval by the Organization Responsible for the Project and/or other implementing organizations and the Ministry of Finance. The disbursement requests are delivered to the World Bank to issue payment. The PIO may also have direct access to the special account provided that the Ministry of Finance submits to the World Bank documents confirming that certain persons are authorized to sign applications for withdrawal and certified samples of the authorized persons' signatures. 
The World Bank supervises the disbursement process to ensure that procurement and disbursement actions are carried out in accordance with agreed upon procedures. As part of this process, the PIO shall furnish to the World Bank plans, specifications, reports, contract documents, and installation and procurement schedules relative to the project.

Disbursements from the loan account will be made to the suppliers and installers in the currencies in which they are billed. Disbursements are made only upon requests originated by the PIO.

\subsection{Loan Service (Payment Process) (Steps 9 and 10)}

The World Bank loan most likely will be provided to Ukraine through the Ministry of Finance. The portion of the loan targeting municipally owned buildings will likely be on-lent to the Kyiv Municipality.

This section presents the budget allocation process and the repayment options.

\subsubsection{Budget Allocation Process}

The budget allocation process is described as it currently exists, as well as a modification that is planned for the near future.

\section{Current Budget Process}

At present, state budgetary organizations are financed from the state budget through a transfer of funding to accounts in banks authorized by the government to process budget expenditures. Budget resources are allocated from the Ministry of Finance to the ministry to the subordinated budgetary organizations and finally to the suppliers of goods and services. Proceeding from availability of funds in its account, the budgetary organization spends the amounts it considers necessary. Expenditure of budgetary resources is checked by the Ministry of Finance only after expenditures are made.

Municipal budgetary organizations are financed according to a similar vertical scheme - from the Municipal Department of Finance to district financial departments to organizations subordinate to district state administrations and finally to suppliers of goods and services. District financial departments are not involved when the organization is subordinated directly to Kyiv Municipality. Frequently, district financial departments, instead of subordinated organizations, make direct payments to suppliers of goods and services. During the last 2 years, the Municipal Department of Finance set budgets for some budgetary organizations without including the allocation for heat supplies, and instead made direct payments to heat suppliers. 


\section{Revised Budget Process for State Organizations}

The existing budget process does not allow the Ministry of Finance to efficiently supervise the flow of funds of budgetary organizations. This may result in decreased discipline with respect to settling accounts and improper usage of budgetary resources.

With the purpose of providing clear and efficient supervision of the use of budgetary resources and complying with the corresponding condition of a stand-by credit program of the International Monetary Fund, Decree of the President "On the State Treasury" was adopted in April 1995, and on January 14, 1997, the Cabinet of Ministers and the National Bank of Ukraine jointly adopted the Decree \#13 "On Introduction of the Treasury System for the State Budget Fulfillment."

Under the latter Decree, the State Treasury shifts to the system of paying invoices issued to budgetary organizations (instead of the existing system of budget allocation). Payments will be transferred directly to the accounts of suppliers who sell their goods or services to budgetary organizations. This system is displayed in Figure 4.3.

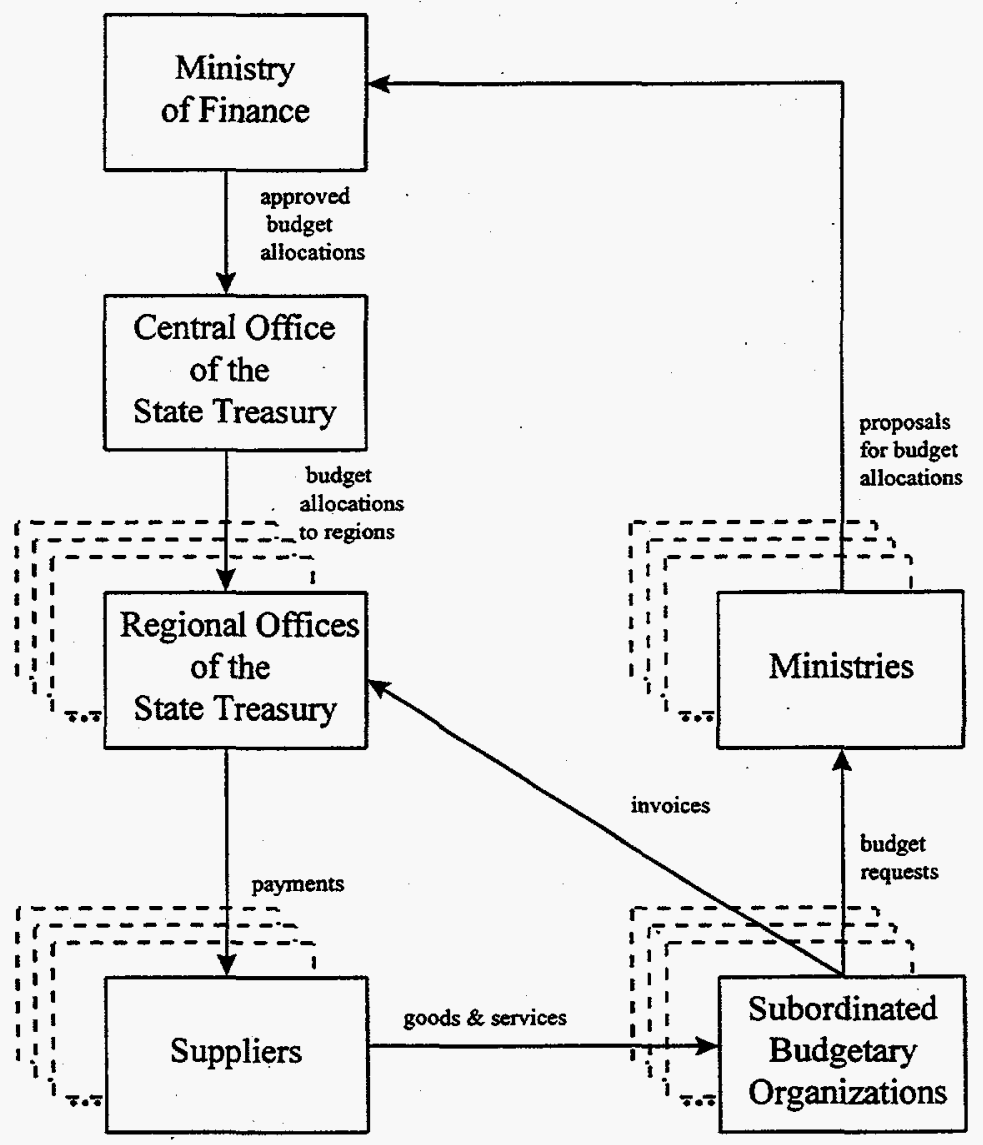

Figure 4.3. Operation of New Treasury System 
Under this scheme, the Ministries and Departments will determine budget allocations for themselves and their subordinate organizations. The Ministries and Departments will, under supervision and by consent of the Treasury, make contracts with suppliers and pass the invoices back to the Treasury for payment.

Introduction of the treasury system for budget fulfillment will proceed over time. This process is scheduled to begin on July 1, 1997, at which time the State Treasury will be paying the bills for all institutions under the Ministry of Health.

\subsubsection{Repayment Options}

Four repayment options are listed in Table 4.2. The first two are termed the "centralized repayment" option with these two organizations (the Ministry of Finance and the Kyiv Municipality) focusing the repayment process. The third is best described by a "decentralized repayment" scenario with the four sub-organizations mentioned in the introduction of Chapter 4 having direct responsibility for servicing the loan. A combination of the centralized and decentralized options is also presented. The fourth option shown in the table is not discussed in this section.

It is possible that the state organizations and the Municipality may insist upon separate PIOs.

This is not recommended as it will likely result in duplication of effort, increased cost, and complication. It is recommended that a single PIO represent the interests of the state and Municipality through the operation of the Oversight Committee.

Table 4.2. Collection and Repayment Options for Servicing the Loan

\begin{tabular}{|c|c|c|}
\hline Assignee/Description & Pro's & Con's \\
\hline \multicolumn{3}{|l|}{ Centralized } \\
\hline $\begin{array}{l}\text { Ministry of Finance collects/deducts } \\
\text { payment from budget allocation. }\end{array}$ & $\begin{array}{l}\text { The method is simple, fixed, } \\
\text { centralized, and ensures payment. }\end{array}$ & $\begin{array}{l}\text { May apply only to state } \\
\text { organizations. }\end{array}$ \\
\hline $\begin{array}{l}\text { Kyiv Municipality collects/deducts } \\
\text { payment from budget allocation. }\end{array}$ & $\begin{array}{l}\text { The method is simple, fixed, } \\
\text { centralized, and ensures payment. }\end{array}$ & $\begin{array}{l}\text { May apply only to municipal } \\
\text { organizations. }\end{array}$ \\
\hline \multicolumn{3}{|l|}{ Decentralized } \\
\hline $\begin{array}{l}\text { Rely on recipient organizations to } \\
\text { provide payment to designated loan } \\
\text { manager. }\end{array}$ & $\begin{array}{l}\text { Places responsibility for payment } \\
\text { on recipients. }\end{array}$ & $\begin{array}{l}\text { Nonpayment may be an issue. } \\
\text { Transfer of funds between state and } \\
\text { municipal organizations may be an } \\
\text { issue. }\end{array}$ \\
\hline \multicolumn{3}{|l|}{ Other ${ }^{(2)}$} \\
\hline $\begin{array}{l}\text { Kyiv Energo and/or Kyiv Municipal } \\
\text { District Heating Company. Include } \\
\text { surcharge in heating bill. }\end{array}$ & $\begin{array}{l}\text { Utilizes established billing and } \\
\text { payment process. }\end{array}$ & Nonpayment may be an issue. \\
\hline
\end{tabular}




\section{Centralized Repayment}

The centralized repayment option is shown in Figure 4.4 where the Ministry of Finance and the Kyiv Municipality provide for the collection of the funds and loan payment.

In this option, the World Bank lends to the Ministry of Finance of Ukraine with a sovereign guarantee provided by the Cabinet of Ministers. The Ministry of Finance concludes an agreement with the Kyiv Municipality to on-lend part of the loan in the amount necessary to pay for efficiency measures in targeted municipal buildings.

Collections by both the Ministry of Finance and the Kyiv Municipality are handled by reductions in the annual budget allocations to the subordinate organizations. The budget reductions correspond to the value of calculated energy savings from baseline consumption levels.

The municipal payments are transferred to a special account with the Kyiv Office of the State Treasury attached to the Ministry of Finance. These payments contain the principal, interest, and 1\% markup allowed to the Ministry of Finance for loan handling and processing. The Ministry of Finance provides for the loan service according to the schedule set by the loan agreement.

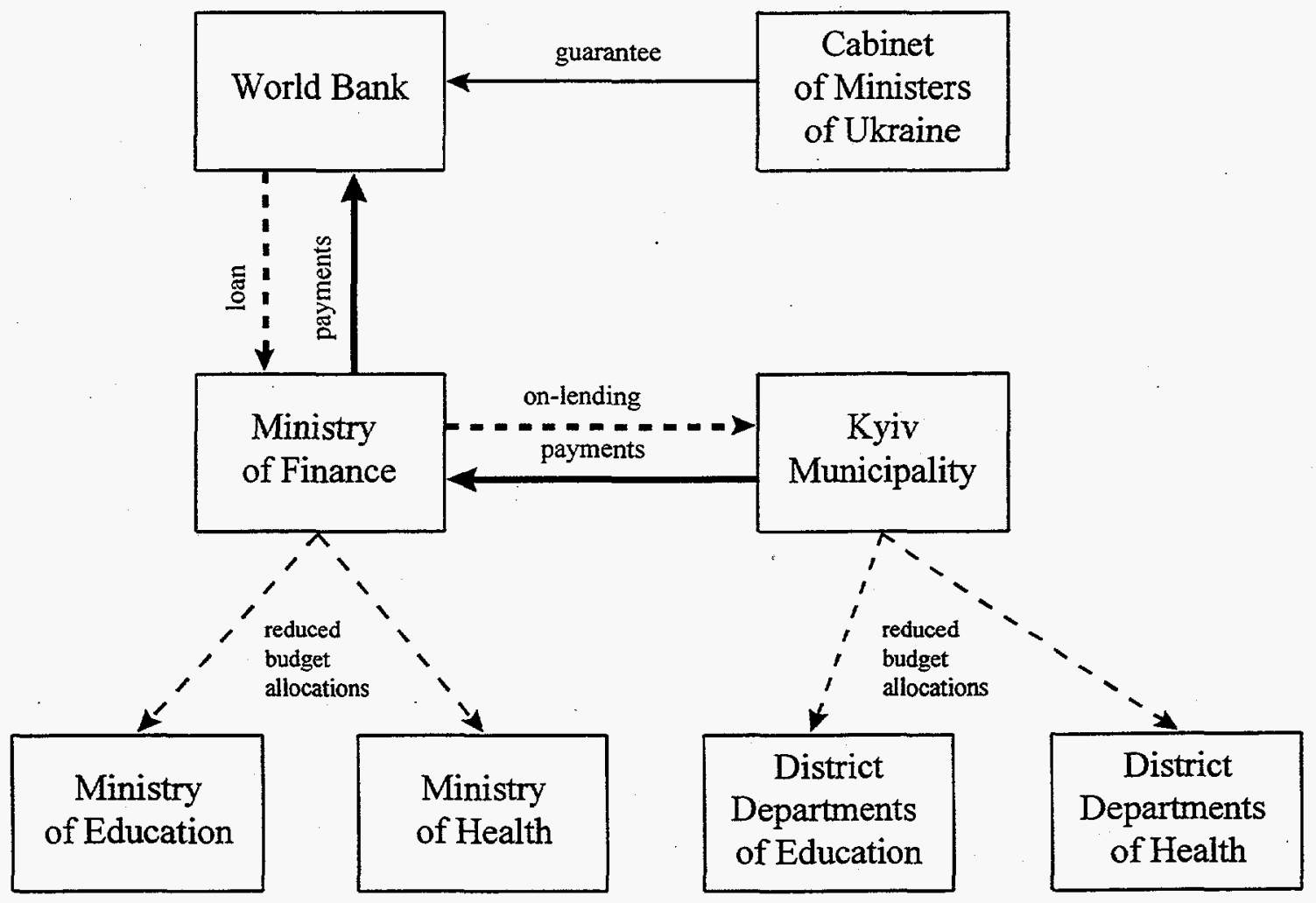

Figure 4.4. Centralized Repayment Option 
In the case of arrears of payments on the sub-loan to the Kyiv Municipality, the Ministry of Finance acts in accordance with its own Order \#88 of April 30, 1996; the procedure for transferring to the state budget amounts taken from legal persons (borrowers) to acquit debts on foreign loans guaranteed by the Government of Ukraine. This procedure was set to comply with the Cabinet of Ministers of Ukraine's Decree \#1002 of December 14, 1996, "On procedure of compensating for the state budget losses that resulted from occurrence of events guaranteed against in agreements on foreign loans received by Ukrainian legal persons under guarantees of the Government of Ukraine" (Cabinet of Ministers of Ukraine 1996b).

\section{Decentralized Repayment}

The decentralized repayment option is shown in Figure 4.5 where the Ministry of Finance and the Kyiv Municipality delegate the responsibility for the collection of the funds and loan payment to subordinate organizations.

In this option (as in the centralized repayment option), the Ministry of Finance on-lends part of the loan to the Kyiv Municipality in the amount necessary to pay for efficiency measures in targeted municipal buildings.

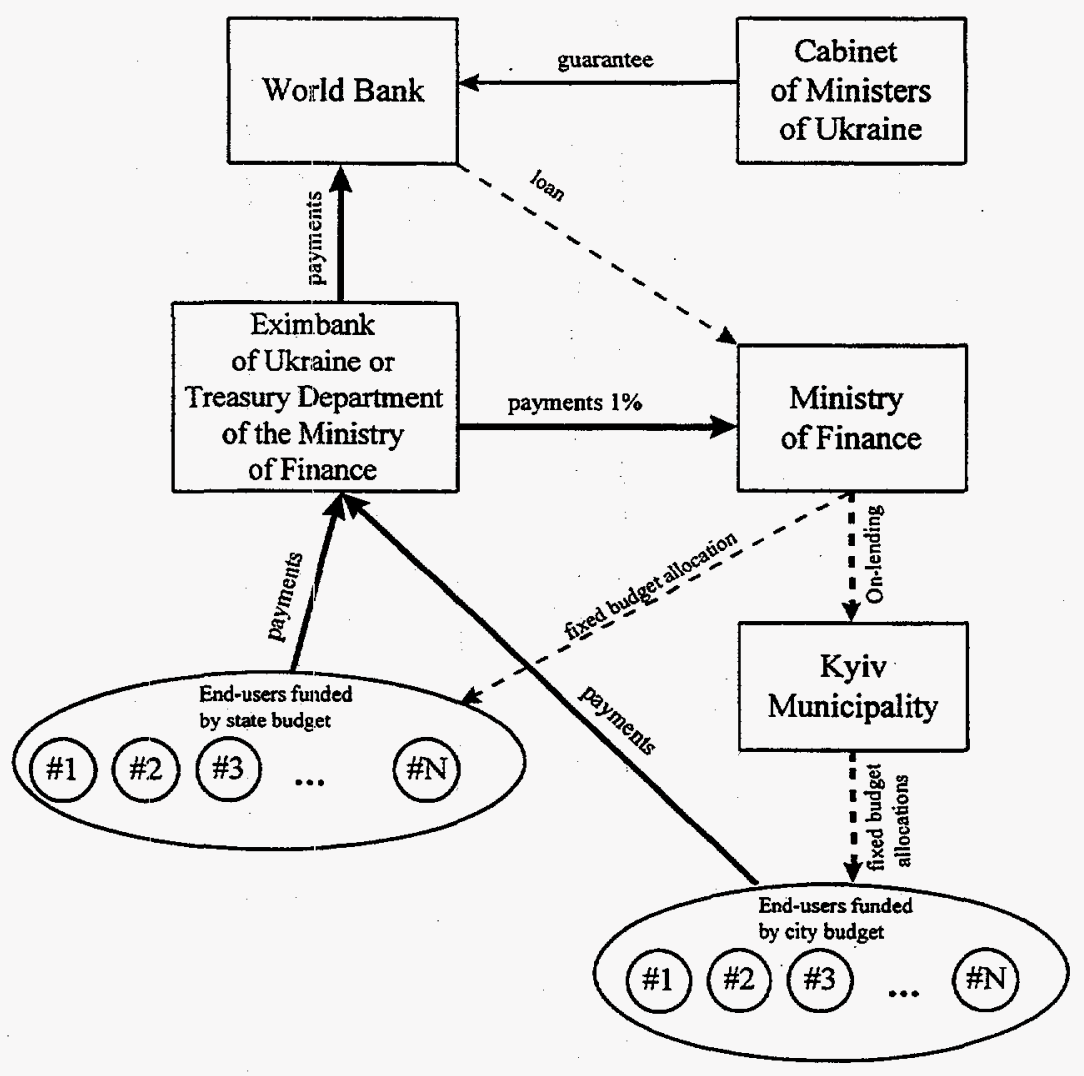

Figure 4.5. Decentralized Repayment 
For state organizations, the Ministry of Finance sets the annual budget allocations for the Ministry of Education and the Ministry of Health for their heat energy bills during the entire life cycle of the project based on an agreed upon heat consumption baseline. Fixed budget allocations are calculated to cover annual heat consumption of these ministries' subordinate budgetary organizations at the beginning of project implementation. In turn, the ministries set fixed budget allocations for subordinate organizations (universities, institutes, healthcare institutions, etc.) according to the contract values of heat consumption or an agreed upon baseline for the beginning of the project period. Subordinate budgetary organizations participating in the project then provide the amounts necessary for loan service according the calculated energy efficiency improvement for the buildings under their specific control.

Similarly, the Kyiv Municipality sets fixed annual budget allocations for the district departments of education and of health for their heat energy bills during the entire life cycle of the project. Fixed budget allocations are calculated to cover annual heat consumption of these departments' subordinate budgetary organizations at the beginning of project implementation. District departments, in turn, set fixed budget expenditures of subordinate organizations (schools, kindergartens, healthcare institutions, etc.) according to existing contracts with heat suppliers.

Organizations subordinated to the Kyiv Municipality provide for the loan service and repayment of their part of the loan in a manner similar to organizations subordinated to the Ministry of Education and the Ministry of Health. The only difference is that payments of municipal organizations include $1 \%$ markup on sub-loans paid to the Ministry of Finance to cover its administration expenses connected with on-lending.

The loan service payments of municipal organizations are transferred to a special account with the Kyiv Office of the State Treasury attached to the Ministry of Finance or to an account with the State Export-Import Bank (Eximbank) of Ukraine. According to the Cabinet of Ministers' Decree "On sovereign guarantees for foreign loans given to Ukraine under international agreements" (Cabinet of Ministers of Ukraine 1993) Eximbank of Ukraine is authorized to handle the repayment process for such loans.

In the case of arrears resulting from the failure to comply with the payment schedule on the part of State Organizations (recipients) subordinated to the Ministries of Education or Health or sub-borrower, the Ministry of Finance in accordance with the above-mentioned Order \#88 may transfer corresponding amounts from the state budget to a special account with Eximbank to service the loan. In the case of arrears by municipal organizations subordinated by the Municipality, the State Treasury reduces the municipal budget by the required amount, and the funds are placed directly to the Eximbank account from which loan payments are made. 
An apparent advantage of the decentralized option is that it potentially provides greater incentive for the end-users to engage in energy efficiency, because the balance of cost savings could be used for other purposes by the respective organization. In the case of a complete diversion of the cost savings to the state and municipal budgets under the centralized option, end-user interest in an energy efficiency program may be lower, thereby reducing the maximum effectiveness of such a program.

An important note is that according to Decree \#13, the State Treasury is switching to a system of paying the invoices issued to budgetary organizations, instead of the existing system of financing their accounts (a description of this system is located in Section 4.3.1). This system makes it impossible for organizations to spend budgetary resources in an improper way, that is, to use them in ways other than required by the initially approved expense budget. The treasury system imposes stricter control over correct usage of budget resources and may have negative consequences by reducing incentives to save energy.

\section{Mixed Centralized/Decentralized Repayment}

A possible solution to the problem of incentives could be to include conditional expenses into the budget of an organization (end-user of efficiency measures), which could be paid if cost savings resulted in a positive balance after heat supplies and loan payments were covered.

The transition to the treasury system for paying the bills of budgetary organizations may exclude an opportunity to implement decentralized payment procedures for organizations subordinated to the Ministries of Education and Health. However, the decentralized option could be applied to municipal organizations.

Under the mixed centralized/decentralized scenario, the Ministry of Finance is the focus of the repayment process as described in the centralized option in Figure 4.6, and the municipal organizations repay their portion of the loan as described in the third option (decentralized payment) listed in Table 4.2. 


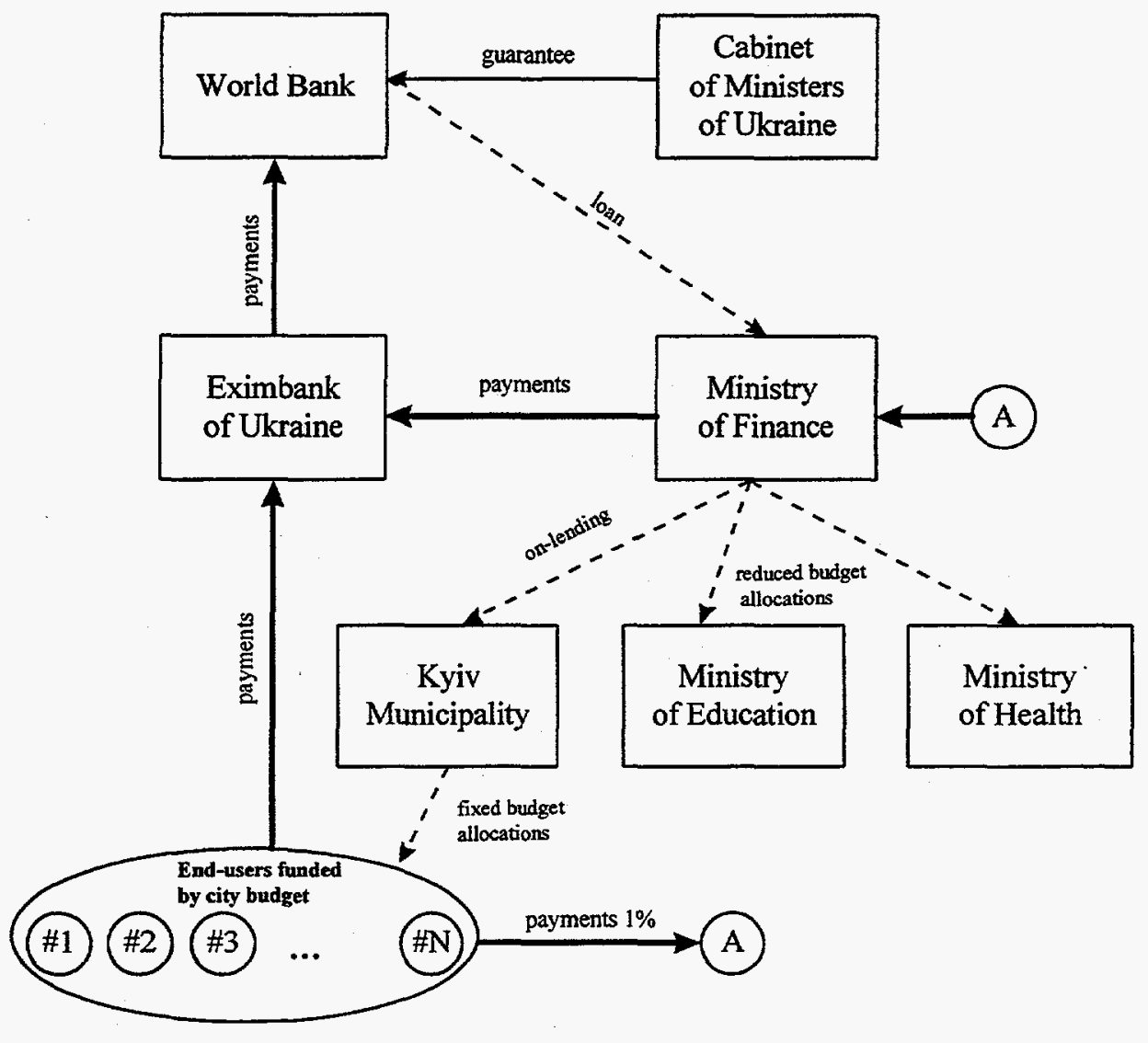

Figure 4.6. Mixed (state centralized/city decentralized) Repayment Option (Note: the A's connect to each other.) 


\subsection{Implementation Structure}

This chapter presents options for the implementation/installation structure. Though the implementation/installation structure and the financing/lending structure are related, and hence need be considered together, they are discussed separately to reduce complexity. The financing/lending structure was presented in Chapter 4. The preference for any given option in one activity may affect the preference for an option within another activity and/or the assignment of responsibility to a particular organization.

Steps in the lending and implementation processes are listed below. The steps shown in italics are the major activities in the implementation/installation process. These steps apply to the installation of the equipment and measures and follow-up to ensure that measures provide the expected levels of energy efficiency improvement. The italicized steps are discussed in this chapter.

Step 1. designate loan agent(s)

Step 2. specify target buildings

Step 3. procure/designate the installation agent(s) and supplier(s) (performed jointly with procurement activity)

Step 4. installation audit and measure specification

Step 5. installation

Step 6. installation acceptance

Step 7. operations and maintenance $(O \& M)$ training

Step 8. pay installer

Step 9. collect payments

Step 10. service loan

Step 11. verification and incentives.

To the extent possible, the discussions in Chapters 4 and 5 present options. with the pro's and con's of each. In so doing, the intent is to provide a framework for discussions among the participating organizations and to avoid making a specific recommendation whenever possible. Exceptions do occur, and single recommendations are provided when options are limited by a regulatory or legislative act, or 
alternatives are clearly not workable. Last, the examination is not comprehensive and is intended to generate additional discussion of the options identified and to identify additional options.

As stated in Chapter 4, it is anticipated that the potential loan will be directed to the retrofit of buildings belonging to:

- Two state organizations under the purview of the Ministry of Finance

- Ministry of Health (healthcare buildings)

- Ministry of Education (higher education buildings)

- Two municipal organizations under the purview of the Municipal Department of Finance

- Municipal Department of Education (primary and secondary education buildings)

- Municipal Department of Culture

Thus, there are two to four owning organizations, depending upon how they are defined, for determining the lending and repayment structure.

This chapter is organized into two subsections. The first, Installation Responsibilities, provides the major activities and steps in the installation process and options for assigning responsibility for the installation of equipment and measures. The second, Ensuring Persistence, provides a number of actions that may be considered to ensure equipment and measures provide the expected levels of efficiency improvement and options for the assignment of these responsibilities.

\subsection{Installation Responsibilities}

Implementation consists of the installation of measures and equipment as well as training and establishment of mechanisms to maximize efficiency gains. Criteria for the installation process include:

- minimize cost

- minimize disruption to occupants

- minimize interruption of service

- maximize quality of installation (i.e., minimize rework and recall and maximize efficiency improvement).

The responsibility for meeting these criteria is shared among all persons and entities involved in the installation process, but ultimately day-to-day responsibility resides with the PIO. 
Major steps in the installation process (indicated on pg 5.1 as steps 2 through 6 ) are as follows:

2. Specify target buildings. Identify and develop a schedule of buildings to be retrofitted. This step is to be performed in conjunction with the "owning" agency, building occupants (head administrative official and building manager), and installers.

3. Procure/designate the installation agent(s) and supplier(s). This step is performed in two activities. The first step, in conjunction with the procurement staff of the PIO, is to select the installation agents and/or suppliers of equipment and materials. The second activity is to designate the particular installers and suppliers to a specific building following step 4, below.

4. Installation audit and measure specification. This step provides an audit of each site/building to identify the types and quantities of applicable equipment and measures.

5. Installation. This step provides for the physical installation of the equipment and measures.

6. Installation acceptance. This step involves an inspection of each building/installation to ensure that equipment and materials were installed to meet acceptable quality standards.

Table 5.1 provides organizational options to perform these five steps and is based on installation and acceptance categories and pro's and con's for each.

\subsubsection{Example Implementation/Installation Structure Options}

This subsection provides three example implementation options. The three example options separate the installation activity into a management/oversight role, the equipment/material supply role, and a physical installation role. A number of responsibilities are assigned to each role as follows:

\section{Base Responsibilities}

- Procure equipment, materials, and installation contractors according to applicable procurement guidelines.

- Schedule retrofits in individual buildings.

- Design, review, and approve the audit.

- Review and approve design documents for applicable equipment/materials before submission to design office.

- Assist in developing and evaluating procurements.

- Inspect and accept installations (quality assurance).

- Provide performance verification of installed equipment/materials.

- Compile necessary reports on the installation process.

- Design training program for building managers and occupants (accomplished in conjunction with installation organization[s]). 
Table 5.1. Organizational Options for Installation of Energy Efficiency Equipment and Measure

\begin{tabular}{|c|c|c|}
\hline Assignee/Description & Pro's & Con's \\
\hline \multicolumn{3}{|c|}{ Physical installation may be carried out by } \\
\hline - Central government entity & Centralizes organizational responsibility & $\begin{array}{l}\text { Does not encourage private sector } \\
\text { enterprise }\end{array}$ \\
\hline $\begin{array}{l}\text { Owning government } \\
\text { organizations }\end{array}$ & $\begin{array}{l}\text { Responsibility is placed directly with } \\
\text { landlords, which may result in higher } \\
\text { quality installations }\end{array}$ & $\begin{array}{l}\text { Does not encourage private sector } \\
\text { enterprise } \\
\text { Government organization may not be } \\
\text { as responsive as private sector } \\
\text { enterprise }\end{array}$ \\
\hline $\begin{array}{l}\text { Limited number }(1-3) \text { of } \\
\text { private sector organizations } \\
\text { that provide turnkey } \\
\text { installation service }\end{array}$ & $\begin{array}{l}\text { Supports development of private sector } \\
\text { enterprise } \\
\text { Focuses capability and responsibility } \\
\text { May result in higher quality installations }\end{array}$ & \\
\hline $\begin{array}{l}\text { Individual private sector } \\
\text { installers and vendors of } \\
\text { equipment and measures }\end{array}$ & $\begin{array}{l}\text { Supports development of private sector } \\
\text { enterprise } \\
\text { Focuses capability and responsibility } \\
\text { May result in higher quality installations }\end{array}$ & $\begin{array}{l}\text { Individual agencies/organizations may } \\
\text { be responsible for coordinating } \\
\text { installers } \\
\text { May lead to duplication of effort } \\
\text { May complicate acceptance }\end{array}$ \\
\hline \multicolumn{3}{|c|}{ Acceptance responsibility may be assigned to } \\
\hline $\begin{array}{l}\text { Loan management } \\
\text { agency/organization }\end{array}$ & Centralizes responsibility & $\begin{array}{l}\text { Would involve a diversion of } \\
\text { responsibility for financial and } \\
\text { engineering issues }\end{array}$ \\
\hline - PIO & $\begin{array}{l}\text { Centralizes responsibility } \\
\text { Focuses capability and responsibility } \\
\text { May result in higher quality installations }\end{array}$ & \\
\hline $\begin{array}{l}\text { Owning government } \\
\text { organization }\end{array}$ & $\begin{array}{l}\text { Responsibility resides with owning } \\
\text { organization, which may lead to higher } \\
\text { quality installations }\end{array}$ & $\begin{array}{l}\text { May not have uniform expertise } \\
\text { Provides for duplication of capability }\end{array}$ \\
\hline - Independent organization & $\begin{array}{l}\text { Centralizes responsibility } \\
\text { May be considered unbiased due to } \\
\text { independence } \\
\text { Focused capability }\end{array}$ & \\
\hline
\end{tabular}




\section{Installation Responsibilities}

- Provide for the import and delivery of equipment and materials.

- Provide for the storage of equipment and materials.

- Perform the audit of each building to specify types and amounts of necessary equipment and materials.

- Prepare the design documents for applicable equipment/materials.

- Perform the physical installation of applicable equipment/materials.

- Perform operational check-out of applicable equipment/materials.

- Administer training program for building managers and occupants (accomplished in conjunction with PIO[s]).

Three example schemes for organizing these functions are provided in Figures 5.1, 5.2, and 5.3. For these examples, three types of equipment/materials are identified (meters, controls, and weatherization), although it is recognized that additional or fewer types may be required.

\section{Consolidated PIO and Installation Organization}

In this scheme (shown in Figure 5.1), the PIO and Installation Organization are the same. Under this scheme, it is recommended that the PIO be organized to separate the two responsibilities (management/oversight and installation) as it is felt that the quality of the process will be improved.

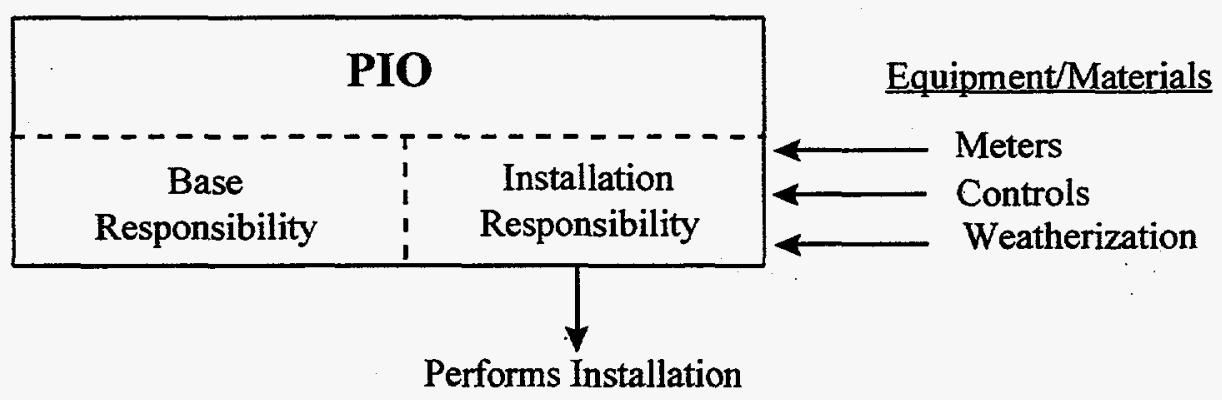

Figure 5.1. Consolidated Project Implementation Organization and Installation Organization

\section{Separated PIO and Installation Organization}

In the scheme (shown in Figure 5.2), the base responsibilities are separated between the Project Implementation Organization and a general contractor such as an Energy Services Contractor (ESCO) to perform the installation activities. 


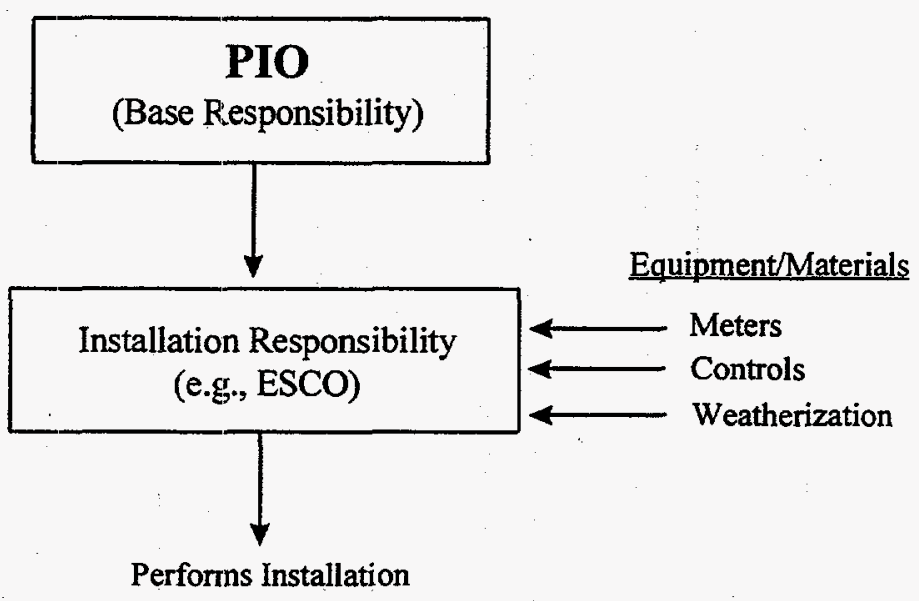

Figure 5.2. Separated Project Implementation Organization and Installation Organization

In this scheme (shown in Figure 5.3), the base responsibilities are separated between the PIO and the suppliers or installers for individual technologies. There is no general contractor such as an ESCO.

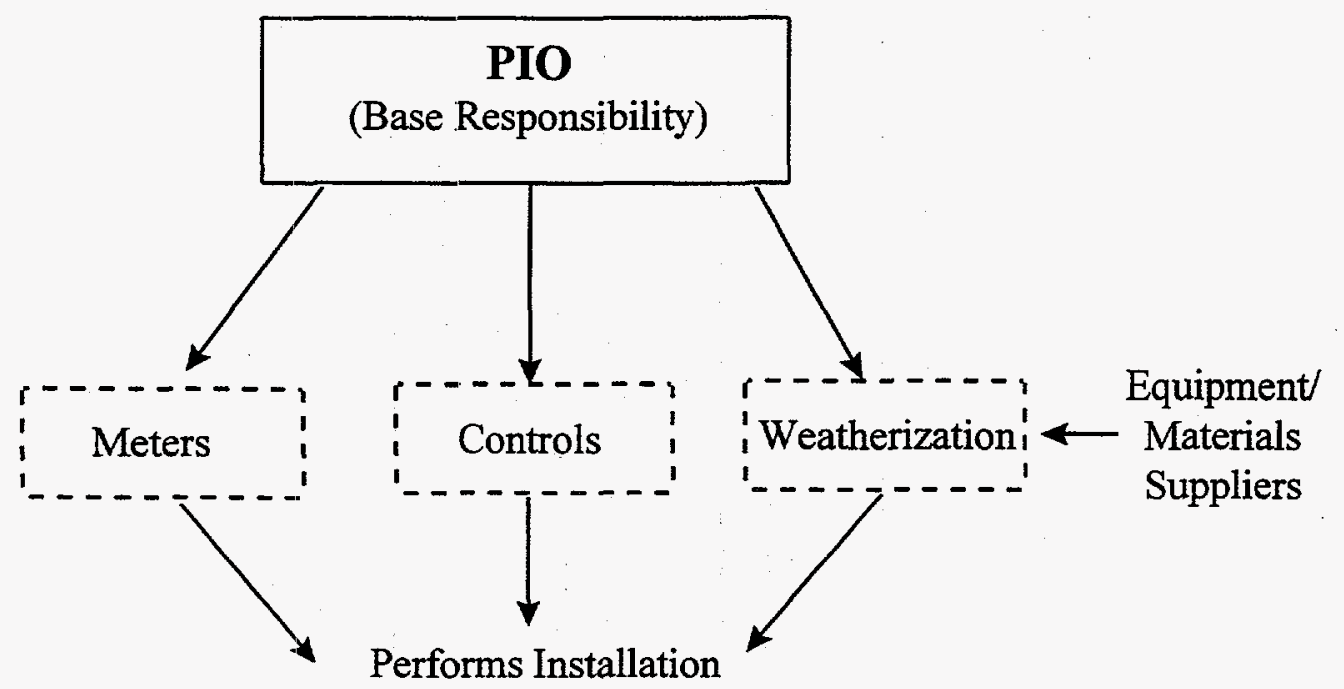

Figure 5.3. Separated Project Implementation Organization and Installation Organization (Installation provided by suppliers or individual installers for each type of equipment/material) 


\subsubsection{Installation Recommendations}

It is recommended that

- A phased approach be employed to install the equipment and measures in a limited number of buildings to identify and adjust for necessary modifications to the recommended ECO packages, and to the installation process that includes scheduling, audit, physical installation, and acceptance processes.

- At least two installers and suppliers be used for each type of equipment and material to ensure that specific needs are met and to reduce risk.

It is also recognized that municipal and state organizations may desire to retain direct responsibility for the installation process. Options may include:

1. Participating organizations relinquish this control as a condition for participating in the program.

2. Installation process is structured to maximize use of resources of the participating organizations, while retaining a single $\mathrm{PIO}$.

3. Resources of the participating organizations are utilized, and two or more PIOs are created.

The second option is recommended because it will create the greatest knowledge and ownership of the equipment/measures, utilize relevant participant resources, centralize the management and reporting functions, maximize quality of the installations, and result in lowest overall cost for the installation and administration functions.

\subsection{Ensuring Persistence (Steps 7 and 11)}

This activity is to ensure that energy reductions resulting from efficiency improvements are realized for a sustained period. Ensuring persistence is composed of two actions - O\&M education and training, and verification coupled with incentives.

O\&M education and training is relatively straightforward. This effort should be focused on building managers and occupants. There may be benefits that will transfer to other sectors such as residential energy efficiency improvements as a result of information and training provided to the occupants of primary and secondary education facilities (students and parents). Support for O\&M efforts may also be elicited from interested parties such as parents of students in primary and secondary education facilities, aficionados of cultural events, or other supports. A recent inquiry by the World Bank indicates that, in some cases, third parties may be a primary source of support to ensure sustainability - while enlisting support from others may be a stand alone activity, it is included within the O\&M education and training category at this time. 
Verification is a necessary component of O\&M and incentive actions and it is assumed that this activity is performed by the PIO. One rule of thumb developed from an extensive retrofit program (the LOANStar Program in the state of Texas) is that an investment equal to $5 \%$ of the retrofit cost in verification will provide an additional efficiency gains equivalent to a simple payback of less than 2 years. Although it is not known if this level of return is applicable to these buildings and circumstances, it is recommended that a verification plan be developed and implemented. Verification has an obvious role in the management (both installation and financial) and may also benefit the persistence of the equipment and measures. A verification protocol developed by the DOE may be adapted to this program (DOE 1996). A more complete description of a proposed verification process in presented in Appendix E.

Incentives may be diverse in nature, type(s), and their administration. Incentives may consist of:

- metering and reporting

- annual awards

- monetary (retain a portion of subsidy for other uses)

- other publicity (such as quality of service).

Administrative options for providing O\&M education/training and incentives are presented in Table 5.2. 
Table 5.2. Administrative Options for Providing O\&M Education/Training and Incentives

\begin{tabular}{|c|c|c|}
\hline Assignee/Description & Pro's & Con's \\
\hline \multicolumn{3}{|c|}{ O\&M Training Options } \\
\hline $\begin{array}{l}\text { Loan management } \\
\text { agency/organization }\end{array}$ & Centralizes responsibility & $\begin{array}{l}\text { Would involve a diversion of } \\
\text { responsibility for financial and } \\
\text { engineering issues }\end{array}$ \\
\hline - PIO & $\begin{array}{l}\text { Centralizes responsibility } \\
\text { Ensures consistency }\end{array}$ & \\
\hline $\begin{array}{l}\text { Owning government } \\
\text { organization }\end{array}$ & $\begin{array}{l}\text { Responsibility resides with owning } \\
\text { organization }\end{array}$ & $\begin{array}{l}\text { May not have uniform expertise } \\
\text { Provides for duplication of capability }\end{array}$ \\
\hline Independent organization & $\begin{array}{l}\text { Centralizes responsibility } \\
\text { Targeted capability } \\
\text { Encourages private sector activity }\end{array}$ & \\
\hline Installation contractors & $\begin{array}{l}\text { Centralizes responsibility } \\
\text { Targeted capability } \\
\text { Encourages private sector activity }\end{array}$ & $\begin{array}{l}\text { May provide for duplication of capability, } \\
\text { lack of coordination, and may lack } \\
\text { comprehensiveness }\end{array}$ \\
\hline \multicolumn{3}{|c|}{ Incentive Administration Options } \\
\hline $\begin{array}{l}\text { Loan management agency/ } \\
\text { organization }\end{array}$ & Centralizes responsibility & $\begin{array}{l}\text { Diverse responsibilities - diversion from } \\
\text { financial issues }\end{array}$ \\
\hline $\mathrm{PIO}$ & $\begin{array}{l}\text { Centralizes responsibility } \\
\text { Ensures consistency }\end{array}$ & \\
\hline $\begin{array}{l}\text { Owning government } \\
\text { organization }\end{array}$ & $\begin{array}{l}\text { Responsibility resides with owning } \\
\text { organization }\end{array}$ & $\begin{array}{l}\text { Incentives are diverse - lead to duplication } \\
\text { of capability } \\
\text { Not independent }\end{array}$ \\
\hline - Independent organization & Independent/unbiased & $\begin{array}{l}\text { Incentives are diverse - may not have } \\
\text { range of capability }\end{array}$ \\
\hline Installation contractors & & $\begin{array}{l}\text { Diversion of purpose } \\
\text { Insufficient capability } \\
\text { Not independent }\end{array}$ \\
\hline
\end{tabular}




\subsection{Risk Assessment}

This section provides a discussion of the risks that may exist and that may affect the successful implementation of the proposed energy efficiency improvements. Each of the potential risks is presented in a structure that describes the nature of the risk, its potential impact on the project, and the mitigation strategy(ies). A number of the potential risks have been addressed in the technical assessment and the resolution is provided in the mitigation strategy section of the applicable risk. A number of the potential risks will be resolved as the lending and implementation structures are defined. 


\section{Risk Title: Sovereign Guarantee}

\section{Characterization}

The provision of a sovereign guarantee is essential for obtaining a loan from the World Bank to implement efficiency measures in institutional buildings.

\section{Potential Impact}

The existence of a sovereign guarantee is a go/no-go condition for the efficiency implementation program.

\section{Mitigation Strategy}

The State Committee for Energy Conservation and the Agency of Reconstruction and Development have applied to the Ministry of Finance to obtain a sovereign guarantee.

The State Committee and the Agency of Reconstruction and Development are actively working with the cognizant organizations to seek support and obtain approval for a sovereign guarantee. 


\section{Risk Title: Nonpayment}

\section{Characterization}

The recipient agencies/organizations of the installed efficiency measures may not provide the agreed upon payment(s) to service the potential loan.

\section{Potential Impact}

Failure of the recipient agencies/organizations to make their payments could:

- cause the government to default on the loan, and/or

- increase the payments of other recipients to repay the loan.

\section{Mitigation Strategy}

- Develop a contract stipulating the payment due. This contract would specify the payment stream, the efficiency improvements, verification of the efficiency improvements, and other terms deemed important, and/or

- Structure the payment process so that the payment is deducted from the recipient agency/organization budget rather than rely upon the agency to make timely payment; i.e., utilize a centralized repayment option. 


\section{Risk Title: Implementation Capability}

\section{Characterization}

There are three aspects to this risk:

- The commitment by the agencies/organizations to dedicate the necessary human, physical, and financial resources to the program.

- The capability of the implementing organization(s) to organize and manage a large-scale efficiency program.

- Personnel turnover within the agencies/organizations as staff acquire the knowledge and capability to organize and manage a program.

\section{Potential Impact}

- The performance of the efficiency measures may be negatively impacted, and the level of energy efficiency improvement may be less than expected.

- The program may be faced with higher costs, scheduling delays, lower quality installations, continual training of staff, and other factors associated with low productivity.

\section{Mitigation Strategy}

This risk was addressed in part in the technical assessment where the sensitivity (switching value) analysis showed that the efficiency improvement could decline from the average of $26 \%$ to $9-21 \%$, depending on the building type, before the investment would cease to be cost-effective.

Factors that can reduce or eliminate risks associated with lack of implementation capabilities include:

- Screen participating agencies/organizations based upon commitment

- Provide training for implementation

- Engage consultants to assist with implementation

- Increase remuneration to staff to encourage retention

- Focus implementation within a single or limited number of implementing organizations. 


\section{Risk Title: Equipment/Measure Cost}

\section{Characterization}

The cost for equipment and measures may be very different than the assumed values. The cost may differ for the equipment and measures themselves, the quantity and cost of labor to install them, and/or applicable import fees and taxes.

\section{Potential Impact}

- the measures cost more than the estimated values, the cost-effectiveness of the efficiency may be lower. Conversely, if the measures cost less than estimated, a higher level of efficiency may be justified.

- Higher costs will also increase the value of the loan package resulting in higher payments for the recipients.

\section{Mitigation Strategy}

This risk was addressed in part in the technical assessment where the sensitivity (switching value) analysis showed that costs could increase from 1.2 to 2.8 times, depending on the building type, and the investment would still be considered cost-effective. Even at that, costs (equipment/measures, labor, and administration) will be developed to be as accurate as possible.

The contingency assigned is in part to cover any increase in the investment level that may result from a slight increase in the installed cost of measures or a significantly lower cost for measures that provide for inclusion of additional measures. 


\section{Risk Title: Fuel Cost}

\section{Characterization}

The cost for heat may be very different than the assumed value(s). This may be caused by tariff adjustments resulting from policy and/or cost recovery. The cost of input fuel is one component of cost recovery, as are O\&M costs, and fixed costs associated with other aspects of the proposed loan.

\section{Potential Impact}

If the fuel (heat) costs less than assumed, a lower level of efficiency may be justified.

Conversely, if the fuel (heat) costs more than assumed, a higher level of efficiency may be justified.

\section{Mitigation Strategy}

This risk was addressed in the technical assessment where a heat tariff of $\$ 22 / \mathrm{Gcal}$ was used. It is felt that this value approximates the variable component of a two-tiered tariff that is scheduled to be implemented in the near future. Although the objective of the sensitivity (switching value) analysis was not to examine the sensitivity of the investment to the heat tariff, this sensitivity can be easily obtained from the calculations. It can be shown that the heat tariff could decrease to $\$ 8-18 / \mathrm{Gcal}$, depending upon the building type, before the investment would cease to be cost-effective. 


\section{Risk Title: Environmental Factors}

\section{Characterization}

There are four aspects that pertain to environmental risks:

- applicable Ukrainian regulatory policies and/or requirements

- applicable World Bank regulatory policies and/or requirements

- impacts associated with the equipment/measures dealing with removal, worker exposure, and disposal of hazardous materials/substances

- decreases in emissions of combustion byproducts attributable to the efficiency improvements.

\section{Potential Impact}

Failure to account for or comply with environmental factors could result in:

- unacceptable health risks to workers and/or the occupants

- increased costs to the project through unanticipated costs and/or fines

- delay in the installation of measures

- cancellation of the project.

\section{Mitigation Strategy}

This risk has been addressed in part in the technical assessment in that Ukrainian and World Bank regulations and/or requirements were reviewed. It was determined that:

- Emissions from combustible sources would decrease.

- Asbestos was not commonly used as an insulating and/or building material. The presence of asbestos can best be determined in the building audit that would occur before the installation and specification of the energy efficiency measures. If asbestos was determined to exist, removal and disposal could be addressed at that time. 
- Panels manufactured in the 1970 s contained some industrial waste. It is unlikely that the energy efficiency retrofits would lead to disturbance of these panels. The need to disturb the panels can best be determined in the building audit that would occur before the installation and specification of the energy efficiency measures. If the panels were to be disturbed, handling and disposal could be addressed at that time.

- Indoor air quality could be negatively impacted by weatherization measures. It is felt that indoor air quality issues can best be identified and dealt with at the time the energy audit that would occur before the installation and specification of the energy efficiency measures.

- Soil contamination is not considered to be an issue because it is unlikely that soil within the boundary of the building or near the building perimeter would be disturbed. The need to disturb soil can best be determined in the building audit that would occur before the installation and specification of the energy efficiency measures.

- Ozone-depleting substances can best be dealt with in the tenders for equipment and materials. 


\section{Risk Title: Nonenvironmental Regulatory Factors}

\section{Characterization.}

Nonenvironmental regulatory factors may bear upon the actions that agencies/organizations are allowed to take, the treatment of agency/organization budgets, the structure of the repayment process, and other factors that affect implementation.

\section{Potential Impact}

These factors may increase the cost or affect the schedule or ability to implement an efficiency program.

\section{Mitigation Strategy}

A review of all applicable factors will be conducted during the initial stage of establishing the PIO.

The implementation process will be designed to account for these factors.

Changes in policy and/or regulation will be sought, where appropriate, to mitigate nonenvironmental regulatory factors that may impede implementation. 


\section{Risk Title: Equipment/Measure Performance}

\section{Characterization}

This risk pertains to the ability of the equipment and measures to provide the estimated efficiency improvements. Sources of error may be:

- inaccurate engineering estimates

- occupant behavior

- O\&M personnel capability

- accountability and incentives.

\section{Potential Impact}

Inaccurate estimates of the efficiency improvement may lead to a lower (higher) return than anticipated if the equipment/measure underperforms (overperforms). The risks of underperformance have implications for the recipients of the measures and repayment of the loan.

- If the loan payment is based on the estimated improvement and the measures underperform, the agency/organization pays for a level of service not realized.

- If the loan payment is based on actual efficiency improvements as agreed upon by the verification protocol and the measures under perform, then the value of the energy efficiency improvement may be insufficient to service the loan.

In the case of overperformance (i.e., the measures provide a greater-than-predicted efficiency improvement), the recipients obtain a greater level of service than is agreed upon, or the value of the energy efficiency improvement may exceed the level required to service the loan.

\section{Mitigation Strategy}

This risk was addressed in part in the technical assessment where the sensitivity (switching value) analysis showed that the efficiency improvement could decline from the average of $26 \%$ to $9-21 \%$, depending on the building type, before the investment would cease to be cost-effective. 
Factors that have been accounted for in the analysis and will continue as PIO responsibilities include:

- Incorporate the experience of other assessments, demonstrations, and efficiency programs. This has been done and will continue.

- Rely on passive measures as much as possible. This has been factored into the analysis.

Factors to mitigate lower than expected measure performance include:

- Minimize access to equipment/measures, especially active equipment/measures.

- Install a "package" of measures where possible to provide diversity (from active and passive aspects), rather than rely on the performance of an individual measure.

- Provide education to occupants.

- Provide training and information to O\&M personnel.

- Require ongoing verification and performance measures.

- Provide incentives to the extent possible.

- Incorporate flexibility in the loan payment structure (within reason) to account for inaccurate estimates. 


\section{Risk Title: Under Heating}

\section{Characterization}

The estimation of energy use reduction may be overpredicted if actual heat supplied by the primary heating fuel is less than the norm $\left(18^{\circ} \mathrm{C}\right.$ indoor temperature). In the case of underheating by the primary fuel source (district heat in this case), the estimated energy use reduction should account for secondary fuel(s) used for heating.

\section{Potential Impact}

Underheating may lead to overpredicting the energy use reduction, and hence a higher payback than is actually realized. Thus, the recipient agency/organization may "overpay" for the service received -- see Equipment/Measure Performance risk.

\section{Mitigation Strategy}

This issue poses the greatest difficulty in addressing because insufficient metered data exist to assess the degree and scale of underheating. The technical assessment estimated the energy use reductions based upon the norm, knowing that underheating occurs during peak periods and assuming that overheating occurs at nonpeak periods, and assuming that the two approximately balance out from an energy standpoint.

Regarding secondary heat sources, it was assumed that such sources will not be utilized as intensively because the primary heat source (district heat) will provide $18^{\circ} \mathrm{C}$ service over a greater range of temperatures. Additionally, the estimated energy use reductions will account for the assumed amount and value of the secondary fuels used.

These assumptions will be verified to the extent possible from experiences reported in other studies and from observations and measurements taken over the 1996/97 heating season. 


\section{Risk Title: Non-Energy Efficiency Rehabilitation Expense}

\section{Characterization}

The occupant requests improvements that are not directly related to improving energy efficiency. The improvements requested have a stronger relationship to occupant health and safety and/or facility/building usability. Such improvements would normally be covered under a maintenance program.

\section{Potential Impact}

The inclusion of the costs of non-energy efficiency improvements into the energy efficiency loan may transform a cost-effective improvement into a non-cost-effective improvement.

Performing non-energy efficiency improvements may divert the time, attention, and resources of the installation teams from the intended purpose of their effort; i.e., installation of energy efficiency measures.

\section{Mitigation Strategy}

The audit and installation protocol developed by the PIO will address the possibility of requests for non-energy efficiericy improvements. Such improvements will likely not be within the scope of the installation contractor contracts. The PIO will have to approve the audit and measures to be installed and can forward requests for non-energy efficiency measures to agency management. 


\section{Risk Title: Foreign Exchange}

\section{Characterization}

The purchasing power of the loan amount may decrease or increase over time due to changes in exchange rates.

\section{Potential Impact}

In the event that the purchasing power of the loan amount decreases over time, energy efficiency improvements can be accomplished in fewer buildings and the repayment must be borne by the energy efficiency derived from a smaller number of buildings.

\section{Mitigation Strategy}

This risk can be addressed in the context of the Equipment/Measure Cost risk. The Equipment/ Measure Cost risk was addressed in part in the technical assessment where the sensitivity (switching value) analysis showed that the costs could increase from 1.2 to 2.8 times, depending on the building type, before the investment would cease to be cost-effective. Even at that, the costs (equipment/ measures, labor, and administration) will be developed as accurately as possible.

In addition, the World Bank will provide options in the terms of its loan to Ukraine. Two common options are:

- Provide the loan in the currencies and amounts expected to be required for the purchase of goods and services. Thus, the currencies are matched to the purchases and any fluctuations in purchasing power are automatically covered. This strategy may be considered applicable if the costs of procurements by origin are known with reasonable certainty.

- Provide the loan in what is termed a market basket of currencies to obtain stability in purchasing power through offsetting fluctuations. This strategy may be considered applicable if the cost of procurements by origin are less certain. 


\subsection{Implementation and Financing Schedules}

This chapter consists of two sections. The first section provides a proposed schedule for the initiation and conduct of the activities. The second section provides several alternatives for structuring the financing and repayment of the potential loan(s).

\subsection{Implementation Schedule}

The implementation schedule presented in this section is intended to provide the major activities and their associated schedules. The assumed formal start date for the installation activities is the first quarter of calendar year 1998 with the activities continuing through the first quarter of 2002 . For this installation schedule to be met, a number of preparatory activities pertaining to project development and approval must occur in the latter half of calendar year 1997. The schedule of the preparatory and installation activities for the period beginning with the third quarter of 1997 through the third quarter of 2002 are presented in Table 7.1 .

The installation activities presented below reflect a phased approach. In Phase I, the installation process is limited to 40 buildings in order to 1) verify the cost and performance of the recommended measures, and 2) identify and refine the installation and management procedures. Although it is likely that a phased approach will result in reduced uncertainty and higher quality, it is recognized that full-scale installation activities are delayed for a heating season. An option is to forego the two-phased process and proceed with full-scale installation activities as outlined in Phase II.

Other assumptions provided in the implementation schedule are that the potential World Bank loan would be disbursed annually, semi-annual meetings would be convened by the Project Oversight Organization to review the status of the installation and loan service activities, and annual awards would be presented to recognize the achievements of participants.

\subsubsection{Preparatory Activities}

During the latter half of 1997 , a number of activities will need to be accomplished prior to the start of installation activities; these activities are described as follows:

- June/July. Complete and obtain general agreement on the Technical Assessment by the providers of capital and loan recipients. Major factors include the baseline, energy efficiency gains, installed equipment/measure costs, types of equipment/measures, and investment levels.

Lead Responsibility: Consultants and State Committee. 


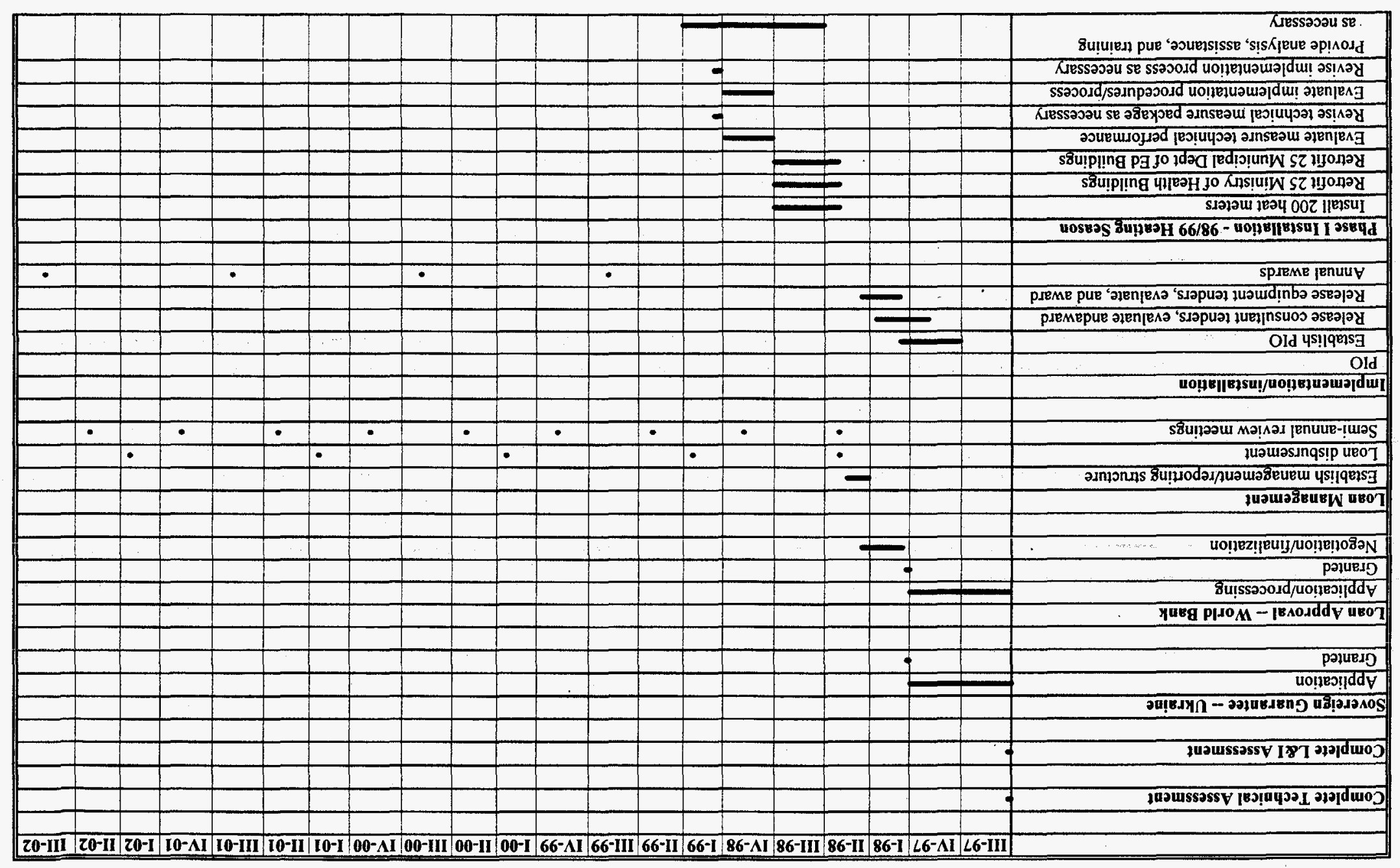


Table 7.1. Example Implementation Schedule (contd)

\begin{tabular}{|c|c|c|c|c|c|c|c|c|c|c|c|c|c|c|c|c|c|c|c|c|}
\hline & \begin{tabular}{|l|l|l|l|l|l|} 
III-97 & IV-97 \\
\end{tabular} & $1-98$ & II-98 & III-98 & IV-98 & 1-99 & II-99 & III-99 & IV-99 & $\mathbf{I}-\mathbf{0 0}$ & II-00 & III-00 & IV-00 & I-01 & II-01 & III-01 & IV-01 & $\mathbf{I}-\mathbf{0 2}$ & II-02 & III-02 \\
\hline \multicolumn{21}{|l|}{ Phase II Installation 99/00 Heating Season } \\
\hline \multicolumn{21}{|l|}{ Install 725 heat meters } \\
\hline \multicolumn{21}{|l|}{ Retrofit 100 Ministry of Health Buildings } \\
\hline \multicolumn{21}{|l|}{ Retrofit 300 Municipal Dept of Ed Buildings } \\
\hline \multicolumn{21}{|l|}{$\begin{array}{l}\text { Evaluate measure performance, revise } \\
\text { as necessary }\end{array}$} \\
\hline \multicolumn{21}{|l|}{$\begin{array}{l}\text { Evaluate installation process, revise } \\
\text { as necessary }\end{array}$} \\
\hline \multicolumn{21}{|l|}{$\begin{array}{l}\text { Provide analysis, assistance, and training } \\
\text { as necessary }\end{array}$} \\
\hline & & & & & & & & & & & & & & & & & & & & \\
\hline \multicolumn{21}{|l|}{$00 / 01$ Heating Season } \\
\hline \multicolumn{21}{|l|}{ Install 753 heat meters } \\
\hline \multicolumn{21}{|l|}{ Retrofit 100 Ministry of Health Buildings } \\
\hline \multirow{2}{*}{\multicolumn{21}{|c|}{$\begin{array}{l}\text { Retrofit } 300 \text { Municipal Dept of Ed Buildings } \\
\text { Retrofit } 150 \text { higher education buildings }\end{array}$}} \\
\hline & & & & & & & & & & & & & & & & & & & & \\
\hline \multicolumn{21}{|l|}{ Retrofit 20 cultural buildings } \\
\hline \multicolumn{21}{|l|}{$\begin{array}{l}\text { Provide analysis, assistance, and training } \\
\text { as necessary }\end{array}$} \\
\hline & & & & & & & & & & & & & & & & & & & & \\
\hline \multicolumn{21}{|l|}{ 01/02 Heating Season } \\
\hline \multicolumn{21}{|l|}{ Retrofit 114 Ministry of Health Buildings } \\
\hline \multirow{2}{*}{\multicolumn{21}{|c|}{$\begin{array}{l}\text { Retrofit } 364 \text { Municipal Dept of Ed Buildings } \\
\text { Retrofit } 157 \text { higher education buildings }\end{array}$}} \\
\hline & & & & & & & & & & & & & & & & & & & & \\
\hline \multicolumn{21}{|l|}{ Retrofit 23 cultural buildings } \\
\hline $\begin{array}{l}\text { Provide analysis, assistance, and training } \\
\text { as necessary }\end{array}$ & & & & & & & & & & & & & & & & & & & & \\
\hline
\end{tabular}


- June/July. Complete the Lending and Implementation Assessment to provide options for the loan and implementation/installation structures and processes.

Lead Responsibility: Consultants and State Committee.

- July - September. Further define and obtain general agreement on the lending and implementation/ installation structures and processes.

Lead Responsibility: State Committee.

- June/July - December. Petition for sovereign guarantee.

Lead Responsibility: State Committee

- August - December. Establish functioning implementation and associated management organizations.

Lead Responsibility: State Committee.

- September - December. Obtain agreement on the terms of the potential loan with recipient organizations and obtain issuance of the potential loan in the first quarter of 1998.

Lead Responsibility: State Committee and World Bank.

\subsubsection{Phase I}

Phase I activities are planned to be initiated in the fourth quarter of 1997 and conducted through approximately the first quarter of 1999 . Installation activities will be focused on the $98 / 99$ heating season. Lead responsibilities were not assigned at this time.

Major activities within Phase I are:

- Finalize establishment of the Project Management Organization(s) and reporting procedures.

- Finalize establishment of the PIO(s) and initial implementation/installation procedures.

- Complete the release and evaluation of the tenders and award contracts for the equipment, materials, and installation. 
- Install a limited number of heat meters (approximately 100, for example) to provide a baseline for the subsequent installation of efficiency measures. It may be desirable to focus on Ministry of Health and Municipal Department of Education buildings, which are the types that are anticipated to be retrofitted in the 99/2000 heating season.

- Install efficiency measures in a limited number of buildings (approximately 20, for example) owned by Ministry of Health and (approximately 20 , for example) owned by the Municipal Department of Education. Objectives of a limited installation are:

1. To prove the performance (energy efficiency) and cost-effectiveness of the bundles of measures identified in the Technical Assessment. It is suggested that the sample of buildings be segmented to 1) examine the performance of marginal measures identified in the Technical Assessment, and 2) pretest the performance of measures in buildings of the type that will be the subject of retrofit in the $99 / 2000$ heating season.

2. To establish the implementation and installation mechanisms. This will consist of developing the initial processes for the implementation and installation, exercising those processes from the second quarter of 1998 through the fourth quarter of 1998, and revising the implementation/ installation process/procedures early in the first quarter of 1999. These processes/procedures are expected to cover:

\begin{tabular}{l} 
Implementation \\
\hline - PIO semi-annual meetings \\
- Reporting_installation, performance, \\
and financial \\
- Loan disbursement \\
- Awards/recognition (requires \\
input from verification activity)
\end{tabular}

\begin{tabular}{l} 
Installation \\
\hline - Schedule audits/installations \\
- Conduct, approve and accept audits \\
- Develop installation design and \\
obtain design and installation \\
pproval \\
- Perform physical installation \\
- Inspect/accept installation \\
- Provide O\&M training for "active" \\
measures \\
- Provide for measurement and \\
verification of efficiency measures
\end{tabular}

\subsubsection{Phase II}

The Phase II activities are scheduled to take place from the first quarter of 1999 through the third quarter of 2002. The focus of this discussion is the installation process, because it is anticipated that implementation activities will be carried out in accordance with revisions identified in Phase I. 
The Phase II installation process will implement revisions to the Phase I process to perform fullscale retrofit of the stock of target institutional buildings over the 99/2000,2000/2001, and 2001/2002 heating seasons. The proposed schedule of activities by heating season is:

\section{9/2000 Heating Season}

- Increase staffing of PIO (see Table C.2) to handle the increase in installation and verification activities.

- Install about one-half of the heat meters. It is suggested that these be installed in buildings to be retrofitted in this and the next heating seasons.

- Retrofit about one-third of Ministry of Health buildings.

- Retrofit about one-third of Municipal Department of Education buildings.

- Retrofit a limited number of additional (other than Ministry of Health and Municipal Department of Education) buildings that will be targeted for retrofit in the 2000/2001 heating season to prove the performance (energy efficiency) and cost-effectiveness of measures identified in the Technical Assessment.

It is suggested that the sample of buildings be segmented 1) to examine the performance of marginal measures identified in the Technical Assessment, and 2) to pretest the performance of measures in buildings types that will be the subjects of retrofit in the 2000/2001 heating season.

- Perform verification of the performance of retrofits and provide feedback and assistance to building managers/operators.

\section{0/2001 Heating Season}

- Install about one-half of the heat meters. It is suggested that these be installed in buildings to be retrofitted in this and the next heating seasons.

- Retrofit about one-third of Ministry of Health buildings.

- Retrofit about one-third of Municipal Department of Education buildings.

- Retrofit about one-half of the other buildings.

- Perform verification of the performance of retrofits and provide feedback and assistance to building managers/operators. 


\section{1/2002 Heating Season}

- Retrofit about one-third of Ministry of Health buildings.

- Retrofit about one-third of Municipal Department of Education buildings.

- Retrofit about one-half of the other buildings.

- Perform verification of the performance of retrofits and provide feedback and assistance to building managers/operators.

\subsection{Cost and Financing of Alternatives}

Three alternative financing scenarios were constructed to provide alternative views to financing the potential investment. It is recognized that these are not the only possible options for structuring the financing, but it is felt that these alternatives represent the bounds that may exist and provide guidance for Ukraine in structuring a package.

The scenarios were constructed to show alternatives for an anticipated investment of about $\$ 38$ million over a 5-year period of which $\$ 31.1$ million is for the actual installation of equipment/ measures, $\$ 3.5$ million is for project implementation (administration) (the estimate and position requirements for one construct of the PIO are contained in Appendix C), and \$3.5 million is for contingency. Each scenario provides the source(s) of capital, the payment structure, and cash flow to Ukraine. Also for each scenario, the NPV of the cash flow is provided.

The three scenarios are presented in Tables 7.2 through 7.7 as follows:

- Table 7.2 provides Scenario 1a where the World Bank provides $80 \%$ ( $\$ 30.4$ million) and Ukraine provides the remaining 20\%. In this scenario, the loan from the World Bank is for the period 1998 through 2014. A negative cash flow exists in the first 3 years, with a high of $-\$ 2.4$ million in 1999 and a maximum cumulative value of $-\$ 4.1$ million in the year 2000 . The NPV of this scenario at a $10 \%$ discount rate is $\$ 17$ million, and the cash outflow (funds that flow out of Ukraine to service the loan) is $\$ 53.5$ million.

- Table 7.3 provides Scenario $1 \mathrm{~b}$, where the sources of capital are the same as in scenario $1 \mathrm{a}$, but the loan is paid off sooner (in 2007) by dedicating $100 \%$ of the reduction in the energy bill to the loan payment. The negative cash flow conditions remain the same as in 1a, but the cash flow is zero in the 4-year period 2003 through 2006 reflecting the dedication of $100 \%$ of the efficiency savings to the loan payment. The annual cash flow is greater in later years than in Scenario la. The NPV is somewhat less ( $\$ 16.4$ million), and the cumulative cash outflow is $17 \%$ less at $\$ 44.3$ million. 


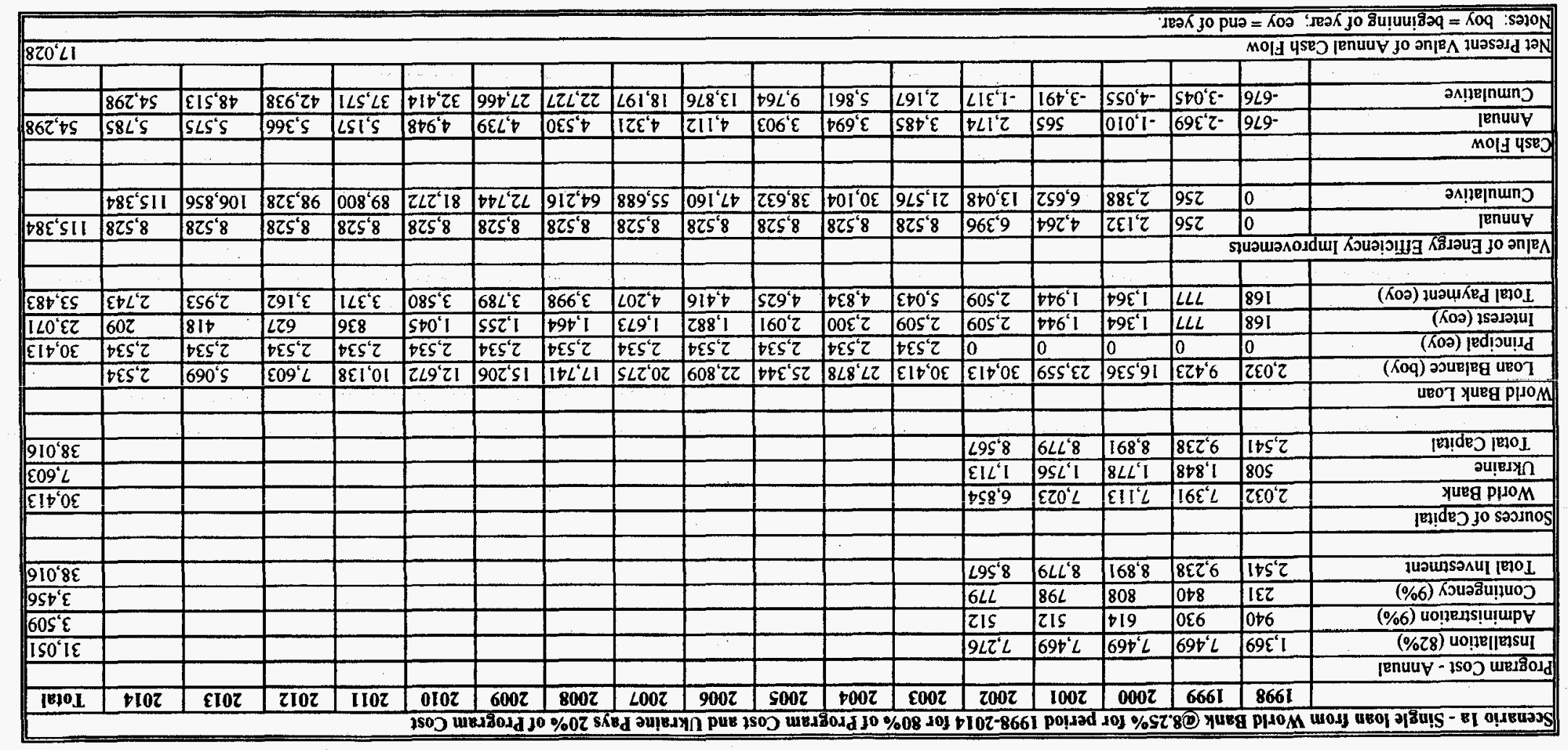

(\$ puesnoul) ) 
Table 7.3. Financing Seenario tb for the Kyiv Institutional Building Assessment (thousand \$)

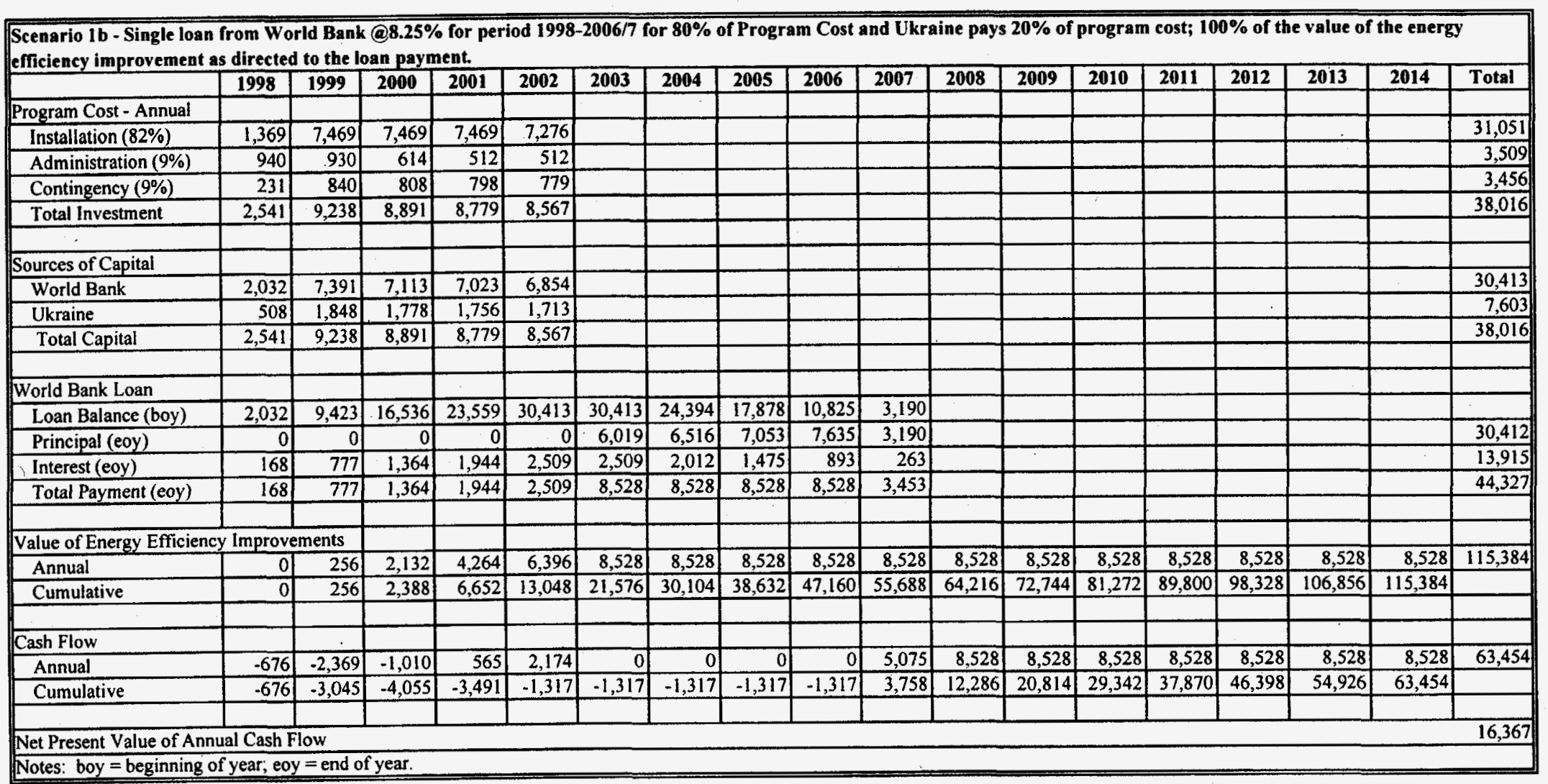


- Table 7.4 provides Scenario 2a in which there are two loans. The World Bank provides $80 \%$ of the capital, and a third party provides the remaining 20\%. The World Bank loan is for the period 1998 through 2014, and the higher cost third-party loan is paid off as quickly as possible (by the year 2002). A negative cash flow condition exists in the first 5 years, with a peak of $-\$ 1.9$ million in the year 2001 and a cumulative value of $-\$ 5.6$ million. The NPV of this scenario is about $\$ 14.6$ million, and the cash outflow is about $\$ 58.6$ million.

- Table 7.5 provides Scenario 2b. The sources of capital are the same as in 2a, but the World Bank portion of the loan is paid off sooner (2007) by dedicating $100 \%$ of the reduction in the energy bill to the loan payment. The negative cash flow conditions remain the same as in $2 a$, but the cash flow is zero in the 4-year period 2003 through 2006 , reflecting the dedication of $100 \%$ of the efficiency to the loan payment. The annual cash flow is greater in later years than in Scenario 2a. The NPV is somewhat less ( $\$ 14$ million), and the cumulative cash outflow is about $14 \%$ less at $\$ 50.6$ million.

- Table 7.6 provides Scenario 3a, where there are two loans as in $2 \mathrm{a}$, but the third party provides payment for both loans at its interest rate (25\% per annum in this example) until its loan is paid off in the year 2011; the interest rate then declines to the World Bank rate of $8.25 \%$ per annum until the year 2014. There is no out-of-pocket expense to Ukraine in this scenario as reflected in the zero cash flow. Ukraine does not realize a positive cash flow until the year 2011. The NPV of this scenario is about $\$ 3.8$ million, and the cash outflow is nearly $\$ 100$ million ( $\$ 98.2$ million).

- Table 7.7 provides Scenario 3b. The loan terms are the same as in 3a except the World Bank loan is paid off sooner (2013) by dedicating $100 \%$ of the reduction in the energy bill to the loan payment. Again, there is no out-of-pocket expense to Ukraine in this scenario as reflected in the zero cash flow. Ukraine does not realize a positive cash flow until the year 2013. The NPV of this scenario is about $\$ 3.5$ million, and the cash outflow is, again, nearly $\$ 100$ million ( $\$ 98.5$ million).

The six scenarios are summarized in Table 7.8, which shows the share of financing (capital) by source, cash flow for the first 5 years (1998 through 2002), NPV, cash outflow, and the break-even natural gas price. The cash outflow is the amount of currency estimated to flow out of Ukraine. The break-even gas price is calculated by dividing the cash outflow by the estimated import of natural gas associated with the improved energy efficiency $\left(1010\right.$ million $\mathrm{m}^{3}$, which is the estimated quantity of natural gas that would not be saved over the 15-year life of the program. Comparing this value to the actual price can be used as one indication of whether the financial structure is beneficial to Ukraine from a cash outflow standpoint. The actual natural gas price is about $\$ 84 / 1000 \mathrm{~m}^{3}$, which would indicate that Scenarios 1 and 2 are beneficial from a currency outflow standpoint, but that Scenario 3 is not. 
Table 7.4. Pinancing Scenario 2a for the Kyiv Institutional Building Assessment (thousand \$)

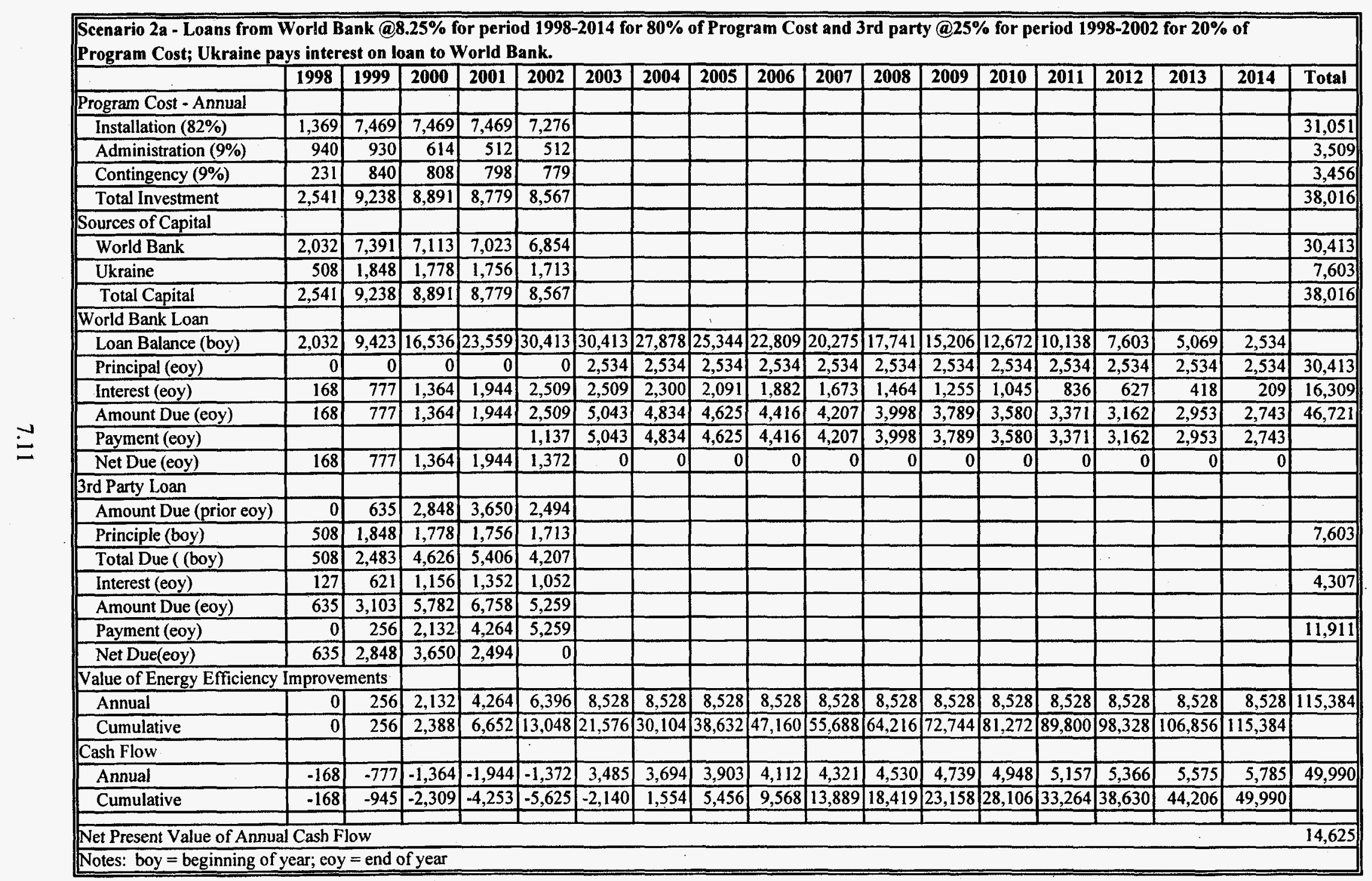


Table 7.5. Financing Scenario $2 b$ for the Kyiv Institutional Building Assessment (thousand \$)

\begin{tabular}{|c|c|c|c|c|c|c|c|c|c|c|c|c|c|c|c|c|c|c|}
\hline paysina & 1998 & 1999 & 2000 & 2001 & 2002 & 2003 & 2004 & 2005 & 2006 & 2007 & 2008 & 2009 & 2010 & 2011 & 2012 & 2013 & 2014 & Total \\
\hline \multicolumn{19}{|l|}{ Program Cost - Annual } \\
\hline Installation $(82 \%)$ & 1,369 & 7,469 & 7,469 & 7,469 & 7,276 & & & & & & & & & & & & & 31,051 \\
\hline Administration (9\%) & 940 & 930 & 614 & 512 & 512 & & & & & & & & & & & & & 3,509 \\
\hline Contingency $(9 \%)$ & 231 & 840 & 808 & 798 & 779 & & & & & & & & & & & & & 3,456 \\
\hline Total Investment & 2,541 & 9,238 & 8,891 & 8,779 & 8,567 & & & & & & & & & & & & & 38,016 \\
\hline & & & & & & & & & & & & & & & & & & \\
\hline \multicolumn{19}{|l|}{ Sources of Capital } \\
\hline World Bank & 2,032 & 7,391 & 7,113 & 7,023 & 6,854 & & & & & & & & & & & & & 30,413 \\
\hline Ukraine & 508 & 1,848 & 1,778 & 1,756 & 1,713 & & & & & & & & & & & & & 7,603 \\
\hline Total Capital & 2,541 & 9,238 & 8,891 & 8,779 & 8,567 & & & & & & & & & & & & & 38,016 \\
\hline \multirow{2}{*}{\multicolumn{19}{|c|}{ World Bank Loan }} \\
\hline & & & & & & & & & & & & & & & & & & \\
\hline Loan Balance (boy) & 2,032 & 9,423 & 16,536 & 23.559 & 30,413 & 30,413 & 24,394 & 17,878 & 10,825 & 3,190 & 0 & 0 & 0 & 0 & 0 & 0 & 0 & \\
\hline Principal (eoy) & 0 & 0 & 0 & 0 & 0 & 6,019 & 6,516 & 7,053 & 7,635 & 3,190 & & & & & & & & 30,413 \\
\hline Interest (eoy) & 168 & 777 & 1,364 & 1,944 & 2,509 & 2,509 & 2,012 & 1,475 & 893 & 263 & 0 & 0 & 0 & 0 & 0 & 0 & 0 & 8,290 \\
\hline Amount Due (eoy) & 168 & 777 & 1,364 & 1,944 & 2,509 & 8,528 & 8,528 & 8,528 & 8,528 & 3,453 & 0 & 0 & 0 & 0 & 0 & 0 & 0 & \\
\hline Payment (eoy) & & & & & 1,137 & 8,528 & 8,528 & 8,528 & 8,528 & 3,453 & 0 & 0 & 0 & 0 & 0 & 0 & 0 & 38,703 \\
\hline Net Due (eoy) & 168 & 777 & 1,364 & 1,944 & 1,372 & 24,394 & 17,878 & 10,825 & 3,190 & 0 & 0 & 0 & 0 & 0 & 0 & 0 & 0 & \\
\hline & & & & & & & & & & & & & & & & & & \\
\hline \multicolumn{19}{|l|}{ 3rd Party Loan } \\
\hline Amount Due (prior eoy) & 0 & 635 & 2,848 & 3,650 & 2,494 & & & & & & & & & & & & & \\
\hline Principle (boy) & 508 & 1,848 & 1,778 & 1,756 & 1,713 & & & & & & & & & & & & & 7,603 \\
\hline Total Due ( (boy) & 508 & 2,483 & 4,626 & 5,406 & 4,207 & & & & & & & & & & & & & \\
\hline Interest (eoy) & 127 & 621 & 1,156 & 1,352 & 1,052 & & & & & & & & & & & & & 4,307 \\
\hline Amount Due (eoy) & 635 & 3,103 & 5,782 & 6,758 & 5,259 & & & & & & & & & & & & & \\
\hline Payment (eoy) & 0 & 256 & 2,132 & 4,264 & 5,259 & & & & & & & & & & & & & 11,911 \\
\hline Net Due(eoy) & 635 & 2,848 & 3,650 & 2,494 & 0 & & & & & & & & & & & & & \\
\hline & & & & & & & & & & & & & & & & & & \\
\hline \multicolumn{19}{|c|}{ Value of Energy Efficiency Improvements } \\
\hline Annual & 0 & 256 & 2,132 & 4,264 & 6,396 & 8,528 & 8,528 & 8,528 & 8,528 & 8,528 & 8,528 & 8,528 & 8,528 & 8,528 & 8,528 & 8,528 & 8,528 & 115,384 \\
\hline Cumulative & 0 & 256 & 2,388 & 6,652 & 13,048 & 21,576 & 30,104 & 38,632 & 47,160 & 55,688 & 64,216 & 72,744 & 81,272 & 89,800 & 98,328 & $\mid 106,856$ & 115,384 & \\
\hline & & & & & & & & & & & & & & & & & & \\
\hline \multicolumn{19}{|l|}{ Cash Flow } \\
\hline Annual & -168 & -777 & $-1,364$ & $-1,944$ & $-1,372$ & 0 & 0 & 0 & 0 & 5,075 & 8,528 & 8,528 & 8,528 & 8,528 & 8,528 & 8,528 & 8,528 & 59,146 \\
\hline Cumulative & -168 & -945 & $-2,309$ & $-4,253$ & $-5,625$ & $-5,625$ & $-5,625$ & $-5,625$ & $-5,625$ & .550 & 7,978 & 16,506 & 25,034 & 33,562 & 42,090 & 50,618 & \begin{tabular}{|l|}
59,146 \\
\end{tabular} & \\
\hline & & & & & & & & & & & & & & & & & & \\
\hline Present Value of Ann & Cash Flo & & & & & & & & & & & & & & & & & 13,964 \\
\hline
\end{tabular}


Table 7.6. Financing Scenario 3a for the Kyiv Institutional Building Assessment (thousand \$)

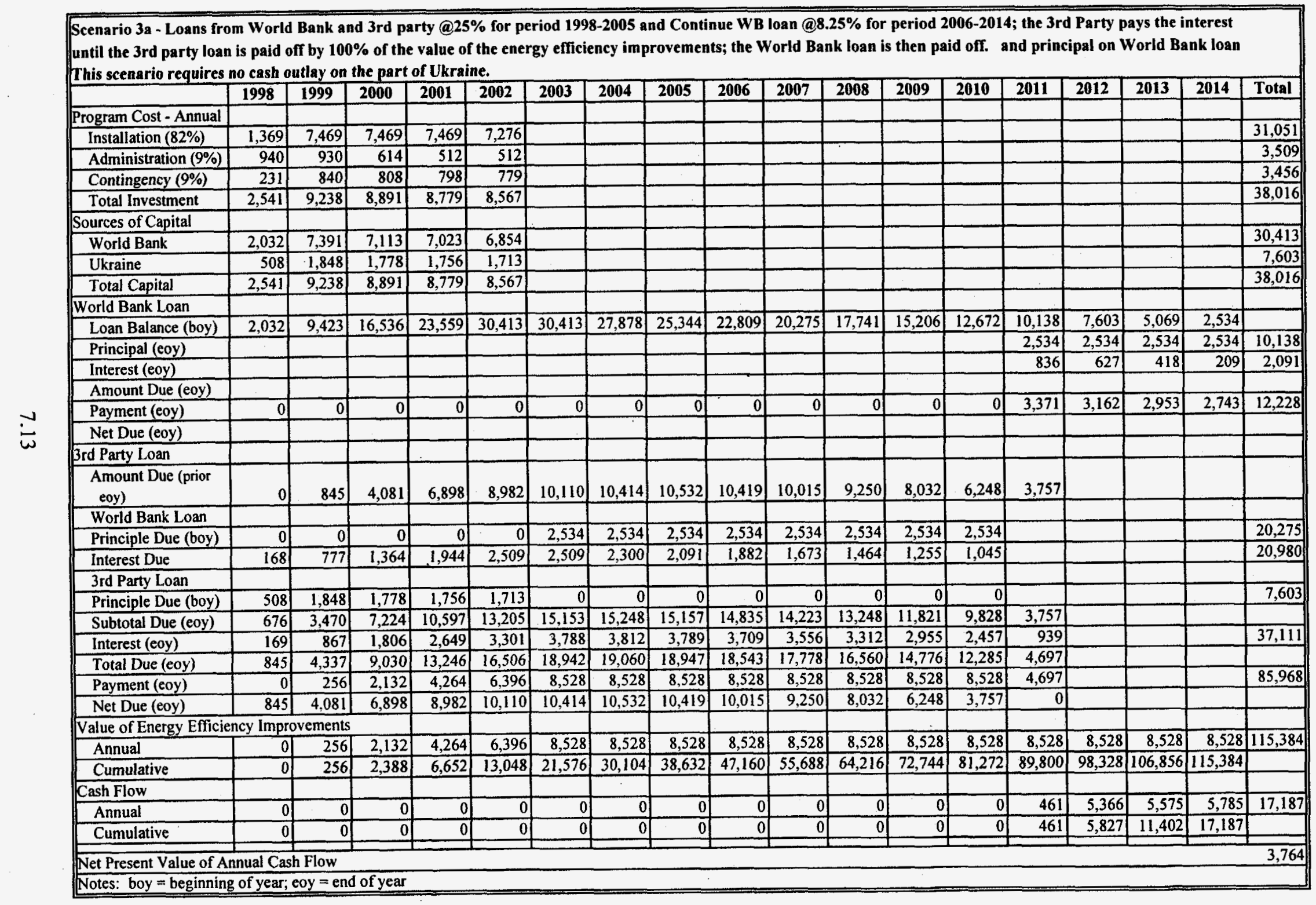




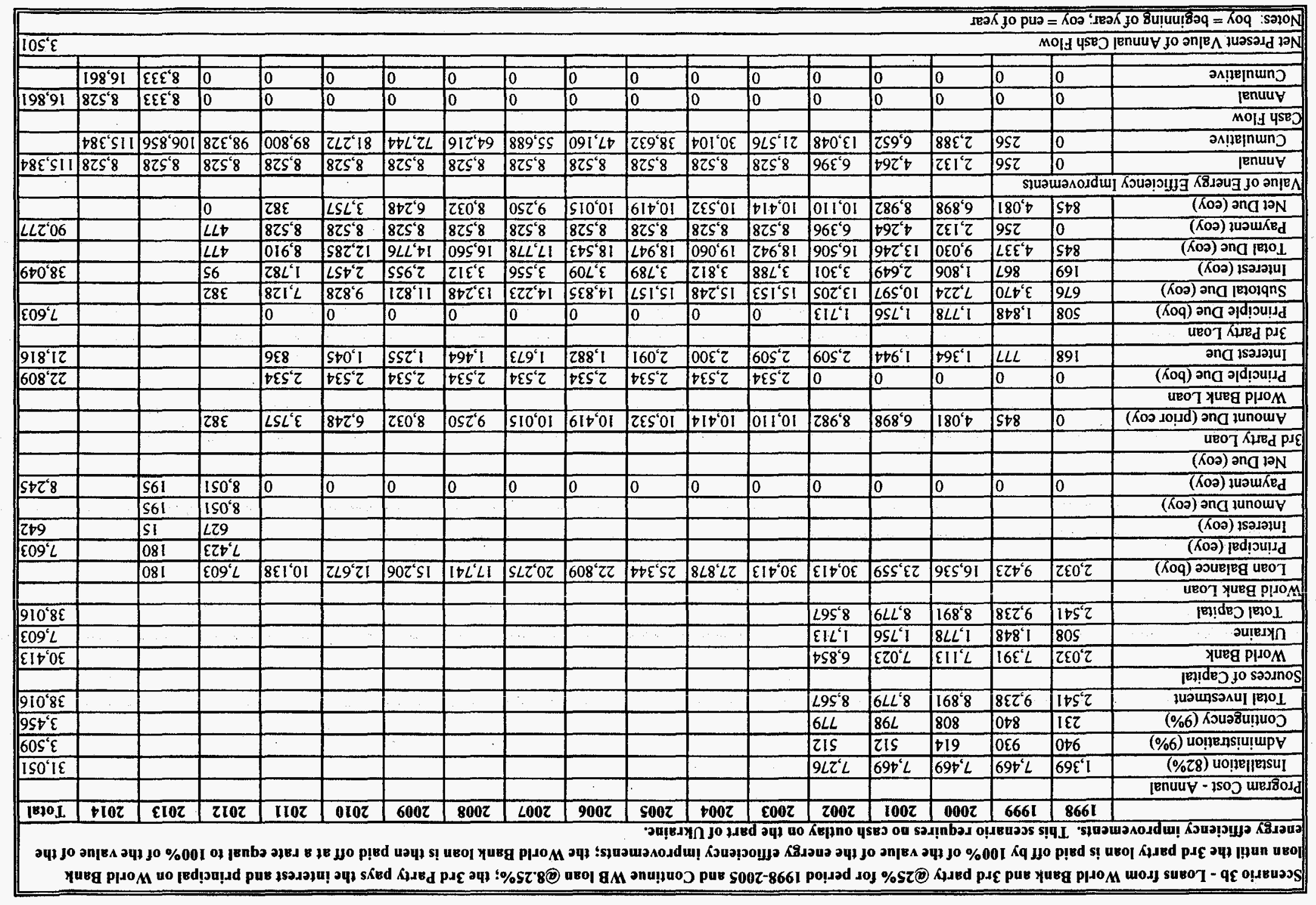


Table 7.8. Summary of Financing Scenarios 1a through $3 \mathrm{~b}$ for Potential $\$ 40$ Million Kyiv Institutional Building Assessment Project

\begin{tabular}{|c|c|c|c|c|c|c|c|}
\hline $\begin{array}{l}\text { Scenario/ } \\
\text { Variant }\end{array}$ & \multicolumn{3}{|c|}{ Financing Share } & $\begin{array}{l}\text { Cash Flow } \\
1998-2002\end{array}$ & $\begin{array}{c}\text { Net } \\
\text { Present } \\
\text { Value }\end{array}$ & $\begin{array}{c}\text { Loan } \\
\text { Outflow }\end{array}$ & $\begin{array}{l}\text { Break-even } \\
\text { Gas Price } \\
\left(\$ / 1000 \mathrm{~m}^{3}\right)\end{array}$ \\
\hline & $\begin{array}{l}\text { World } \\
\text { Bank }\end{array}$ & Ukraine & $\begin{array}{l}\text { Third } \\
\text { Party }\end{array}$ & & & & \\
\hline \multicolumn{8}{|c|}{ 1(a) - Single loan from World Bank @ 8.25\% for period 1998-2014 } \\
\hline & $80 \%$ & $20 \%$ & $0 \%$ & $\begin{array}{l}\text { - Annual maximum negative value of } \$ 2.4 \mathrm{M} \text { in } 1999 \text {. } \\
\text { - Cumulative maximum negative value of } \$ 4.1 \mathrm{M} \text { in } 2000 \text {. } \\
\text { - Positive after } 2000 \text {. }\end{array}$ & $\$ 10.0 \mathrm{M}$ & $\$ 53.5 \mathrm{M}$ & $\$ 53$ \\
\hline \multicolumn{8}{|c|}{ 1(b) - Single loan from World Bank @ 8.25\% for period 1998-2007 } \\
\hline & $80 \%$ & $20 \%$ & $0 \%$ & $\begin{array}{l}\text { Annual maximum negative value of } \$ 2.4 \mathrm{M} \text { in } 1999 \text {. } \\
\text { - Cumulative maximum negative value of } \$ 4.1 \mathrm{M} \text { in } 2000 \text {. } \\
\text { Positive in } 2001 \text { and } 2002 \text {; zero from } 2003-2006 \text {; and } \\
\text { positive after } 2006 \text {. }\end{array}$ & $\$ 16.4 \mathrm{M}$ & $\$ 44.3 \mathrm{M}$ & $\$ 44$ \\
\hline \multicolumn{8}{|c|}{ 2(a) - Loans from World Bank @ 8.25\% for period 1998-2014 and Third Party @ 25\% for period 1998-2002 } \\
\hline & $80 \%$ & $0 \%$ & $20 \%$ & $\begin{array}{l}\text { - Annual maximum negative value of } \$ 1.9 \mathrm{M} \text { in } 2001 \text {. } \\
\text { - Cumulative maximum negative value of } \$ 5.6 \mathrm{M} \text { in } 2002 \text {. } \\
\text { - Positive after } 2002 \text {. }\end{array}$ & $\$ 14.6 \mathrm{M}$ & $\$ 58.6 \mathrm{M}$ & $\$ 58$ \\
\hline \multicolumn{8}{|c|}{ 2(b) - Loans from World Bank @ 8.25\% for period 1998-2007 and Third Party @ 25\% for period 1998-2002 } \\
\hline & $80 \%$ & $0 \%$ & $20 \%$ & $\begin{array}{l}\text { - Annual maximum negative value of } \$ 1.9 \mathrm{M} \text { in } 2001 \text {. } \\
\text { - Cumulative maximum negative value of } \$ 5.6 \mathrm{M} \text { in } 2002 \text {. } \\
\text { - Zero from } 2003-2006 \text { and positive after } 2006 \text {. }\end{array}$ & $\$ 14.0 \mathrm{M}$ & $\$ 50.6 \mathrm{M}$ & $\$ 50$ \\
\hline
\end{tabular}

3(a) - Loans from World Bank @ 8.25\% for period 1998-2014 and from third party @ 25\% for period 1998-2010; third-party services World Bank loan from 1998-2010@ 25\% and Ukraine services World Bank loan @ 8.25\% from 2011-2014.

$$
\begin{array}{|c|c|c|c|c|}
\hline 80 \% & 0 \% & 20 \% & \bullet \text { Zero from } 1998-2010 \text { and positive after } 2010 . \\
\hline
\end{array}
$$

\begin{tabular}{l|l}
$\$ 3.8 \mathrm{M}$ & $\$ 98.2 \mathrm{M}$ \\
\hline
\end{tabular}

$\$ 97$

3(b) - Loans from World Bank @ 8.25\% for period 1998-2011 and from third party @ 25\% for period 1998-2010; third-party services World Bank loan from 1998-2010@25\% and Ukraine services World Bank loan @ 8.25\% in 2011.

\begin{tabular}{|c|c|c|c|c|c|c|}
\hline & $80 \%$ & $0 \%$ & $20 \%$ & $\bullet$ Zero from $1998-2012$ and positive after 2012. & $\$ 3.5 \mathrm{M}$ & $\$ 98.5 \mathrm{M}$ \\
\hline Note: Calculations are preliminary, but results are felt to be indicative of the alternate loan terms and conclusions are believed valid.
\end{tabular} 
Each scenario and variant provides key information regarding the loan. Basic conclusions that can be drawn are (while these are intuitively obvious, the analysis supports these conclusions):

- The greater the $20 \%$ share of the loan assumed by Ukraine, the greater the national benefit.

- Paying off the loan(s) faster results in an increase in the national benefit.

- It is desirable to obtain as much grant financing as possible to reduce the domestic burden.

- If third party financing is relied upon, it is desirable to obtain as low a rate as possible to maximize the national benefit. 


\subsection{Bidding/Tendering}

The World Bank has developed procedures and practices for the procurement of goods through International Competitive Bidding (ICB). This procedure is mandatory for use in projects that are financed in whole or in part by the World Bank in accordance with provisions of the document Guidelines: Procurement under IBRD Loans and IDA Credits, January 1995 edition (World Bank 1996). An alternative procurement method permitted by the World Bank is the National Competitive Bidding (NCB) procedure, which may also be used. The borrower shall use the appropriate Standard Bidding Document (SBD) (January 1995) issued by the World Bank, with minimum changes acceptable to the World Bank.

The bidding document shall furnish all information necessary for a prospective bidder to prepare a bid for providing goods and services, and at minimum the bidding document shall include: invitation to bid, instruction to bidders, form of bid, form of contract, specification and drawings, list of goods and their quantities, delivery time, and contract schedule. The basis of bid evaluation shall be clearly outlined in the instructions to the bidder.

Procurement activities will include three major categories: 1) procurement of technical and consulting services, 2) purchase of materials and components, and 3) procurement of works. The following is a description of the services, materials, and works to be procured and procurement procedure suggested for each category.

\subsection{Services Procurement}

The project implementation activities will be carried out by the PIO supported by the General Contractor (GC) responsible for installation tasks. The PIO will be the central point of the project implementation structure and will oversee all project tasks. The PIO will be responsible for all activities during the bidding process including preparation of specific bidding packages, prequalification of certain bidders, selection of bids, issuing of contracts, management of project schedule, monitoring of project implementation, acceptance of deliverables (material, labor, services), and acceptance of performance verification results. Selection of qualified PIO professional staff and consultants is crucial to the success of the project. The bidding procedure for the consultants in this category will be carried out in accordance with ICB rules. Selection of permanent staff members will be at the discretion of the borrower, providing that staff members will be on government payroll. A preliminary listing of PIO staff responsibilities is located in Appendix C, Table C.2.

In principle, the PIO can be set up as 1) a government budgetary organization charged with the project implementation, 2) an independent nongovernment agency , 3) a for-profit Procurement Agent Firm, local or foreign, or 4) a combination of the above alternatives. The number and type of procured support services will vary depending on the selected project implementation structure. 
The PIO will likely be staffed by permanent or long-term temporary personnel and will be assisted by consultants, foreign and local. Services necessary for PIO operation will be procured as short-term contracts, annual contracts, or contracts for the duration of the project. A preliminary estimate of the staff and resources required is located in Appendix C, Table C.2.

\subsection{Design, Installation, and Equipment/Materials Procurement}

The project implementation will require design and specification work. The project objective is to install energy efficiency measures into approximately 1700 buildings in the city of Kyiv. Each individual building or building complex will have to be audited, and installation drawings, parts lists, and specifications will have to be generated. These documents will then be used for preparation of bidding documents for equipment/materials and installation work.

The procurement of technical services according to NCB rules is the most appropriate method, is justified by the technical aspects of the technology, and also appears to be the most economical. The service provider must be familiar with and must comply with local practices, design requirements and certification processes, building codes, fire prevention codes, and other standards applicable to the subject project. Two alternatives for the procurement of materials and installation are provided below.

\section{Alternative 1: Turnkey installation}

Under this alternative, the bidder will provide materials and installation work. The bidder may utilize specialized firms for installation works of individual parts of the project. The job will be quoted to the GC as a package(s). Contractors will be responsible for preparation of design work, purchases of material and parts, installation work, and all the necessary miscellaneous services. The bidder shall supply material and parts according to the technical specification included in the request for proposals.

Procurement suboptions of installation under this alternative include 1) bids for individual (single) building-sized projects, 2) groups of buildings, or 3) district-wide annual contracts. Technical parameters of specific items, such as heat exchanger capacity, circulating pump performance, etc. will be determined for each specific building during the project design and will be provided to the successful bidder.

The advantage of this alternative is simplicity of procurement and better accountability for quality because of the sole responsibility arrangement. However, this alternative has several disadvantages, among which the most important are 1) difficulty recognizing the difference in quality of materials and difficulty recognizing the level of labor intensity required for installation of different components that may be suggested by the bidder, 2) difficulty enforcing the purchase of best-quality and bestperformance components, as contractors under this arrangement tend to be driven by the lowest installation cost. If this approach is used, attention to the bidding specifications will help to mitigate these difficulties. 


\section{Alternative 2: Separate procurement of material and labor.}

In this alternative, the PIO would organize the material procurements and installation work separately. Material will be purchased for all buildings in batches sized according to a current need or will be purchased on stock. Procurement of material would precede the procurement of work. Bidders will then be required to submit requests for materials from the warehouse according to the technical specification of the job site. Installation of some components/systems may require that the installer is certified by the manufacturer. The material/quantity would be specified for each project/building by the drawings and specification. Utilization of specified material and correctness of installation will be checked and approved (signed off) by the QA team.

Advantages of this alternative are 1) better control over material selection and purchases by the PIO, 2) better position in negotiating prices with suppliers for higher volume purchases, 3) use of standard components throughout the system, resulting in easier maintenance, easier training process, and lower number of stocked spare parts, and 4) potentially easier importing procedure for foreign components.

Disadvantages include 1) no single source of responsibility, which may result in difficulty resolving quality problems, 2) more complex procurement procedure, 3) possible need for stocking the materials, and 4) different procurement rules for materials and work may apply.

\subsubsection{Installation}

Because of the complex nature of the project, prequalification of contractors providing the installation work is essential. The prequalification process will be done by the PIO prior to loan negotiation and will follow procedures set forth in the Guidelines (World Bank 1996). A list of qualified contractors will be periodically updated by the PIO for the duration of the project. Prequalification of contractors will be based on evaluation of their capability and resources necessary for performing the work. A Standard Prequalification Document prepared by the World Bank will be used. Requests for proposals (RFP) will be sent only to the qualified bidders to avoid unnecessary expenses by the PIO and the bidders.

The procurement of work will be organized in such manner that multiple contracts will be issued in each category of applied technology. The number of contracts issued in each category will depend on the technology and quantity of the work within a given installation period. Large contracts to a single bidder shall be avoided to maintain a proper level of competitiveness and minimize nondelivery risk. It is expected that at minimum two contractors in each technology category (substations, weatherization, insulation) will be involved at each time.

As mentioned earlier, this project will involve the retrofit of 1700 buildings over a period of 4 years. Each building has a specific layout and is anticipated to require different sizes of equipment, quantities of material, and amount of installation labor. It would be inefficient and costly to request bids for individual buildings or require bidders to provide complex bids for several hundred buildings. 
Therefore, it is desirable to use a two-stage bidding process. In the first stage, unpriced proposals on the basis of conceptual design will be invited, and bids received will be subjected to technical and commercial clarifications and adjustments followed by amended bidding documents and submission of final technical proposals. In the second stage, selected bidders in each technology category will be invited to provide cost proposals for individual installation sites (single buildings or group of buildings). Fixed-cost Work Orders (WOs) will be issued by the GC for each site or group of sites according to the installation schedule over the duration of the project.

The most efficient method of procuring work of this project's nature is the NCB procedure, which is recognized as an alternative procurement method by the Guidelines (World Bank 1996). This procurement method is recommended for the following reasons: 1) the contract value for individual projects may not be attractive to foreign companies to perform the work in Ukraine, mainly due to high costs associated with travel and long-term accommodation of workers in a foreign country, 2) the project may be difficult to perform due to specific problems such as language barriers, compliance with local licensing requirements, etc., and most importantly, 3) because of the competitiveness of labor and overhead costs.

\subsubsection{Procurement of Materials}

Prequalification of suppliers of some specific equipment and materials is essential and will be accomplished prior to loan negotiations, following the procedure set forth in the Guidelines (World Bank 1996). A standard prequalification document prepared by the bank will be used. A list of qualified suppliers will be periodically updated for the duration of the project. Prequalification of equipment suppliers will be based on technical parameters, suitability for the project, availability of replacement parts, and availability of equipment service in Ukraine.

Whenever possible, equipment and materials will be purchased from different suppliers to 1) eliminate dependency on a single supplier's commitment, 2) ensure timely delivery, and 3) maintain competitiveness of prices. It is expected that at least two suppliers of weatherization and insulation material and at least two suppliers of substation technology will be selected.

The project also involves materials available from multiple sources in several member countries. Some of the involved materials are off-the-shelf types, which can be accurately specified. Part of the material involves specialized equipment produced by different producers in different countries. Under such circumstances, the most appropriate method of procurement of material is International Shopping (IS), which requires obtaining at minimum three competitive quotes for substantially similar material or equipment from at least two different countries. Obtaining general quotes for different sizes of equipment and/or for different quantities of material is relatively simple, and requests for quotes for material required for the first year's installation will be prepared prior to loan negotiation.

The following is a brief description of the anticipated material and equipment to be procured during the project. 


\section{Substation Retrofit Equipment: (ICB)}

Substation retrofit will require the purchase of parts and equipment such as heat exchangers, pumps, controls, and other components that are available from multiple sources/manufacturers in several countries. Prepackaged substations are also available from several manufacturers in various countries. If a prepackaged option is selected, materials will be procured according to the IS procedure. Should the material be purchased individually and field assembled, a margin of preference of $15 \%$ for domestically produced goods will be requested for approval by the World Bank for specific items of the assembly such as valves, black pipes, welding material, and hardware supply. The $15 \%$ margin of preference is requested for these materials because they are readily available locally with potential benefits such as lower cost, positive impacts on the local economy, and generally easier access to the materials.

The total amount of material planned for procurement in this category represents $\$ 12,078$ thousand. Material for which the margin of preference may be requested represents $\$ 1,812$, or $15 \%$ of the total investment in this procurement category.

\section{Weatherstripping Material (ICB)}

Weatherstripping material consists of a polyethylene or polycarbonate-based V-seal, "P" type EPDM-seal, and silicone material in tubes. All of these materials are available in generally good quality from a variety of manufacturers in several countries. Procurement under IS rules is the most appropriate. If any of the materials are not available domestically, local bidders should be encouraged to form joint ventures with foreign manufacturers, and a margin of preference of $15 \%$ will be requested from the World Bank for products manufactured and offered domestically by such joint ventures.

The total amount of material planned for procurement in this category represents $\$ 2,159$ thousand.

\section{Reflectors for Radiators}

Heat reflecting material is available in continuous 1.2-meter-wide rolls from several manufacturers with several design variations. Acceptable material shall have a heat insulation layer and high reflectivity surface. Both plastic and metal materials are acceptable.

Procurement under IS rules is the most appropriate. If the material is not available domestically, local bidders should be encouraged to form joint ventures with foreign manufacturers, and a margin of preference of $15 \%$ will be requested from the World Bank for products manufactured and offered domestically by such joint ventures.

The total amount of material planned for procurement in this category represents $\$ 1,176$ thousand. 


\section{Hot Water Heat Exchanger}

Domestic hot water heat exchangers may be designed as through-flow heat exchangers with capacity equal to the domestic water heating peak requirement, or with hot water storage and a lower capacity heat exchanger. Both systems are acceptable for application in institutional and residential buildings. These systems may be assembled from individually purchased components available from multiple sources/manufacturers, or they can be purchased as a packaged system. Such systems are available from various manufacturers. If a prepackaged option is selected, the material will be procured under the IS procedure. Should the material and components be purchased individually and field assembled, a margin of preference of $15 \%$ for domestically produced goods will be requested for approval by the World Bank for specific items of the assembly, such as valves, black pipe, welding materials, and other hardware supply.

The total amount of material planned for procurement in this category represents $\$ 2,933$ thousand. Material for which the margin of preference may be requested represents $\$ 587$ thousand, or $20 \%$ of total investment in this procurement category.

\section{Low-flow Showerheads}

Energy and water-saving showerheads are available in many design variations and connection sizes. Most applications will require a connection size of $1 / 2$ inch. Simple design, solid brass or highperformance plastic showerheads with maximum flow of $7.5 \mathrm{l} / \mathrm{min}$ of water are acceptable. Such showerheads are available from local and foreign manufacturers, and procurement under the IS rules is the most appropriate. Local bidders will be encouraged to form joint ventures with foreign manufacturers to introduce high-performance products to local markets, and a margin of preference of $15 \%$ will be requested from the World Bank for products manufactured and offered domestically by such joint ventures.

The total amount of material planned for procurement in this category represents $\$ 133$ thousand.

\section{Aerators}

Energy and water-saving aerators for lavatory and kitchen faucets in institutional buildings utilize orifice and aerating effects to reduce the water flow for running water consumption. Aerators are made in several design variations and connection sizes to fit existing hardware. Most applications will require a connection size of $1 / 2$ inch. Simple design, solid brass or high-performance plastic heads with maximum flow of $10 \mathrm{l} / \mathrm{min}$ of water are acceptable. Aerators are available from local and foreign manufacturers and procurement under IS rules is the most appropriate. Local bidders will be encouraged to form joint ventures with foreign manufacturers to introduce high-performance products to local markets, and a margin of preference of $15 \%$ will be requested from the World Bank for products manufactured and offered domestically by such joint ventures. 
The total amount of material planned for procurement in this category represents $\$ 178$ thousand.

\section{Ceiling Fans}

Ceiling fans are available in many design variations, technical parameters, and sizes. Most applications will require low-speed, large-diameter blade ceiling fans with $220 \mathrm{~V}, 50 \mathrm{~Hz}$, shaded pole motors of less than $40 \mathrm{~W}$ power input. Such ceiling fans are available from local and foreign suppliers and will be procured under IS rules. Local bidders will be encouraged to form joint ventures with foreign manufacturers to introduce such products to local markets, and a margin of preference of $15 \%$ will be requested from the World Bank for products manufactured and offered domestically by such joint ventures.

The total amount of material planned for procurement in this category represents $\$ 57$ thousand.

\section{Building Level Heat Meter}

Metering devices, including all necessary parts used for measurement, monitoring of consumption, billing, and other similar purposes must be certified by the Ukrainian Office of Measurement and Standards. Bidders will be requested to offer certified equipment for use in Ukraine or secure certification of such equipment prior to bidding. Bidders must provide the certification document with the bid.

Heat meters are available from local and foreign manufacturers, and this material will be procured without exception under the IS rules.

The total amount of material planned for procurement in this category represents $\$ 4,698$ thousand.

Table 8.1 provides a summary of estimated material requirements and material and labor costs with the cost information shown for domestic and foreign sources. 
Table 8.1. Summary of Estimated Material Requirements and Material and Labor Costs

\begin{tabular}{|l|c|r|r|r|r|r|r|r||}
\hline \multicolumn{1}{|c|}{ Item } & Units & Quantity & $\begin{array}{c}\text { Material } \\
\text { Cost (\$) }\end{array}$ & $\begin{array}{r}\text { Domestic } \\
\text { Material } \\
\text { Supply }\end{array}$ & $\begin{array}{c}\text { Labor } \\
\text { Cost (\$) }\end{array}$ & Domestic (\$) & Foreign (\$) & $\begin{array}{c}\text { Total } \\
\text { Cost (\$) }\end{array}$ \\
\hline Reflectors & Each & 227,894 & $1,175,931$ & $0 \%$ & 890,051 & 374,759 & 515,293 & $2,065,983$ \\
\hline Weatherstripping & Meters & $2,399,006$ & $2,159,105$ & $0 \%$ & $2,532,284$ & $1,066,225$ & $1,466,059$ & $4,691,389$ \\
\hline $\begin{array}{l}\text { Ceiling Fans } \\
\text { Substation } \\
\text { Controls }\end{array}$ & Each & 347 & 56,565 & $0 \%$ & 13,881 & 4,338 & 9,543 & 70,446 \\
\hline $\begin{array}{l}\text { Hot Water Heat } \\
\text { Exchanger }\end{array}$ & Each & 1,678 & $12,077,737$ & $20 \%$ & $3,053,729$ & 954,290 & $2,099,439$ & $15,131,465$ \\
\hline Showerheads & Each & 17,313 & 133,069 & $100 \%$ & 45,687 & 19,237 & 26,451 & 178,756 \\
\hline Aerators & Each & 59,345 & 178,035 & $100 \%$ & 93,963 & 39,563 & 54,399 & 271,997 \\
\hline Heat Meters & Each & 1,678 & $4,698,400$ & $100 \%$ & 268,480 & 83,900 & 184,580 & $4,966,880$ \\
\hline Total & & & $23,411,408$ & & $7,639,544$ & $2,774,020$ & $4,865,524$ & $31,050,952$ \\
\hline
\end{tabular}




\subsection{References}

Cabinet of Ministers of Ukraine. 1992. “On Ukraine's Entering the International Monetary Fund, International Bank for Reconstruction and Development, International Financial Corporation, International Development Association, and Multilateral Agency for Investment Guarantees," Decree \#2402 of June 3, 1992, Cabinet of Ministers of Ukraine, Kyiv, Ukraine.

Cabinet of Ministers of Ukraine. 1993. "On Sovereign Guarantees for Foreign Loans Given to Ukraine under International Agreements," Decree \#25-93 of March 17, 1993, Cabinet of Ministers of Ukraine, Kyiv, Ukraine.

Cabinet of Ministers of Ukraine. 1996a. "On Program for Stopping the Production and Use of OzoneDepleting Substances in Ukraine," Decree \#1274 of October 17, 1996, Cabinet of Ministers of Ukraine, Kyiv, Ukraine.

Cabinet of Ministers of Ukraine. 1996b. "On Procedure of Compensating for the State Budget Losses That Resulted from Occurrence of Events Guaranteed Against in Agreements On Foreign Loans Received by Ukrainian Legal Persons Under Guarantees of the Government of Ukraine," Decree \#1002 of December 14, 1996, Cabinet of Ministers of Ukraine, Kyiv, Ukraine.

Cabinet of Ministers of Ukraine. 1996c. "On Procedure of Preparing and Implementing Ukraine Economy Development Projects Supported by the International Bank for Reconstruction and Development," Decree \#440 of April 18, 1996, Cabinet of Ministers of Ukraine, Kyiv, Ukraine.

Cabinet of Ministers of Ukraine. 1997. "On Streamlining Attraction and Use of Foreign Credits the Repayment of Which is Guaranteed by the Cabinet of Ministers of Ukraine, Improvement of the System of Financial Resources Attraction and External State Debt Servicing," Decree \#414 of May 1997, Cabinet of Ministers of Ukraine, Kyiv, Ukraine.

Ekono Energy. 1996. Feasibility Study for Heat Supply and Energy Efficiency Project Kiev. Ekono Energy, Ukraine, Finland.

International Energy Agency (IEA). 1996. Energy Policies of Ukraine: 1996 Survey, Organization for Economic Cooperation and Development, International Energy Agency, Paris, France.

Joseph Technology Corporation (JTC). 1996. Ukraine Kiev District Heating Project. Joseph Technology Corporation, Woodcliff Lake, New Jersey.

Law of Ukraine. 1991. On Protection of Natural Environment, Decree \#1268-12 of June 26, 1991, Parliament of Ukraine, Kyiv, Ukraine. With changes introduced by the Laws \#3180-12 of May 5, 1993, and \#81/96-BP of March 6, 1996, Parliament of Ukraine, Kyiv, Ukraine. 
Law of Ukraine. 1992. On Protection of Ambient Air, Decree \#2708-12 of October 16, 1992, Parliament of Ukraine, Kyiv, Ukraine. With changes introduced by the Law \#75/95-BP of February 28, 1995, Parliament of Ukraine, Kyiv, Ukraine.

Pacific Northwest National Laboratory (PNNL). 1997. Kyiv Institutional Buildings Sector Energy Efficiency Program: Technical Assessment, PNNL-11644, Pacific Northwest National Laboratory, Richland, Washington.

State Committee of Ukraine on Affairs of Urban Development and Architecture. 1996. SNiP 2.04.05-91*U, Heating, Ventilation and Air Conditioning, Order \#117 of June 27, 1996, State Committee of Ukraine on Affairs of Urban Development and Architecture, Kyiv, Ukraine.

TACIS. 1994. Study of the Potential for Developing Actions to Improve the Overall Energy Efficiency in the Building Sector in Ukraine, Commission of European Communities by Sogelberg Ingeniere, and TechInvest, Lisbon, Portugal.

United States Department of Energy (DOE). 1995. Emissions of Greenhouse Gases in the United States: 1987-1994, DOE/EIA-0573(87-94), U.S. Department of Energy, Energy Information Administration, Washington, D.C.

United States Department of Energy (DOE). 1996. North American Energy Measurement and Verification Protocol, DOE/EE-0081, U.S. Department of Energy, Washington, D.C.

World Bank. 1991. Operational Directive 4.01: Environmental Assessment, The World Bank Operational Manual, World Bank, Washington, D.C.

World Bank. 1996. Guidelines: Procurement under IBRD Loans and IDA Credits, January 1995 edition, World Bank, Washington, D.C. 
Appendix A

Institutional Buildings Detailed Technical Assessment Data 


\section{Appendix A}

\section{Institutional Buildings Detailed Technical Assessment Data}

Detailed results from the technical assessment of the institutional buildings sector are presented in this appendix. Tables A.1 and A.2 present the institutional building stock estimates by number of buildings and floorspace for each of the building categories. Table A.3 presents the estimated baseline energy consumption for this building stock. Table A.4 presents the list of ECOs considered for application to the building stock, including the labor and material costs for these ECOs. Table A.5 presents the estimated cost-effective energy efficiency potential for each building category in Gcal/year. Finally, Table A.6 presents the required investment levels to acquire the efficiency resource. 
Table A.1. Number of Buildings by Vintage and Size

\begin{tabular}{|c|c|c|c|c|c|c|c|c|c|c|}
\hline \multirow{3}{*}{$\begin{array}{l}\text { Institutional Building } \\
\text { Owner and Category }\end{array}$} & \multicolumn{10}{|c|}{ Number of Buildings by Vintage and Size } \\
\hline & \multicolumn{3}{|c|}{ Pre-1958 } & \multicolumn{3}{|c|}{$1958-1980$} & \multicolumn{3}{|c|}{\begin{tabular}{|l} 
Post-1980 \\
\end{tabular}} & \multirow{2}{*}{$\begin{array}{l}\text { Total Number } \\
\text { of Buildings }\end{array}$} \\
\hline & $<3$ Stories & 3-4 Stories & $>4$ Stories & $<3$ Stories & 3-4 Stories & $>4$ Stories & $<3$ Stories & 3-4 Stories & $>4$ Stories & \\
\hline \multicolumn{11}{|l|}{ Municipal Dept. of Health } \\
\hline Hospitals & 41 & 26 & 5 & 12 & 22 & 30 & 3 & 2 & 19 & 160 \\
\hline Polyclinics & 25 & 8 & 1 & 10 & 22 & 3 & 4 & 14 & 23 & 110 \\
\hline Administration & 34 & 2 & 1 & 13 & 5 & 4 & 3 & 3 & 4 & 69 \\
\hline Subtotal & 100 & 36 & 7 & 35 & 49 & 37 & 10 & 19 & 46 & 339 \\
\hline \multicolumn{11}{|l|}{ Municipal Dept. of Ed. } \\
\hline Kindergartens & 43 & $\overline{1}$ & $\overrightarrow{0}$ & 375 & 0 & 0 & 153 & 28 & 0 & 600 \\
\hline Schools & 7 & $\overline{95}$ & 0 & 11 & 185 & 0 & 7 & 84 & 0 & 389 \\
\hline Subtotal & 50 & 96 & 0 & 386 & 185 & 0 & 160 & 112 & 0 & 989 \\
\hline \multicolumn{11}{|l|}{ Ministry of Education } \\
\hline Education Buildings & 4 & 32 & 5 & 9 & 43 & 48 & 4 & 7 & 22 & 174 \\
\hline Hostels & 2 & 6 & 7 & 2 & 5 & 97 & 0 & 0 & 14 & 133 \\
\hline Subtotal & 6 & 38 & 12 & 11 & 48 & 145 & 4 & 7 & 36 & 307 \\
\hline \multicolumn{11}{|l|}{ Municipal Dept. of Culture } \\
\hline Theaters & 0 & 8 & 1 & 2 & 0 & 0 & 0 & 0 & 1 & 12 \\
\hline Art Galleries/Museums & 17 & 8 & 1 & 0 & 0 & 1 & 3 & 1 & 0 & 31 \\
\hline Subtotal & 17 & 16 & 2 & 2 & 0 & 1 & 3 & 1 & 1 & 43 \\
\hline & & & & & & & & & & \\
\hline Total & & & & & & & & & & 1,678 \\
\hline
\end{tabular}


Table A.2. Floorspace of Buildings by Vintage and Size $\left(\mathrm{m}^{2}\right)$

\begin{tabular}{|c|c|c|c|c|c|c|c|c|c|c|}
\hline \multirow{3}{*}{$\begin{array}{l}\text { Institutional Building } \\
\text { Owner and Category }\end{array}$} & \multicolumn{10}{|c|}{ Floorspace of Buildings by Vintage and Size $\left(\mathrm{m}^{2}\right)$} \\
\hline & \multicolumn{3}{|c|}{ Pre-1958 } & \multicolumn{3}{|c|}{\begin{tabular}{|c|}
$1958-1980$ \\
\end{tabular}} & \multicolumn{3}{|c|}{$\begin{array}{r}\text { Post-1980 } \\
\end{array}$} & \multirow{2}{*}{$\begin{array}{l}\text { Floorspace } \\
\text { of Building }\end{array}$} \\
\hline & $<3$ Stories & 3-4 Stories & $>4$ Stories & $<3$ Stories & 3-4 Stories & $>4$ Stories & $<3$ Stories & 3-4 Stories & $>4$ Stories & \\
\hline \multicolumn{11}{|l|}{ Municipal Dept. of Health } \\
\hline Hospitals & 58,026 & 58,475 & 15,492 & 12,437 & 61,374 & 191,483 & 10,357 & 12,863 & 216,618 & 637,125 \\
\hline Polyclinics & 24,340 & 9,775 & 1,300 & 6,715 & 50,886 & 12,757 & 2,876 & 51,462 & 133,756 & 293,867 \\
\hline Administration & 19,219 & 2,487 & 3,100 & 9,189 & 8,735 & 16,022 & 2,420 & 6,261 & 24,812 & 92,245 \\
\hline Subtotal & 101,585 & 70,737 & 19,892 & 28,341 & 120,995 & 220,262 & 15,653 & 70,586 & 375,186 & $1,023,237$ \\
\hline \multicolumn{11}{|l|}{ Municipal Dept. of Ed. } \\
\hline Kindergartens & 47,867 & 1,427 & $\mathbf{0}$ & 732,806 & 0 & 0 & 431,920 & 98,306 & 0 & $1,312,326$ \\
\hline Schools & 12,792 & 531,414 & 0 & 19,409 & $1,419,251$ & 0 & 19,987 & 801,415 & 0 & $2,804,268$ \\
\hline Subtotal & 60,659 & 532,841 & 0 & 752,215 & $1,419,251$ & $\overline{0}$ & 451,907 & 899,721 & 0 & $4,116,594$ \\
\hline \multicolumn{11}{|l|}{ Ministry of Education } \\
\hline Education Buildings & 18,648 & 182,982 & 26,924 & 19,965 & 236,144 & 430,404 & 11,664 & 51,559 & 250,475 & $1,228,765$ \\
\hline Hostels & 8,722 & 26,899 & 31,525 & 3,840 & 39,189 & 539,789 & & & 80,650 & 730,614 \\
\hline Subtotal & 27,370 & 209,881 & 58,449 & 23,805 & 275,333 & 970,193 & 11,664 & 51,559 & 331,125 & $1,959,379$ \\
\hline \multicolumn{11}{|l|}{ Municipal Dept. of Culture } \\
\hline Theaters & 0 & 38,470 & 2,700 & 3,453 & 0 & 0 & 0 & 0 & 3,420 & 48,043 \\
\hline Art Galleries/Museums & 18,334 & 15,159 & 5,380 & 0 & 0 & 20,000 & 3,585 & 2,900 & 0 & 65,358 \\
\hline Subtotal & 18,334 & 53,629 & 8,080 & 3,453 & 0 & 20,000 & 3,585 & 2,900 & 3,420 & 113,401 \\
\hline Total & & & & & & & & & & $7,212,611$ \\
\hline
\end{tabular}


Table A.3. Baseline Annual Energy Consumption (space heat and hot water)

\begin{tabular}{|c|c|c|c|c|c|c|c|c|c|c|}
\hline \multirow[b]{3}{*}{$\begin{array}{l}\text { Institutional Building } \\
\text { Owner and Category }\end{array}$} & \multicolumn{10}{|c|}{ Baseline Energy Consumption of Buildings by Vintage and Size (Gcal) } \\
\hline & \multicolumn{3}{|c|}{ Pre-1958 } & \multicolumn{3}{|c|}{\begin{tabular}{|c|}
$1958-1980$ \\
\end{tabular}} & \multicolumn{3}{|c|}{$\begin{array}{l}\text { Post-1980 } \\
\end{array}$} & \multirow{2}{*}{$\begin{array}{c}\text { Energy } \\
\text { Consumption } \\
\text { (Gcal) }\end{array}$} \\
\hline & $<3$ Stories & 3-4 Stories & $>4$ Stories & $<3$ Stories & 3-4 Stories & $>4$ Stories & $<3$ Stories & 3-4 Stories & $>4$ Stories & \\
\hline \multicolumn{11}{|l|}{ Municipal Dept. of Health } \\
\hline Hospitals & 11,783 & 9,778 & 2,591 & 3,763 & 18,572 & 53,368 & 3,134 & 3,022 & 50,886 & 637,125 \\
\hline Polyclinics & 3,954 & 1,588 & 211 & 1,626 & 12,318 & 2,601 & 696 & 10,491 & 25,136 & 293,867 \\
\hline Administration & 2,602 & 337 & 420 & 2,220 & 1,623 & 2,977 & 585 & 1,163 & 3,886 & 92,245 \\
\hline Subtotal & 18,338 & 11,703 & 3,221 & 7,608 & 32,513 & 58,945 & 4,415 & 14,676 & 79,908 & $1,023,237$ \\
\hline \multirow{2}{*}{\multicolumn{11}{|c|}{ Municipal Dept. of Ed. }} \\
\hline & & & & & & & & & & \\
\hline Kindergartens & 7,290 & 217 & 0 & 199,132 & 0 & 0 & 99,313 & 22,604 & 0 & $1,312,326$ \\
\hline Schools & 1,566 & 65,062 & 0 & 3,651 & 267,000 & 0 & 3,223 & 129,230 & 0 & $2,804,268$ \\
\hline Subtotal & 8,856 & 65,279 & 0 & 202,783 & 267,000 & 0 & 102,536 & 151,833 & 0 & $4,116,594$ \\
\hline \multicolumn{11}{|l|}{ Ministry of Education } \\
\hline Education Buildings & 2,840 & 27,867 & 4,100 & 5,425 & 64,170 & 80,971 & 2,682 & 11,855 & 40,390 & $1,228,765$ \\
\hline Hostels & 1,837 & 5,665 & 6,639 & 809 & 8,253 & 113,672 & 0 & 0 & 16,984 & 730,614 \\
\hline Subtotal & 4,677 & 33,532 & 10,739 & 6,234 & 72,422 & 194,643 & 2,682 & 11,855 & 57,373 & $1,959,379$ \\
\hline \multicolumn{11}{|l|}{ Municipal Dept. of Culture } \\
\hline Theaters & 0 & 7,694 & 540 & 1,054 & 0 & 0 & 0 & 0 & 792 & 48,043 \\
\hline Art Galleries/Museums & 2,895 & 2,394 & 849 & 0 & 0 & 4,632 & 830 & 672 & 0 & 65,358 \\
\hline Subtotal & 2,895 & 10,088 & 1,389 & 1,054 & 0 & 4,632 & 830 & 672 & 792 & 113,401 \\
\hline & & & & & & & & & & \\
\hline Total & & & & & & & & & & $7,212,611$ \\
\hline
\end{tabular}


Table A.4. Cost Data for Efficiency Measures

\begin{tabular}{|c|c|c|c|c|c|c|c|c|}
\hline \multirow{3}{*}{$\begin{array}{l}\text { Measure } \\
\text { Category/Description }\end{array}$} & \multicolumn{2}{|c|}{ Equipment } & \multicolumn{5}{|c|}{ Labor } & \multirow{3}{*}{$\begin{array}{l}\text { Total Cost } \\
\text { Per Unit } \\
\text { Installed (\$) }\end{array}$} \\
\hline & \multirow[b]{2}{*}{ Unit } & \multirow{2}{*}{$\begin{array}{l}\text { Per Unit } \\
\text { Cost (\$) }\end{array}$} & \multicolumn{2}{|c|}{ Hours/Unit } & \multirow{2}{*}{$\frac{\text { Ratio }}{\text { Dom./For. }}$} & \multicolumn{2}{|c|}{ Cost/Unit (\$) ${ }^{(2)}$} & \\
\hline & & & Domestic & Foreign & & Domestic & Foreign & \\
\hline \multicolumn{9}{|l|}{ Envelope } \\
\hline Exterior Side Walls & $\mathrm{m}^{2}$ & 10.50 & 0.92 & 0.18 & 5 & 4.58 & 10.08 & 25.17 \\
\hline Roof Insulation & $\mathrm{m}^{2}$ & 23.41 & 0.28 & 0.06 & 5 & 1.42 & 3.12 & 27.94 \\
\hline Attic Insulation & $\mathrm{m}^{2}$ & 6.45 & 0.31 & 0.06 & 5 & 1.54 & 3.39 & 11.38 \\
\hline Basement Floor Insulation & $\overline{m^{2}}$ & 6.00 & 0.10 & 0.02 & 5 & 0.50 & 1.10 & 7.59 \\
\hline Weatherstrip Windows and Doors & $\mathrm{m}$ & 0.90 & 0.09 & 0.01 & 8 & 0.44 & 0.61 & 1.96 \\
\hline Storm Windows and Weatherstripping & each & 60.00 & 4.17 & 0.83 & 5 & 20.83 & 45.83 & 127 \\
\hline High Perf. Glass and Weatherstripping & $\mathrm{m}^{2}$ & 24.50 & 1.17 & 0.23 & 5 & 5.83 & 12.83 & 43.17 \\
\hline Third Window Pane & $\mathrm{m}^{2}$ & 13.00 & 1.11 & 0.22 & 5 & 5.53 & 12.16 & 30.68 \\
\hline Radiator Heat Reflectors & each & 5.16 & 0.33 & 0.04 & 8 & 1.64 & 2.26 & 9.07 \\
\hline \multicolumn{9}{|l|}{ Air Handling } \\
\hline Ceiling Fans & per fan & 163 & 2.50 & 0.50 & 5 & 12.50 & 27.50 & 203 \\
\hline Ventilation Heat Recovery & $\mathrm{m}^{3} / \mathrm{hr}$ & 2.20 & 0.03 & 0.01 & 5 & 0.13 & 0.28 & 2.60 \\
\hline \multicolumn{9}{|l|}{ Domestic Water Heating } \\
\hline Hot Water Heat Exchanger (weighted average) & bldg. & 1,748 & 27.62 & 5.52 & 5 & 138 & 304 & 2,190 \\
\hline Storage Water Heater & bldg. & 2,480 & 41.67 & 8.33 & 5 & 208 & 458 & 3,147 \\
\hline Low-Flow Showerheads & each & 7.69 & 0.22 & 0.03 & 8 & 1.11 & 1.53 & 10.32 \\
\hline Faucet Aerators & each & 3.00 & 0.13 & 0.02 & 8 & 0.67 & 0.92 & 4.58 \\
\hline Apartment-Level Meters & each & 95 & 2.50 & 0.50 & 5 & 12.50 & 27.50 & 135 \\
\hline Insulate Pipes & $\mathrm{m}$ & 3.30 & 0.17 & 0.03 & 5 & 0.85 & 1.87 & 6.02 \\
\hline \multicolumn{9}{|l|}{ Heating System } \\
\hline Building-Level Meters & each & 2,800 & 10.00 & 2.00 & 5 & 50 & 110 & 2,960 \\
\hline Retrofit Heating System (weighted average) & bldg. & 7,198 & 114 & 22.75 & 5 & 569 & 1,251 & 9,018 \\
\hline Radiator Balancing Valves & each & 14.25 & 0.83 & 0.17 & 5 & 4.17 & 9.17 & 27.58 \\
\hline
\end{tabular}


Table A.5. Energy Savings (Gcal/year)

\begin{tabular}{|c|c|c|c|c|c|c|c|c|c|c|}
\hline \multirow{3}{*}{$\begin{array}{l}\text { Institutional Building } \\
\text { Owner and Category }\end{array}$} & \multicolumn{10}{|c|}{ Efficiency Potential of Buildings by Vintage and Size (Gcal/year) } \\
\hline & \multicolumn{3}{|c|}{ Pre-1958 } & \multicolumn{3}{|c|}{\begin{tabular}{|c|}
$1958-1980$ \\
\end{tabular}} & \multicolumn{3}{|c|}{ Post-1980 } & \multirow{2}{*}{$\begin{array}{c}\text { Total Efficiency } \\
\text { Potential }\end{array}$} \\
\hline & $<3$ Stories & 3-4 Stories & $>4$ Stories & $<3$ Stories & 3-4 Stories & $>4$ Stories & $<3$ Stories & 3-4 Stories & $>4$ Stories & \\
\hline \multicolumn{11}{|l|}{ Municipal Dept. of Health } \\
\hline Hospitals & 2,923 & 2,432 & 644 & 953 & 4,702 & 13,790 & 793 & 795 & 13,393 & 40,426 \\
\hline Polyclinics & 1,024 & 411 & 55 & $\overline{446}$ & 3,379 & 713 & 191 & 2,878 & 6,876 & 15,974 \\
\hline Administration & 613 & 79 & 99 & 549 & 446 & 819 & 144 & 320 & 1,079 & 4,148 \\
\hline Subtotal & 4,560 & 2,923 & 798 & 1,947 & 8,527 & 15,322 & 1,129 & 3,993 & 21,349 & 60,548 \\
\hline \multicolumn{11}{|l|}{ Municipal Dept. of Ed. } \\
\hline Kindergartens & 1,792 & 53 & 0 & 51,983 & 0 & 0 & 26,258 & 5,976 & 0 & 86,063 \\
\hline Schools & 428 & 17,791 & 0 & 994 & 72,677 & 0 & 898 & 36,016 & $\overline{0}$ & 128,805 \\
\hline Subtotal & 2,220 & 17,845 & 0 & 52,977 & 72,677 & 0 & 27,157 & 41,993 & $\overline{0}$ & 214,868 \\
\hline & & & & & & & & & & \\
\hline \multicolumn{11}{|l|}{ Ministry of Education } \\
\hline Education Buildings & 701 & 6,880 & $1,0.12$ & 1,401 & 16,572 & 22,040 & 702 & 3,101 & 11,257 & 63,665 \\
\hline Hostels & 348 & 1,074 & 1,259 & 153 & 1,565 & 26,235 & 0 & 0 & 3,221 & 33,856 \\
\hline Subtotal & 1,049 & 7,954 & 2,271 & 1,554 & 18,137 & 48,275 & 702 & 3,101 & 14,478 & 97,521 \\
\hline \multicolumn{11}{|l|}{ Municipal Dept. of Culture } \\
\hline Theaters & 0 & 2,205 & 155 & 302 & 0 & 0 & 0 & 0 & 227 & 2,889 \\
\hline Art Galleries/Museums & 568 & 470 & 167 & 0 & 0 & 909 & 163 & 132 & 0 & 2,409 \\
\hline Subtotal & 568 & 2,675 & 322 & 302 & 0 & 909 & 163 & 132 & 227 & 5,299 \\
\hline Total & & & & & & & & & & 378,236 \\
\hline
\end{tabular}


Table A.6. Institutional Building Sector Total Investment Requirements

\begin{tabular}{|c|c|c|c|c|c|c|c|c|c|c|}
\hline \multirow{3}{*}{$\begin{array}{l}\text { Institutional Building } \\
\text { Owner and Category }\end{array}$} & \multicolumn{10}{|c|}{ Total Investment by Vintage and Size (\$) } \\
\hline & \multicolumn{3}{|c|}{ Pre-1958 } & \multicolumn{3}{|c|}{$1958-1980$} & \multicolumn{3}{|c|}{ Post-1980 } & \multirow{2}{*}{$\begin{array}{c}\text { Total } \\
\text { Invest- } \\
\text { ment }\end{array}$} \\
\hline & $<3$ Stories & 3-4 Stories & $>4$ Stories & $<3$ Stories & 3-4 Stories & $>4$ Stories & $<3$ Stories & 3-4 Stories & $>4$ Stories & \\
\hline \multicolumn{11}{|l|}{ Municipal Dept. of Health } \\
\hline Hospitals & 498,182 & 375,952 & 99,602 & 80,715 & 398,313 & 909,417 & 67,216 & 58,610 & 987,011 & $3,475,019$ \\
\hline Polyclinics & 201,931 & 81,096 & 10,785 & 39,292 & 297,754 & 62,165 & 16,829 & 250,773 & 595,084 & $1,555,709$ \\
\hline Administration & 176,888 & 22,890 & 28,532 & 81,491 & 40,460 & 74,213 & 21,461 & 29,001 & 98,355 & 573,290 \\
\hline Subtotal & 877,002 & 479,938 & 138,919 & 201,499 & 736,527 & $1,045,795$ & 105,506 & 338,383 & $1,680,449$ & $5,604,018$ \\
\hline & & & & & & & & & & \\
\hline \multicolumn{11}{|l|}{ Municipal Dept. of Ed. } \\
\hline Kindergartens & 319,309 & 9,519 & 0 & $4,062,210$ & 0 & 0 & $2,176,477$ & 495,371 & 0 & $7,062,886$ \\
\hline Schools & 46,183 & $1,918,577$ & 0 & 67,132 & $4,908,904$ & 0 & 67,625 & $2,711,557$ & 0 & $9,719,980$ \\
\hline Subtotal & 365,492 & $1,928,096$ & 0 & $4,129,342$ & $4,908,904$ & 0 & $2,244,102$ & $3,206,929$ & 0 & $16,782,866$ \\
\hline & & & & & & & & & & \\
\hline \multicolumn{11}{|l|}{ Ministry of Education } \\
\hline Education Buildings & 85,028 & 834,330 & 122,763 & 92,431 & $1,093,260$ & $1,468,286$ & 52,997 & 234,266 & 836,910 & $4,820,270$ \\
\hline Hostels & 41,640 & 128,419 & 150,503 & 18,333 & 187,092 & $2,280,142$ & 0 & 0 & 385,031 & $3,191,160$ \\
\hline Subtotal & 126,668 & 962,748 & 273,267 & 110,763 & $1,280,352$ & $3,748,429$ & 52,997 & 234,266 & $1,221,941$ & $8,011,430$ \\
\hline \multicolumn{11}{|l|}{ Municipal Dept. of Culture } \\
\hline \begin{tabular}{|l|} 
Theaters \\
\end{tabular} & 0 & 201,076 & 14,112 & 21,734 & 0 & 0 & 0 & 0 & 18,623 & 255,545 \\
\hline Art Galleries/Museums & 135,971 & 90,480 & 32,112 & 0 & 0 & 96,394 & 23,293 & 18,843 & 0 & 397,093 \\
\hline Subtotal & 135,971 & 291,556 & 46,224 & 21,734 & 0 & 96,394 & 23,293 & 18,843 & 18,623 & 652,638 \\
\hline Total & & & & & & & & & & $31,050,952$ \\
\hline
\end{tabular}


Appendix B

Regulations on Foreign Loans 


\section{Appendix B}

\section{Regulations on Foreign Loans}

This appendix contains a summary of two Decrees (\#s 25-93 and 1002) by the Cabinet of Ministers and the text of Decree \#414. The three Decrees pertain to the issuance of a sovereign guarantee for international loans and the repayment of guaranteed loans. Decree \#414, adopted in May 1997, replaces Decree \#440, adopted in April 1996 and is the most important of the three. Decree \#414 contains three parts and three annexes as follows:

- On Streamlining Attraction and Use of Foreign Credits the Repayment of Which is Guaranteed by the Cabinet of Ministers of Ukraine, Improvement of the System of External Financial Resources Attraction and External State Debt Servicing.

- Regulations on the Order of Preparation and Implementation of Economy Development Projects in Ukraine Supported by International Financial Institutions.

- Regulations on the Order of Attracting Foreign Credits and Providing Guarantees of the Cabinet of Ministers of Ukraine to Secure Obligations of Resident Legal Persons as to Their Repayment.

- Annex No. 1 to the Regulations on the Order of Attracting Foreign Credits and Providing Guarantees of the Cabinet of Ministers of Ukraine to Secure Obligations of Resident Legal Persons as to Their Repayment.

- Annex No. 2 to the Regulations on the Order of Attracting Foreign Credits and Providing Guarantees of the Cabinet of Ministers of Ukraine to Secure Obligations of Resident Legal Persons as to Their Repayment.

- Annex No. 3 to the Regulations on the Order of Attracting Foreign Credits and Providing Guarantees of the Cabinet of Ministers of Ukraine to Secure Obligations of Resident Legal Persons as to Their Repayment.

\section{Sovereign Guarantees for International Loans}

According to the Cabinet of Ministers of Ukraine's Decree "On Sovereign Guarantees for Foreign Loans Given to Ukraine under International Agreements" \#25-93 of 03.17.93 (Cabinet of Ministers of Ukraine 1993), the Cabinet of Ministers of Ukraine acts on behalf of the State as a guarantor for repayment of loans of international financial institutions. 
Loan service is the responsibility of the State Export-Import Bank, but the Cabinet of Ministers can assign that for another financial institution as well.

For financial provision of the guarantees, a special reserve is created in the State Currency Fund of Ukraine. It is also possible to provide for guarantees by a property collateral.

Collateral may be represented by both the borrower's own property and by the property being in the borrower's full economic disposal (in the latter case-by consent of the owner). Collateral may also be the property that will be owned by the borrower by the time the loan is received, if this is allowed by the loan agreement. Physically, a collateral may be represented by buildings under construction fully financed from the budget, as well as by other state property not transferred to other legal persons in full economic disposal or operational management.

\section{Redemption of the State Budget Losses Resulted from Guaranteed Situations with Foreign Loans}

The Cabinet Ministers adopted the Decree "On Procedure of Compensating for the State Budget Losses that Resulted from Occurrence of Events Guaranteed Against in Agreements on Foreign Loans Received by Ukrainian Legal Persons Under Guarantees of the Government of Ukraine" (\#1002 of 12.14.96; Cabinet of Ministers of Ukraine 1996b). This Decree states that the borrower's responsibility to the state budget arises, within the limits of budget expenses that were necessary to repay the borrower's obligations specified by loan agreement between the borrower and the bank acting as an agent of the Government of Ukraine, from the moment of the guarantor's paying specified amounts.

To comply with the above-mentioned Decree, the Ministry of Finance issued an order (\#88 of 04.30.96), which determines procedure of transferring to the state budget amounts taken from Ukrainian legal persons (borrowers) to acquit debts on foreign loans guaranteed by the Government of Ukraine.

Under the mentioned Order, Department of Foreign Debt of the Ministry of Finance collects information from the agent bank (Ukreximbank) regarding Ukrainian legal persons who did not meet schedule of payments, and entailed expenses of the state budget for loan service and repayment. This information is forwarded to branch-specific departments of the Ministry of Finance and to central and regional offices of the State Treasury.

If within a month term the borrower does not redeem the state budget expenses, the State Tax Administration on instruction of a regional office of the State Treasury, recovers from the borrower in an indisputable way the total unpaid amount including fines. The amounts in national currency are transferred to the State Treasury's account with the National Bank, and in foreign currencies - to the State Treasury's account with Ukreximbank. Information on amounts returned to the state budget is 
submitted by the State Tax Administration to the regional office of the State Treasury, and by the latterto the Central State Treasury Office and Department of Foreign Debt of the Ministry of Finance. Based on the information from the Ministry of Finance, Ukreximbank writes off the borrower's debt in the amount returned to the state budget.

\section{Legal Regulation of Institutional Aspects of Preparation and Implementation of IBRD-Supported Projects in Ukraine}

In May 1997, the Cabinet of Ministers of Ukraine issued Decree \#414, which confirmed a regulation about projects supported by the International Bank for Reconstruction and Development (IBRD) in Ukraine (full text of the regulation is given below). 


\section{CABINET OF MINISTERS OF UKRAINE}

\section{REGULATION}

of May 5,1997

No. 414

Kyiv

On Streamlining Attraction and Use of Foreign Credits

the Repayment of Which is Guaranteed by the Cabinet of Ministers of

Ukraine, Improvement of the System of External Financial Resources Attraction and

External State Debt Servicing

With the purpose of streamlining attraction and use of foreign credits the repayment of which is guaranteed by the Cabinet of Ministers of Ukraine, improvement of the system of external financial resources attraction and better external State debt servicing, the Cabinet of Ministers of Ukraine

\section{REGULATES:}

1. To establish that:

decisions on granting to resident legal persons of Ukraine the right to use foreign credits drawn by Ukraine shall be taken at the meeting of the Cabinet of Ministers on the submission from the Currency and Credit Council under the Cabinet of Ministers of Ukraine, and presented in the form of the Regulation of the Cabinet of Ministers of Ukraine;

decisions on appointing agent banks of the Cabinet of Ministers of Ukraine for attracting and servicing of foreign credits the repayment of which is guaranteed by the Cabinet of Ministers of Ukraine shall be taken at the Cabinet of Ministers of Ukraine meeting on the submission from the Currency and Credit Council under the Cabinet of Ministers of Ukraine, and presented in the form of the Regulation of the Cabinet of Ministers of Ukraine;

the Currency and Credit Council under the Cabinet of Ministers of Ukraine shall submit draft decisions on granting guarantees to foreign creditors on securing fulfillment by resident legal persons of their obligations on repayment of foreign credits drawn on the terms of currency self-repayment only after concluding of the agreement between the said legal persons and the Ministry of Finance on the order of compensating expenditures from the state budget that could arise as a result of fulfillment by the Cabinet of Ministers of Ukraine of its guarantee obligations. 
2. To approve the enclosed

Regulations on the Order of Attracting Foreign Credits and Providing Guarantees of the Cabinet of Ministers of Ukraine to Secure Obligations of Resident Legal Persons as to Their Repayment:

Regulations on the Order of Preparation and Implementation of Economy

Development Projects in Ukraine Supported by International Financial Institutions:

Measures for Compensating State Budget Expenditures for Fulfilling Guarantee

Obligations of the Cabinet of Ministers of Ukraine;

Measures for Servicing State External Debt of Ukraine to the Russian Federation and Turkmenistan.

3. To warn the state bodies' officials about their personal responsibility for providing positive conclusions, letters supporting resident legal persons' credit projects the financing of which is effected at the expense of foreign credits whose repayment is guaranteed by the Cabinet of Ministers of Ukraine.

4. To establish that:

in case of providing guarantees of the Cabinet of Ministers of Ukraine to secure fulfillment, by a resident legal person, of obligations as to repayment of foreign credits drawn under conditions of currency self-repayment, the said legal person shall transfer to the Ministry of Finance account from which the servicing of state foreign debt is effected, a payment in the amount of 1 percent of the yearly guarantee sums within the period specified in the internal credit agreement with the agent bank of the Cabinet of Ministers of Ukraine:

requirements to the structure, contents and forms of documents submitted for state expert evaluation and consideration of the Currency and Credit Council of the Cabinet of Ministers of Ukraine, as well as forms of submission by the resident legal person of information on the status and effectiveness of use of the foreign credit whose repayment is guaranteed by the Cabinet of Ministers of Ukraine, shall be approved by the Currency and Credit Council of the Cabinet of Ministers of Ukraine on the submission from the National Agency for Reconstruction and Development, Ministry of Economy, Ministry of Finance and the agent bank.

5. National Agency for Reconstruction and Development shall secure coordination of cooperation between ministries, other central executive power bodies, enterprises, institutions and organizations with international financial institutions, as well as exercising control over preparation and implementation of projects supported by them. 
6. National Agency for Reconstruction and Development, Ministry of Economy, Ministry of Finance in cooperation with other central executive power bodies shall, within one month, draw up and approve:

Order of Competitive Selection of Organizations-Recipients of Credits for Implementation of Investment Projects Supported by the International Financial Institutions:

forms of executive power bodies reporting on the status of preparation and implementation of economy development projects in Ukraine supported by the international financial institutions.

7. Currency and Credit Council under the Cabinet of Ministers of Ukraine shall within one month, on submission from the National Agency for Reconstruction and Development, approve the list and forms of documents needed for consideration and taking decision on expediency of attracting credits from international financial institutions for implementation of the economy development project of Ukraine.

8. National Agency for Reconstruction and Development, Ministry of Economy, Ministry of Finance together with State Property Fund and other central executive power bodies shall, within one month, submit a Draft Act of the President of Ukraine on Authorizing the National Agency for Reconstruction and Development to confirm the Ukraine's approval for implementation of investment projects supported by the European Bank for Reconstruction and Development not requiring state guarantees in accordance with Article 13 of the Agreement on the Establishment of the European Bank for Reconstruction and Development.

9. To introduce amendments and additions, in accordance with the Annex, to the Regulation of the Cabinet of Ministers of Ukraine of August 17, 1995 No. 655 "On Additional Securing of Guarantees and other Obligations of the Government of Ukraine Provided to Foreign Creditors Regarding Repayment of Foreign Currency Credits Attracted by Ukrainian Legal Persons" (Collection of Laws of Ukraine, 1996, No. 1, p. 6, No. 4, p. 131).

10. To declare the Regulation of the Cabinet of Ministers of Ukraine of April 18, 1996 No. 440 "On the Order of Preparation of the Economy Development Projects In Ukraine Supported by the International Bank for Reconstruction and Development" (Collection of Laws of Ukraine, 1996, No. 10, p. 300) null and void.

\section{P. LAZARENKO,}

Prime Minister of Ukraine 
APPROVED

by the Cabinet of Ministers of Ukraine

Regulation of May 5, 1997 No. 414

\section{REGULATIONS}

on the Order of Preparation and Implementation of Economy Development Projects in Ukraine Supported by International Financial Institutions

1. These Regulations define the order of preparation and implementation of Ukrainian economy. development projects supported, in accordance with international treaties of Ukraine, by such international financial institutions as the International Bank for Reconstruction and Development, European Bank for Reconstruction and Development (hereinafter referred to as IFI) with the exception of the International Monetary Fund.

2. The terms used in these Regulations shall have the following meaning: projects shall mean systemic and investment projects of Ukrainian economy development supported by the IFI;

systemic projects shall mean projects aimed at the implementation of economic reform in Ukraine, including State sector reformation, structural and institutional changes in industries and economy sectors, with financial resources provided by IFI for systemic projects to be used exclusively for support of the balance of payments and financing of the State budget deficit, and repaid at the expense of the State budget funds:

investment projects shall mean development projects in individual industries and economy sectors, productions which are financed on the terms of self-repayment and obligatory internal co-financing.

3. Ukraine's cooperation with IFI shall be accomplished in accordance with the statutory documents of those institutions, international treaties of Ukraine, legislation in force, as well as these Regulations with the purpose of attracting external financial resources for implementation of systemic and investment projects.

4. Specific terms and conditions of financial assistance provided by the IFI shall be defined by corresponding international treaties of Ukraine.

5. Ministry of Finance, National Agency for Reconstruction and Development (hereinafter referred to as Agency), Ministry of Economy shall, within two weeks after the State budget is approved, prepare a schedule for receiving external funds for State budget financing, after which the Agency, together with Ministry of Economy and Ministry of Finance shall, within one month, prepare a schedule of concluding international treaties with the IFI. The said documents shall be approved by joint orders. 
6. To prepare and implement the projects, technical and financial assistance may be drawn when needed on the free basis (grants) form the IFI, other international organizations, individual States.

7. Ministry of Economy, together with the Ministry of Finance Agency, other executive power bodies concerned shall, in accordance with established procedure, submit to the Cabinet of Ministers of Ukraine the agreed proposals regarding necessity to prepare the project and substantiation of its conformity to the strategy of economic and social development of Ukraine in the short and long run, and amounts of internal and external financial resources which need to be attracted, with the Agency conducting preliminary negotiations with the IFI and defining the possibility of attracting their financial resources.

8. On instructions from the Vice Prime Minister of Ukraine, the Agency shall begin negotiating the joint development of the project with the IFI.

9. In case the IFI officially supports joint development of the project the Agency in combination with other executive power bodies shall work with the IFI on the issues of organizing project preparation and develop a preliminary plan involving main structural components of the project, financing levels, timetables for project preparation and implementation.

10. Forming of composition of organizations-recipients of the credit for the investment project implementation shall, as a rule, be effected on competitive basis in accordance with procedure established jointly by the Agency, Ministry of Economy and Ministry of Finance.

11. The Agency, together with the Ministry of Finance, Ministry of Economy, other executive power bodies concerned shall submit to the Cabinet of Ministers of Ukraine the draft Cabinet of Ministers of Ukraine decision on:

establishment of the Interagency Coordinating Council (hereinafter referred to as Council) to provide coordination and control over systemic project preparation and implementation. When needed, interagency working groups my be established under the Council:

establishment of the Interagency Working Group (hereinafter referred to as Working Group) for providing coordination and control over investment project preparation and implementation;

designating executive power bodies charged with project preparation and implementation (hereinafter referred to as project performers).

12. The Council (Working Group) shall coordinate and exercise control over cooperation of executive power bodies with the IFI, drawing up necessary documents, analyze implementation of measures for the project preparation and implementation, and prepare proposals on securing their strict implementation, etc. 
To secure project preparation and implementation, the Council (Working Group) shall have the right to attract, in accordance with established procedure, specialists from executive power bodies, research and development institutions, educational establishments, and foreign specialists.

Decisions taken by the Council (Working Group) within its competence shall be binding for ministries, other executive power bodies and organizations taking part in the project preparation.

Head of the Council (Working Group) shall have the right to amend its personal composition.

Head of the Council (Working Group), managers of project performers shall be held personally responsible for development and execution of measures aimed at project preparation and implementation.

Action plans for the project preparation shall be approved, and project implementation plans endorsed by protocol decisions of the Council (Working Group) on submission from the Agency in combination with project performers and executive power bodies concerned.

13. Project performers, together with executive power bodies concerned, shall secure:

fulfillment of the action plan for the project preparation, including development of the Economic Policy Memorandum, project documentation package and relevant project agreements, drafts credit, guarantee (Ukrainian and English language versions) and subsidiary loan agreements, agreements on compensating for the State budget losses which could arise as a result of the guarantee obligations fulfillment, agent agreements, other documents submitted for consideration to the Currency and Credit Council under the Cabinet of Ministers of Ukraine, etc.;

implementation of measures which precede IFI decisions on the financial assistance provision.

14. The list and forms of documents submitted for consideration to the Currency and Credit Council under the Cabinet of Ministers of Ukraine shall be approved, on submission from the Agency, by the Currency and Credit Council under the Cabinet of Ministers of Ukraine.

15. On instructions from the Vice Prime Minister of Ukraine and on submission from the Agency, executive power bodies and organizations conduct expert evaluation of the documents package on the project.

16. Upon receiving a positive expert conclusion the Agency shall submit the agreed documents package on the project to be considered by the Currency and Credit Council under the Cabinet of Ministers of Ukraine with the purpose of taking a decision on expediency of attracting IFI financial resources for implementation of the project. 
17. In case the Currency and Credit Council under the Cabinet of Ministers of Ukraine takes a decision on inexpediency of attracting IFI financial resources for project implementation, the project development may be suspended on the instructions from the Vice Prime Minister of Ukraine upon submission from the Currency and Credit Council under the Cabinet of Ministers of Ukraine.

18. In case the Currency and Credit Council under the Cabinet of Ministers of Ukraine takes a positive decision, the Agency shall submit to the Cabinet of Ministers of Ukraine, in accordance with established procedure, the proposals for negotiations, and the package of agreed documents endorsed by the Currency and Credit Council under the Cabinet of Ministers of Ukraine, as well as negotiations guidelines, and designate the Ukrainian delegation composition which should include representatives of project performers, the Agency, Ministry of Finance, Ministry of Economy, other central executive power bodies concerned, employees of the Cabinet of Ministers of Ukraine Office, as well as commissions members of the Supreme Rada (if agreed).

19. Negotiations results shall be recorded in the minutes to be signed by persons authorized by the parties.

20. Upon completion of negotiations the Agency, within 10 days, on submission from the delegation head shall submit to the Cabinet of Ministers of Ukraine a report on negotiations results, signed minutes of negotiations and other materials. The documents submitted shall be sent to relevant executive power bodies to be agreed upon, and within 10 days shall be submitted by the Agency to the Cabinet of Ministers of Ukraine together with the draft letter affirming the negotiations results by the Ukrainian side which shall be sent to the IFI after signing. Moreover, the corresponding agreements shall be unconditionally signed between the Ministry of Finance and credit receiving organizations for the investment project to be implemented; these should specify terms and conditions of their coming into effect at the moment when relevant agreements between Ukraine and the IFI take effect.

21. On receiving of an official IFI decision as to the project financing the Agency shall, in conjunction with the MFA and other executive power bodies concerned and in accordance with established procedure, submit to the Cabinet of Ministers of Ukraine draft decisions regarding the approval of the corresponding draft international treaty with the IFI, and authorization of its signing.

22. On signing the treaty, in case it is required for the international treaty between Ukraine and the IFI to take effect, the Agency in combination with executive power bodies shall prepare and send to the MFA a documents package needed for their further submission to be ratified by the Supreme Rada of Ukraine in accordance with established procedure. The time framework shall be defined by the Agency taking into account the schedule of external revenues for budget deficit financing, and terms of the international agreement.

23. Ministry of Justice shall secure the preparation of a legal conclusion as to taking effect by the international treaty between Ukraine and the IFI and, together with the Agency, send it to the IFI. 
24. The Agency shall inform the Cabinet of Ministers of Ukraine about the moment when the international agreement of Ukraine will come into effect for the IFI.

25. Within one month after the international treaty of Ukraine takes effect the Agency shall, together with the Ministry of Finance, Ministry of Economy, project performers and other executive power bodies, submit to the Cabinet of Ministers of Ukraine the draft Government decision on approval of the action plan for project implementation endorsed by the Council (Working Group).

26. In accordance with the international treaty, or in order to implement measures preceding the IFI decision on granting international assistance a Project Management Unit shall be formed for day-today management of the project implementation whose Head should be the member of the Council of the Working Group.

27. The Project Management Unit shall effect:

development of project implementation schedule:

preparation and holding of procurements by organizing international competitive bids (tenders):

day-to-day management of the project implementation;

analysis of the status of actual project implementation and preparation of proposals on taking measures aimed at project implementation;

control of actual expenditures for the project and financial conditions of borrowing organizations;

evaluation of the project's economic efficiency taking into account the expenditures, period of recoupment, timely repayment of credits;

solving current problems;

organization of audits;

preparing periodic accounts and final report on the project.

28. The Ministry of Finance shall keep the Registry of Ukraine's international treaties with the IFI and, together with project performers, exercise control over purpose-oriented use of financial funds, fulfillment by the borrower of the obligations regarding the credit repayment.

Ministry of Economy shall, together with project performers, exercise control over implementing measures on the economy reformation envisaged by the terms of the international treaty with the IFI. 
Project performers shall exercise control over project agreements implementation.

The Agency shall generalize the results of control over the project preparation and implementation status.

29. Ministry of Finance, Ministry of Economy, project performers shall, on a quarterly basis, by the $10^{\text {th }}$ day of the month following the period accounted for, submit to the Agency the information on the project preparation and implementation status. The forms of the said information submission shall be approved jointly by the Agency, Ministry of Economy, and Ministry of Finance.

30. The Agency, together with Councils and Working Groups shall, on a quarterly basis, by the $30^{\text {th }}$ day of the month following the period accounted for, submit the generalized information on the projects preparation and implementation status and the action plan for securing their timely implementation to the Cabinet of Ministers of Ukraine.

31. The Agency, at least once a year, shall submit the issues of Ukraine's cooperation with the IFI to the Cabinet of Ministers of Ukraine for consideration.

32. On submission from the Agency, the Cabinet of Ministers of Ukraine shall, together with the Council and the Working Group, approve the final report on the project implementation. The Agency shall inform the IFI about the results of project implementation in Ukraine.

33. At the IFI request the Agency shall provide, in keeping with legislation requirements, the current information regarding project preparation or implementation. 


\title{
APPROVED
}

by the Regulation of the Cabinet of Ministers

of Ukraine of May 5, 197 No. 414

\author{
REGULATIONS \\ on the Order of Attracting Foreign Credits and Providing Guarantees of the \\ Cabinet of Ministers of Ukraine to Secure Obligations of Resident Legal Persons as \\ to Their Repayment \\ General part
}

1. These Regulations shall establish the order of attracting foreign credits for financing the projects in priority areas of Ukraine's economy development (hereinafter referred to as foreign credits) and providing payment guarantees or other obligations of resident legal persons for foreign credits attracted in accordance with the legislation.

2. Guarantees of the Cabinet of Ministers of Ukraine shall be provided irrespective of property forms of resident legal persons.

3. Guarantees of the Cabinet of Ministers of Ukraine shall be provided for securing obligations of resident legal persons regarding repayment of foreign credits attracted in the form of:

credits (credit lines) extended to Ukraine by foreign States, international financial institutions and foreign banks in accordance with international treaties of Ukraine concluded in accordance with legislation;

interbank credit lines being drawn according to the decision of the Government of Ukraine by the State Export-Import Bank (hereinafter referred to as Ukresimbank) or other banks-agents of the Cabinet of Ministers of Ukraine (hereinafter agent banks) from foreign banks and international financial institutions in accordance with legislation;

credits in foreign exchange extended to legal persons residents by international financial institutions, foreign banks, financial and credit and other institutions, firms and organizations in accordance with international treaties of Ukraine concluded according to legislation, under condition of servicing of said credits by agent banks. 
4. The provision of guarantees by the Cabinet of Ministers of Ukraine shall be preceded by State expert evaluation of projects for implementation of which foreign credits are drawn.

State expert evaluation shall be effected by the National Agency for Reconstruction and Development, Ministry of Economy, Ministry of Finance, Ministry of Foreign Economic Relations and Trade, other State bodies, agent banks.

5. Agent functions on drawing and servicing foreign credits the repayment of which is guaranteed by the Cabinet of Ministers of Ukraine shall be performed by the agent banks designated by the Cabinet of Ministers of Ukraine, with which State bodies authorized by the Cabinet of Ministers of Ukraine shall conclude corresponding agent agreements coordinating them with the Ministry of Finance.

The Order of Considering Proposals on Extending to Ukraine of Foreign Credits Within the Framework of International Treaties

6. Proposals regarding extension of credits to Ukraine which have been officially filed with foreign missions of Ukraine, ministries, other central executive power bodies directly by official foreign institutions and foreign banks, as well as previous arrangements reached as a result of negotiating the provision of credits, shall be sent to the Cabinet of Ministers of Ukraine without fail.

7. The said proposals shall, with the purpose of defining directions of the credit use, preliminary appraisal of its currency and financial terms and possibility of undertaking obligations by the Cabinet of Minister of Ukraine regarding repayment of the credit taking into account the approved limit of foreign debt for the current year, on instructions from the Prime Minister or Vice Prime Ministers of Ukraine, by considered by the National Agency for Reconstruction and Development, Ministry of Economy, Ministry of Finance, agent bank and, in case of need, with bringing in Security Service of Ukraine and other State bodies representatives.

8. After considering the proposals regarding the provision of a foreign credit to Ukraine the National Agency for Reconstruction and Development shall submit conclusions agreed upon with the Ministry of Economy, Ministry of Finance, agent bank and, in case of need, with other executive power bodies regarding the expediency of further work with the said proposals to be considered by the Currency and Credit Council under the Cabinet of Ministers of Ukraine.

9. The Currency and Credit Council of the Cabinet of Ministers of Ukraine shall consider the conclusions submitted and, in case the positive decision is take, shall charge the National Agency for Reconstruction and Development (with participation of the Ministry of Foreign Affair, Ministry of Economy, Ministry of Finance, agent bank) with preparing draft Statements of the Cabinet of Minister of Ukraine, international treaties, protocols, letters of exchange or other documents regarding the extension of foreign credit to Ukraine; Ministry of Justice shall be charged with legal expert evaluation of draft international agreements. 
10. National Agency for Reconstruction and Development, together with other State bodies drawing up draft international treaties and other documents for attracting the foreign credit, shall inform the Currency and Credit Council under the Cabinet of Ministers of Ukraine of the preparation status of the documents.

Drawing up draft international treaties and interbank credit agreements, on the basis of international arrangements, as well as other documents regarding extension of the foreign credit to Ukraine shall be performed in accordance with the legislation on the general terms of extension, use and repayment of credits defined in such arrangements.

11. National Agency for Reconstruction and Development of Ukraine shall submit the finalized draft international treaties, protocols, statements and other documents on extending foreign credit to Ukraine to the Currency and Credit Council under the Cabinet of Ministers of Ukraine for approval.

12. After final approval of the documents on extending foreign credit to Ukraine submitted in accordance with para. 11 of this Regulation, the Currency and Credit Council under the Cabinet of Ministers of Ukraine shall:

consider the issue of delegating authority to officials for signing the said documents. The decision shall be duly registered in the Council meeting minutes;

submit to the Cabinet of Ministers of Ukraine draft decision regarding conclusion of international treaties and authorization of officials to sign, on behalf of the Cabinet of Ministers of Ukraine or Ukraine, international treaties or other documents on drawing a foreign credit.

13. International treaties and other documents on drawing the foreign credit signed by authorized officials shall be sent to the Ministry of Foreign Affairs and within three days copies of same shall be submitted to the Cabinet of Ministers of Ukraine, National Agency for Reconstruction and Development, Ministry of Economy, Ministry of Finance, National Bank, and the agent bank.

14. Original texts of international treaties or other documents on extending foreign credit to Ukraine, as well as amendments and additions to them after their signing and taking effect, shall be registered and kept at the Ministry of Foreign Affairs. Certified copies of the said documents within one week after their coming into effect shall be sent to the Ministry of Finance to be registered, as well as to the Cabinet of Ministers of Ukraine, National Agency for Reconstruction and Development, Ministry of Economy, National Bank, and the agent bank.

Original texts of international treaties or other documents concluded by agent banks, as well as amendments and additions to them, on instructions from the Prime Minister of Ukraine or Vice Prime Ministers of Ukraine shall be kept at these banks. Certified copies of the said documents shall 
be sent to the Cabinet of Ministers of Ukraine, National Agency for Reconstruction and Development, Ministry of Economy, and for registration to the Ministry of Finance, National Bank, and the Ministry of Foreign Affairs.

15. In case of need, the Currency and Credit Council under the Cabinet of Minister of Ukraine shall, on submission from the central executive power body depending on the sector for the development of which the credit is drawn, upon agreement with the National Agency for Reconstruction and Development and Ministry of Economy, designate a legal person - chief performer of the agent of the Cabinet of Ministers of Ukraine to implement this credit.

16. The Ministry of Justice within one month shall, if not otherwise stipulated by the international treaty, prepare and send to the foreign partner who concluded the international agreement, the legal conclusion and/or other material prepared by it required for taking effect by the credit agreement and, in cooperation with the Ministry of Foreign Affairs, and after agreeing it with the agent bank, shall submit to the Cabinet of Ministers of Ukraine proposals regarding appointing an agent to the Cabinet of Ministers of Ukraine proposals regarding appointing an agent of the Cabinet of Ministers of Ukraine for dealing with possible judicial procedures and defending the interests of Borrower and Guarantor during the proceedings.

17. National Agency for Reconstruction and Development shall prepare and present to the Ministry of Foreign Affairs necessary materials for the concluded international agreements on extending foreign credits to Ukraine to be submitted for ratification by the Supreme Rada of Ukraine.

Order of Considering Proposals on Attracting by Resident Legal Persons of Foreign Credits the Repayment of Which is Guaranteed by the Cabinet of Ministers of Ukraine

18. Foreign missions of Ukraine, other State bodies, resident legal persons who have received a proposal to extend an international credit providing for receiving by the foreign creditor of guarantees of the Cabinet of Ministers of Ukraine shall send the said proposals to the Cabinet of Ministers of Ukraine.

19. Should the said proposal come from a foreign bank, financial and credit institutions and firms which have never before extended credits to Ukraine or its resident legal persons shall provide, together with the proposal to extend a creclit, the document legalized in accordance with the established procedure and the information listed in Annex 1 to these Regulations.

Documents and information not conforming with those set in Annex 1 shall no be taken for considerations. 
20. On instruction from the Prime Minister of Ukraine of Vice Prime Ministers of Ukraine, consideration of proposals mentioned in para. 18 shall be implemented by relevant State bodies in accordance with Section II of the Regulation.

Order of Preliminary Consideration of Applications of Resident Legal Persons for Receiving Guarantees of the Cabinet of Ministers of Ukraine Regarding Foreign Credits the Repayment of Which is Envisaged to Be Effected On Currency Self-Repayment Terms

21. Resident legal persons who intend to receive guarantees of the Cabinet of Ministers of Ukraine to secure obligations regarding repayment of credits drawn in accordance with these Regulations for financing projects in Ukraine, shall submit to the National Agency for Reconstruction and Development an application letter for receiving the said guarantees, supportive conclusion from the central executive power body according to the economy sector, and conclusion on technical and technological expert evaluation of the project, its feasibility study (business plan), as well as documents confirming the possibility of repaying the credit at the expense of economic activity results and concluding a contract of pledge or surety.

Applications of resident legal persons who have already received the foreign credit under the guarantee of the Cabinet of Ministers of Ukraine shall not be considered till the full repayment of the credit received before.

Resident legal persons can turn: to the National Agency for Reconstruction and Development. Ministry of Economy and Ministry of Finance for clarifications on priority directions of foreign credits use, requirements to price expert evaluations, procedural conditions of the order of providing guarantees of the Cabinet of Ministers of Ukraine, established requirements to drawing up of necessary documents; to the Ministry of Foreign Economic Relations and Trade, on the issues of international bid (tenders) organization, pricing and legal evaluation, import and export contracts; to agent bank, on the issues of financial conditions of foreign credit lines drawn by Ukraine under the guarantees of the Cabinet of Ministers of Ukraine, order of drawing up internal credit agreements, contracts of pledge and/or surety and schemes for repayment of foreign credits drawn; to the State Property Fund and Ministry of Finance, on the issues of appraising the value of the object of pledge.

22. The documents submitted to the National Agency for Reconstruction and Development by resident legal persons for receiving guarantees of the Cabinet of Ministers of Ukraine shall, within ten days, be considered to appraise the possibility of project recoupment and prospects of concluding the contract of pledge and/or surety, and shall be submitted for preliminary consideration to the Currency and Credit Council under the Cabinet of Ministers of Ukraine.

23. The Currency and Credit Council under the Cabinet of Ministers of Ukraine shall take a preliminary decision on expediency of further work with the documents submitted and possibility to provide guarantees of the Cabinet of Ministers of Ukraine. 
In case the Currency and Credit Council under the Cabinet of Ministers of Ukraine decides it is impossible to provide guarantees of the Cabinet of Ministers of Ukraine, an extract from the Minutes of its meeting where the relevant decision was taken shall be sent to the resident legal person.

The originals of the documents submitted by the resident legal person to be considered by the Currency and Credit Council under the Cabinet of Ministers of Ukraine shall be enclosed to the Minutes of the Council meeting and kept in accordance with established procedure.

Order of Final Consideration of Applications of Resident Legal Persons for Receiving Guarantees of the Cabinet of Ministers of Ukraine Regarding Foreign Credits the Repayment of Which Is Envisaged to Be Effected on the Terms of Currency Self-Repayment

24. In case of taking a positive preliminary decision regarding the possibility of providing guarantees of the Cabinet of Ministers of Ukraine, Currency and Credit Council under the Cabinet of Ministers of Ukraine shall instruct:

the National Agency for Reconstruction and Development, to generalize proposals, conclusions of ministries and other State bodies and, on getting the results of the analysis and expert evaluation of the project, to prepare a generalized proposal and conclusion on expediency of providing guarantees of the Cabinet of Ministers of Ukraine;

Ministry of Economy, to establish conformity of the project to priority directions of foreign credits use and Ukraine's economic development, as well as conduct general feasibility study of the project;

State Property Fund, to consider conformity of the project to State policy with regard to State property (in case it is pledged);

Ministry of Finance, to conduct analysis of financial condition of the borrower, existing indebtedness to the budget and liquid assets;

organizations defined by the Currency and Credit Council under the Cabinet of Ministers of Ukraine, to conduct expert evaluations of prices of import and export contracts and, in case of need, expert evaluation of projects' economic effectiveness;

Ministry of Foreign Economic Relations and Trade, to conduct legal examination of export and import contracts, as well as examination of the results of international bid (tenders) for import procurements;

agent bank, to conduct analysis of resident legal person's ability to pay, currency self-repayment of the project and its conformity to general terms of credits drawn for financing, to prepare draft contracts of pledge and/or surety. 
In case of need the Currency and Credit Council under the Cabinet of Ministers of Ukraine can bring in other State bodies to conduct State expert evaluation.

25. To effect a final expert evaluation of the project, the resident legal person shall submit a full package of documents listed in Annex 2 to these Regulations to the National Agency for Reconstruction and Development, Ministry of Economy, Ministry of Finance, agent bank and, when needed, to other State bodies defined by the Currency and Credit Council under the Cabinet of Ministers of Ukraine.

The documents not conforming to the requirements of these Regulations are not to be considered.

The consideration of documents prepared in accordance with requirements of these Regulations and those submitted by the resident legal persons shall be effected by the said bodies and organizations within the period not exceeding 20 days.

26. The bodies, organizations conducting State expert examination of the project shall have the right to send requests to the resident legal person for additional information needed for preparing conclusions regarding provision of guarantees of the Cabinet of Ministers of Ukraine, including confirmation of materials and documents submitted by it by independent auditor firms and other organizations designated by the Currency and Credit Council under the Cabinet of Ministers of Ukraine. In case the State property is pledged, preparation of conclusions and proposals regarding the provision of guarantees of the Cabinet of Ministers of Ukraine shall be effected by the State Property Fund with brining in independent experts.

27. A list of organizations whose conclusions (expert evaluations) the Currency and Credit Council under the Cabinet of Ministers of Ukraine takes into consideration while solving the issue of expediency of providing guarantees of the Cabinet of Ministers of Ukraine, shall be defined by it on submission from the National Agency for Reconstruction and Development, Ministry of Economy, Ministry of Finance, and agent bank.

All costs related to conducting expert evaluations shall be borne by the resident legal person.

28. The National Agency for Reconstruction and Development shall generalize and submit to the Cabinet of Ministers of Ukraine the results of the project's expert evaluation, together with copies of documents submitted by the resident legal person and conclusions of the Ministry of Economy, Ministry of Finance, other State bodies, agent bank, organizations in case they are engaged in conducting expert evaluations of the projects.

29. Documents submitted to the Cabinet of Ministers of Ukraine by the National Agency for Reconstruction and Development shall be processed by sectoral departments or divisions of the Cabinet of Ministers of Ukraine within 10 days, and submitted for consideration to the Vice Prime Minister of Ukraine in accordance with division of functional authority and thereafter, with his conclusion as to necessity of implementation of the said project, shall be sent to the Foreign 
Economic Relations Division of the Cabinet of Ministers of Ukraine (hereinafter referred to as Working Body of the Currency and Credit Council under the Cabinet of Ministers of Ukraine) not later than 7 days before it meets.

30. The Working Body of the Currency and Credit Council under the Cabinet of Ministers of Ukraine shall consider the submitted documents, prepare proposals for consideration of the issue at its meeting, and send agenda and the materials to the Council members before the next meeting two days in advance, as well as inform the resident legal person of the date that issue will be considered.

31. The Currency and Credit Council under the Cabinet of Ministers of Ukraine shall consider the documents processed in accordance with this Section and take the decision on expediency of providing the guarantee of the Cabinet of Ministers of Ukraine.

In the Council meeting minutes, the number and signature date of the contract for financing of which the foreign credit is drawn shall be noted, as well as full name of the resident legal person who applied for the guarantees of the Cabinet of Ministers of Ukraine, and purposes to which the said credit is directed, sources of its repayment.

32. In case the Currency and Credit Council under the Cabinet of Ministers of Ukraine takes a positive decision on the expediency of providing the guarantees of the Cabinet of Ministers of Ukraine, the resident legal persons shall conclude:

internal credit agreements, contracts of pledge with the agent bank (in cases specified in the legislation, the agent bank enters into contracts of pledge and/or surety with the third person (property warrantor)) taking into account that the share of owned property in a contract of pledge for legal persons of non-state forms of ownership shall amount to not less than 20 percent of the overall sum of such contract, and the subject matter of these contracts cannot be confined just to the claim rights:

binding agreements with central executive power bodies according to the economy sector: with the National Agency for Reconstruction and Development, Ministry of Economy and Ministry of Finance regarding the provision of necessary information on the effectiveness of the credit costs use. The form of providing such information shall be specified in the agreement.

Appraisal of value of the property which constitutes the object of pledge shall be effected by the State Property Fund. The value of property rights or securities, financial solvency of the warrantor shall be appraised by the Ministry of Finance. This appraisal shall be done in Ukrainian currency converted into foreign exchange at the National Bank exchange rate at the day of conversion. In case the resident legal person is unable to live up to its commitments regarding the foreign credit and the guarantees of the Cabinet of Ministers of Ukraine come into force, the agent bank with consent from 
the Cabinet of Ministers of Ukraine and in accordance with the legislation shall apply for collection of the property pledged for compensating the guarantee amount and other costs related to repayment of the credit.

The agent bank shall send copies of the contract of pledge with the resident legal person and/or surety with the third persons (property warrantors) to the Ministry of Finance.

33. The agent bank shall conclude internal credit agreements with borrowers provided that they. undertake to open, at this bank only, one currency account by each currency code to which all proceeds in freely convertible currency shall be deposited till full repayment of the foreign credit the repayment of which is guaranteed by the Cabinet of Ministers of Ukraine, payment of interest and commission fees.

Should the foreign exchange funds obtained by means of national currency of Ukraine conversion be directed at repayment of the credit, the resident legal person shall undertake to open at the agent bank one settlement account to which all proceeds in Ukrainian currency should be deposited till full repayment of the credit, payment of interest and commission fees.

In individual cases, by the decision of the Currency and Credit Council under the Cabinet of Ministers of Ukraine, the resident legal person may open a settlement account at another bank servicing it under condition of concluding of an agreement between that bank and the agent bank where there is specified the mechanism for repayment of the foreign credit whose repayment is guaranteed by the Cabinet of Ministers of Ukraine, taking into account interest for the credit, other commission fees and expenditures for the credit.

34. The borrower shall compensate to the agent bank all costs related to the drawing up of contracts of pledge and/or surety, servicing and repayment of the credit, as well as pay commission fees in the amount specified in the internal credit agreement.

35. Drafting of the Cabinet of Ministers of Ukraine on providing individual guarantees of the Cabinet of Ministers of Ukraine for securing of fulfillment by the resident legal persons of obligations regarding foreign credits repayment shall be effected by relevant Sate bodies, and their processing effected by the Working Body of the Currency and Credit Council under the Cabinet of Ministers of Ukraine after the agent bank confirms fulfillment by the borrower of all necessary conditions, and notary certification of the contract of pledge or concluding the contract of surety.

Provision of individual guarantees of the Cabinet of Ministers of Ukraine for securing fulfillment by the resident legal person of obligations regarding repayment of foreign credits shall be effected by relevant State bodies and the Working Body of the Currency and Credit Council under the Cabinet of Ministers of Ukraine on submission from the agent bank after adopting the said Regulation of the Cabinet of Ministers of Ukraine. 
Individual guarantees of the Cabinet of Ministers of Ukraine in favor of foreign creditors shall be provided only when their preparation is envisaged by credit or other agreements between the agent bank and foreign banks. In case of Cabinet of Ministers provides general guarantees for the entire sum of the foreign credit, individual guarantees of the Cabinet of Ministers of Ukraine for securing the fulfillment by the resident legal person of its obligations shall not be provided. Decisions on expediency of providing guarantees of the Cabinet of Ministers of Ukraine for such credits shall be taken in the form of an entry in the minutes of the meeting of the Currency and Credit Council under the Cabinet of Ministers of Ukraine, and a corresponding agreement shall be concluded between the Ministry of Finance and the agent bank. After the Cabinet of Ministers takes the corresponding decision on providing guarantees of the Cabinet of Ministers of Ukraine, the guarantee provided by the Cabinet of Ministers of Ukraine for the entire sum of the foreign credit shall be extended to the sum obligated by the resident legal person under the specific credit.

36. Guarantees of the Cabinet of Ministers of Ukraine for securing the fulfillment by the resident legal person of its obligations taken in accordance with requirements of these Regulations, shall be registered by the Cabinet of Ministers of Ukraine and subject to obligatory registration by the Ministry of Finance in the State Guarantees Register.

The original texts of the Cabinet of Ministers of Ukraine guarantees shall, by special mail, be sent for their further transferring to foreign creditors, and their certified copies shall be sent to the Ministry of Finance for registration.

Should an external credit agreement be concluded with the borrower directly, a certified copy of the guarantee shall also be sent to this borrower.

Guarantees provided by the Cabinet of Ministers of Ukraine under foreign credits which do not envisage individual guarantees, shall be entered by the Ministry of Finance to the State Guarantees Register based on the relevant decision of the Cabinet of Ministers regarding the provision of this guarantee.

37. On receiving of the original guarantees from the Cabinet of Ministers of Ukraine, the agent bank shall conclude an individual credit agreement with the foreign creditor and send him other documents if needed.

Should drawing up of individual credit agreements with foreign creditors not be envisaged, as specified in credit and other agreements, the agent bank should open the financing immediately after concluding of an individual credit or other agreement with the resident legal person.

38. Guarantees of the Cabinet of Ministers of Ukraine extended for securing of fulfillment by the resident legal person of obligations regarding repayment of foreign credits for projects whose financing has not been effected by the foreign creditor within one calendar year after the resident legal person and agent bank take all necessary steps, shall be subject to obligatory reconsideration by 
the Currency and Credit Council under the Cabinet of Ministers of Ukraine for exploring the possibilities of the resident legal person with regard to implementation of the project and confirmation by the Cabinet of Ministers of Ukraine.

Should the foreign creditor officially refuse to open the project financing, the agent bank shall inform the resident legal person of it and submit proposals as to canceling the guarantees to the Currency and Credit Council under the Cabinet of Ministers of Ukraine.

Decisions on expediency of canceling the Cabinet of Ministers of Ukraine guarantees shall be taken by the Currency and Credit Council under the Cabinet of Ministers of Ukraine. The decision on canceling the guarantees of the Cabinet of Ministers of Ukraine shall be taken by the Cabinet of Ministers of Ukraine.

After the Cabinet of Ministers of Ukraine takes the decision on canceling its guarantees, the Ministry of Finance shall introduce corresponding amendments to the State Guarantees Register.

Order of Providing Guarantees or other Obligations of the Cabinet of Ministers of Ukraine for Securing Implementation by the Resident Legal Person of Obligations Regarding Repayment of Foreign Credits the Repayment of Which Is Envisaged to Be Effected by Attracting Funds from the State Budget

40. Consideration of applications of the resident legal persons for the use of budget funds for their repayment shall be held only in case when the funds for such needs are envisaged in the State budget.

41. Resident legal persons having intention to obtain foreign credits the repayment of which is guaranteed by the Cabinet of Ministers and envisaged to be effected at the State budget costs, shall submit to the Ministry of Finance an application letter with expert conclusion of the central executive power body according to the economy sector, and documents listed in Annex No. 3 to these Regulations. In case of positive conclusion of the Ministry of Finance regarding availability of necessary funds in the State budget or possibility that such funds might be envisaged, the document package shall be submitted to the Cabinet of Ministers of Ukraine.

42. Documents filed with the Cabinet of Ministers of Ukraine for receiving guarantees of the Cabinet of Ministers of Ukraine on foreign credits the repayment of which is envisaged to be effected at the expense of State budget funds, shall be considered by sectoral departments or divisions of the Cabinet of Ministers of Ukraine and, with their conclusions, submitted for consideration to the Vice Prime Ministers of Ukraine according to their functional authority.

In case the corresponding Vice Prime Minister takes a decision to support the implementation by the resident legal person of the submitted project where the foreign credit will be used the repayment of 
which is envisaged to be effected at the expense of State budget funds, the documents should be submitted to the Working Body of the Currency and Credit Council under the Cabinet of Ministers of Ukraine not later than 7 days before it meets.

43. The Working Body of the Currency and Credit Council under the Cabinet of Ministers of Ukraine shall consider the submitted documents and prepare proposals for considering the issue at its meeting, as well as inform the resident legal person of the date when the issue is to be considered.

44. The Currency and Credit Council under the Cabinet of Ministers of Ukraine shall take a preliminary decision on the possibility, under condition of positive conclusion of State experts, of providing corresponding guarantees of the Cabinet of Ministers of Ukraine regarding the foreign credit to be drawn.

45. Consideration of the resident legal person's documents for attracting the foreign credit, taking the final decision on providing, drawing up and cancellation of the Cabinet of Ministers of Ukraine guarantees and individual credit agreements shall be effected according to the procedure and within periods specified in sections 25 through 39 of these Regulations taking into account peculiarities of implementing projects with the use of budget funds.

46. Provision of individual guarantees of the Cabinet of Ministers of Ukraine for securing the implementation by the resident legal person of obligations regarding repayment of foreign credits shall be effected by relevant State bodies and the Working Body of the Currency and Credit Council under the Cabinet of Ministers of Ukraine on submission from the agent bank after concluding individual credit agreement between the Ministry of Finance and the resident legal person where the mechanism for budget expenditures compensation for servicing the foreign credit and other necessary conditions are specified.

47. At the time of taking of the decision on expediency of providing guarantees of the Cabinet of Ministers for securing of fulfillment by the resident legal person of obligations as to the foreign debts repayment, the Currency and Credit Council under the Cabinet of Ministers of Ukraine shall take a decision on expediency of providing guarantees of the Cabinet of Ministers in favor of the agent bank. The decision on providing guarantees of the Cabinet of Ministers of Ukraine in favor of the agent bank shall be taken by the Cabinet of Ministers of Ukraine. The said guarantee in favor of the agent bank shall be provided in the form of an agreement between the Ministry of Finance (acting within the authority delegated by the Cabinet of Ministers of Ukraine) and the agent bank. In particular, the agreement shall define the mechanism and volumes of reserving the costs needed for servicing the credit.

Responsibility of the Resident Legal Person Who Received the Cabinet of Ministers of Ukraine Guarantees for Securing the Implementation of Obligations Regarding the

Foreign Credits Repayment 
48. The resident legal person shall be entirely liable for trustworthiness of the information contained in documents submitted to bodies (organizations) conducting State Expert evaluations for receiving guarantees of the Cabinet of Ministers of Ukraine in accordance with these Regulations.

In case the resident legal person provides untrue information regarding the project or its activity, the project is rejected at any state of its procedural consideration. Costs paid by the resident legal person for conducting of the expert evaluation shall not be reimbursed.

49: The resident legal person who has received guarantees of the Cabinet of Ministers of Ukraine for securing the fulfillment of obligations regarding the repayment of foreign credits shall bear, in accordance with the legislation of Ukraine, full responsibility arising from the internal credit and other agreements signed by it with the agent bank, as well as agreements with the Ministry of Finance on the order of compensating State budget expenditures which could arise as a result of fulfillment by the Cabinet of Ministers of Ukraine of its guarantee obligations, and as to securing guarantees of the Cabinet of Ministers of Ukraine for fulfillment of other obligations taken by it.

The resident legal person who has received the Cabinet of Ministers of Ukraine guarantees for securing obligations regarding the repayment of foreign credits shall be held responsible for complete and timely repayment of the credit, interest on it, as well as payment of commission fees.

In case of non-compliance of the resident legal person or its warrantor with the requirements of these Regulations and commitments, the collection of fees on property pledge shall be applied, or a suit to Arbitration court filed in accordance with the legislation.

\section{Final provisions}

50. Control over purpose-oriented and effective use and timely repayment of foreign credits shall be exercised by central executive power bodies according to the economy sector, sectoral departments or divisions of the Cabinet of Ministers of Ukraine, Ministry of Finance, Ministry of Economy, National Agency of Reconstruction and Development, and agent bank. With it all, personal responsibility shall be borne by high officials of corresponding central executive power bodies in the relevant economy sector, and by managers of legal persons residents under whose obligations the guarantees of the Cabinet of Ministers of Ukraine have been provided.

51. The Ministry of Finance shall exercise control over the purpose-oriented use by the resident legal person of obligations on the credit repayment; central executive power bodies in the sector, Ministry of Economy, National Agency for Reconstruction and Development shall supervise the purposeoriented use of credit costs and fulfillment of the resident legal person's payment obligations, including brining in auditor firms. 
52. Ministry of Finance, Ministry of Economy and the National Agency for Reconstruction and Development shall submit, once in six months, the corresponding information for consideration of the Currency and Credit Council under the Cabinet of Ministers of Ukraine; the agent bank shall submit it for each meeting of the Currency and Credit Council under the Cabinet of Ministers of Ukraine and, in case an urgent decision is needed, to the Cabinet of Ministers of Ukraine in accordance with working procedures. 
Annex No. 1

to the Regulations on the Order of Attracting Foreign

Credits and Providing Guarantees of the Cabinet of

Ministers of Ukraine to Secure Obligations of Resident

Legal Persons as to Their Repayment

LIST

of Documents and Information Needed for Considering of

Applications for Attracting Foreign Credits

Official information on the creditor

Full name.

Address.

Telephone, fax and telex numbers.

Place of registration and the body which accomplished it. Telephone, fax and telex numbers of the body which affected the registration.

Names of managers (Chief executive officers) and their phone numbers.

Name of the bank serving to the creditor. Its address, telephone, fax and telex numbers.

Information on major shareholders or owners of the creditor.

List of the creditor's principal activity directions.

Extract from Unified Registry of Statistical Units.

\section{Documents}

Extract from trade or other register of the country where the creditor is registered (if a bank, then an extract from its Charter shall be provide) certified by the notary public or another duly authorized person, and a copy of the Certificate of Filing.

Bank recommendations.

Yearly statements for the past two years certified by the auditing firm with due reflection of assets, liabilities and profits. 
Permission to conduct financial and crediting operations issued by a relevant body in the country where the creditor is registered, or an extract from the relevant legislative act of that country.

Information on past business relations with well-known firms, banks and institutions, as well as samples of credit agreements concluded with other countries, banks and other financial institutions.

\section{Information on the credit proposed to Ukraine}

Currency of the credit.

Sum of the credit (loan).

Duration of the credit (loan).

Interest rates for the credit.

Commission and bonus sums.

Guarantees for the credit extension (provided to creditors) or intentions to provide such a credit (if the credit is proposed by the mediator) confirmed by the bank.

Information on the need for the Cabinet of Ministers of Ukraine guarantees provision for receiving the proposed credit; sample of the guarantee documents in case they are needed.

Information on the possibility of prolonging the credits (loans).

Information on the possibility of receiving credits in other currencies, and on their interest rates.

Information on the documents needed to receive the credit (loan), and their samples.

Information on conditions of provision of the proposed credit (loan).

If a credit (loan) is proposed by an intermediary, a power of attorney (proxy) shall be provided issued in his name by the creditor and certified by the notary public (lawyer). In the said document, the powers of an attorney, signature rights and duration of the proxy shall be clearly defined. 
Annex No. 2

to the Regulations on the Order of Attracting Foreign

Credits and Providing Guarantees of the Cabinet of

Ministers of Ukraine to Secure Obligations of Resident

Legal Persons as to Their Repayment

\section{LIST}

Of Documents To Be Submitted By Resident Legal Person for Receiving A Foreign Credit The Repayment Of Which Is Guaranteed By The Cabinet Of Ministers Of Ukraine And Is Envisaged To Be Implemented On The Currency Self-Repayment Basis

A questionnaire with indication of the object of pledge the value of which should cover the credit amount drawn, taking into account interests and costs of its servicing.

Conclusions of an independent auditor firm on the possibility of sale of the pledged object taking into account the market situation.

Feasibility study report (business plan).

Yearly statement with all supplements certified by an auditor firm, and the statement for the latest accounting date (with a note from the State Tax Administration).

Import contracts for financing of which the foreign currency credit under the guarantees of the Cabinet of Ministers of Ukraine is drawn.

Export contracts and other agreement for sales of products at the expense of which the repayment of the credit and its interest will be effected.

Expert evaluation of prices of import and export contracts and, in case of need, expert evaluation of the project's economic effect.

Calculation of the credit recoupment.

Conclusion of the environmental expert examination (if needed).

Extracts from settlement and currency accounts at the bank rendering these services.

Obligations for opening the settlement and currency accounts in the agent bank and depositing all financial costs there. 
Obligation to submit, on a monthly basis, the information on the status and efficiency of use of the foreign credit received to the National Agency for Reconstruction and Development and Ministry of Economy.

A detailed engineering and technological conclusion from a central executive power body in accordance with the sector, and its research or design institutions regarding the project.

Copies of the enterprise founding documents and Certificate of Filing with the State certified by the notary public.

Notice from the State Tax Administration on the status of settlements with the budget. 
Annex No. 3

to the Regulations on the Order of Attracting Foreign

Credits and Providing Guarantees of the Cabinet of

Ministers of Ukraine to Secure Obligations of Resident

Legal Persons as to Their Repayment

\section{LIST}

Of Documents To Be Submitted By The Resident Legal Person For Receiving Of A Foreign Credit

The Repayment Of Which Is Guaranteed By The Cabinet Of Ministers Of Ukraine And Is

Envisages To Be Effected At The Expense Of State Budget Costs

A questionnaire with indication of the object of pledge the value of which should cover the credit amount drawn, taking into account interests and costs of its servicing.

Conclusions of an independent auditor firm on the possibility of sale of the pledged object taking into account the market situation.

Feasibility study report (business plan).

Yearly statement with all supplements certified by an auditor firm, and the statement for the latest accounting date (with a note from the State Tax Administration).

Import contracts for financing of which the foreign currency credit under the guarantees of the Cabinet of Ministers of Ukraine is drawn.

Export contracts and other agreement for sales of products at the expense of which the repayment of the credit and its interest will be effected.

Expert evaluation of prices of import and export contracts and, in case of need, expert evaluation of the project's economic effect.

Calculation of the credit recoupment.

Conclusion of the environmental expert examination (if needed).

Extracts from settlement and currency accounts at the bank rendering these services.

Obligations for opening the settlement and currency accounts in the agent bank and depositing all financial costs there. 
Obligation to submit, on a monthly basis, the information on the status and efficiency of use of the foreign credit received to the National Agency for Reconstruction and Development and Ministry of Finance.

A detailed engineering and technological conclusion from a central executive power body in accordance with the sector, and its research or design institutions regarding the project.

A document certifying that the project was agreed upon with the Ministry of Finance.

A detailed technical and technological conclusion regarding the project from a central executive power body in accordance with the sector, and its research or design institutions.

Copies of the enterprise founding documents and Certificate of Filing with the State certified by the notary public.

Notice from the State Tax Administration on the status of settlements with the budget. 
Appendix C

Staff Capabilities and Budget 


\section{Appendix C}

\section{Staff Capabilities and Budget}

This appendix provides a description of the proposed responsibilities of the Interdepartmental Commission and Project Implementation Organization (PIO), as well as a listing of the staff capabilities and budget used to develop the 5-year budget of $\$ 3.5$ million for the PIO discussed in Chapter 7 . The authors recognize that the capability mix and budget for the PIO may be different than presented here, but this estimate provides a starting point for developing the final staffing mix and budget.

\section{C.1 Interdepartmental Commission Responsibilities}

The Interdepartmental Commission provides management oversight for operation of the project activities through the Organization Responsible for the Project.

The Interdepartmental Commission may be composed of representatives from the:

- Cabinet of Ministers

- World Bank

- State Committee for Energy Conservation

- Ministry of Finance

- Ministry of Economy

- National Agency for Reconstruction and Development

- Eximbank of Ukraine

- Kyiv Municipal Budget Authority

- Kyiv Municipal Department of Health

- Ministry of Education 
- Kyiv Municipal Department of Education

- Kyiv Municipal Department of Culture

Some of the above organizations may be more actively involved than others in the Interdepartmental Commission's activities-perhaps designated as voting members and observers.

The Interdepartmental Commission designates one to three staff to interface with the PIO. A major responsibility will be oversight for disbursement of the loan. Other responsibilities will be to communicate with the PIO members and resolve institutional issues in the lending and implementation/installation process.

The Interdepartmental Commission convenes/conducts semi-annual meetings to review/discuss:

- Installation status such as the number of buildings retrofitted, cost/price of the measures, energy efficiency improvement (verification).

- Financial status of the investment made and planned, amount of the loan disbursed, and loan service. It is anticipated that the financial status segment will be accompanied by a report from an independent auditor.

- Other items such as the domestic manufacture of goods and environmental issues.

- Other problems and suggested resolutions.

The Interdepartmental Commission will have final approval over all contracts and will provide recognition and incentives.

\section{C.2 PIO Responsibilities}

The PIO will have day-to-day responsibility for administering the project. The PIO reports to the Organization Responsible for the Project and works on a daily basis with the designee(s) of the Oversight Committee.

Areas of the PIO's activities include:

- Loan Disbursement and Service

- Originates disbursement requests.

- Tracks financial status of loan balance to recipient organizations.

- Statuses loan service. 
- Scheduling

- Selects buildings and timing for installation.

- Satisfies sampling and installation requirements to pre-test measures for future years' installations.

- Provides communication/coordination with owning agency, individual building managers, and building occupants.

- Audit

- Develops/specifies audit requirements and procedures; tailors audit to building types as necessary.

- Provides support/assistance for the conduct of the audit, at least in the first year.

- Provides for an independent review of audit recommendations; at least for those that are out of the ordinary.

- Design

- Monitors design process to ensure design bureau is involved and provides approval.

- Installation

- Provides approval for installation to proceed.

- Monitors installation process to ensure minimal disruption to occupants, satisfaction (building manager and occupant) with the installation process, and general quality/efficiency.

- Provides inspection, certification, and acceptance of a completed installation.

- Training and Assistance

- Develops necessary training materials and provides necessary training to building managers.

- Provides assistance to building managers for the operation of "active" systems.

- Provides feedback to building managers on energy and cost performance of operations.

- Verification

- Develops verification protocol; tailors to building types as necessary.

- Conducts or provides certification of verification activity.

- Provides feedback from verification to audit, installation, and training activities. 
- Assistance to Organization Responsible for the Project and the Oversight Committee:

- Notifies representative of accepted installations for loan disbursement and loan service purposes.

- Prepares and presents semi-annual report of installations and financial status.

\section{C.3 PIO Staff Responsibilities}

Brief descriptions of the responsibilities of the PIO staff are provided below.

Manager/Director. Responsibilities include:

- Provides planning, management, and coordination of PIO work.

- Coordinates/supervises project activities to ensure meeting of project strategy, budget and procedure requirements.

- Provides reporting and communication to the oversight/management organization.

- Reviews terms of reference, specification lists and other documents prepared by the PIO to ensure preparation to meet required procedures necessary for signing of contracts with suppliers of equipment, materials, and services.

- Organizes and conducts regular meetings to review and status PIO activities.

Administrative Assistant. Responsibilities include:

- Provides day-to-day oversight for the operation of the office. In addition, this person directly supports the manager/director through tracking actions, understanding procurement issues, and coordination of resources.

- Provides day-to-day assistance to the manager/director of the PIO by tracking actions, understanding procurement issues, and coordination of resources.

- Acts on behalf of the manager/director in their absence.

- Participates in the elaboration of the activities, plans, and budgets.

- Leads preparation of the status reports on the physical and financial progress of the project.

- Possesses the capability and confidence of the manager/director to make decisions regarding the conduct of the office. 
Secretarial/Clerical. Responsibilities include:

- Prepares letters, reports, and other documents for the Project Management Organization.

- Processes and circulates working papers.

- Administers the filing system.

- Schedules and provides records of meetings.

- Coordinates travel arrangements.

- Coordinates translation services.

- Possesses knowledge of office hardware and software (word processing, spreadsheet, and presentation programs).

Accountant. Responsibilities include:

- Tracks and prepares budgets, procurements, and financial reports.

- Monitors project preparation and implementation expenditures and costs; maintains project accounting system.

- Keeps expenditure information current to inform the Ministry of Finance on the status of the loan service.

- Monitors progress of Project Management Organization to regularly update budget forecasts.

- Prepares contract payment terms and all financial arrangements, purchase orders, and other financial documents (together with project administrator and procurement specialist); supervises conformity with project preparation and implementation requirements and project budgets.

- Maintains all financial records.

- Oversees operation of special bank accounts.

- Signs all disbursement requests prior to submission for final signature.

Procurement. Responsibilities include:

- Is responsible for all procurement actions by the Project Management Organization. 
- Is familiar with World Bank procurement requirements and can expect to be involved in the issuance of six to eight major procurement actions the first year and a like number of smaller procurement actions in each of the subsequent years.

- Draws upon the technical resources that exist in the Project Management Organization and draws upon external resources as necessary to prepare procurements and evaluate bidding documents.

- Checks equipment lists provided by the technical staff of the Project Management Organization and ensures their conformity with project requirements and budget.

- Checks all bidding documentation prior to submission to the World Bank for "no objection."

- Advertises bidding, seeks sources of goods, and prepares a short list of eventual suppliers.

- Organizes the receipt and opening of bids, prepares and ensures application of evaluation procedures, prepares background information for negotiations with selected suppliers, and checks contract conditions.

- Ensures the contract award conforms with project requirements and budget.

- Arranges customs clearance and delivery of goods.

- Maintains procurement registry.

- Participates in the preparation of short list and evaluation criteria for the recruitment of consultants.

- Prepares other technical assistance documents (letters of invitation, questionnaires, draft contracts, etc.) and ensures conformity with project requirements and budget.

- Monitors procurement-related activities to ensure that schedules for various activities are on track.

- Prepares time tables for procurement and installation.

- Prepares semi-annual reports on the status of procurement activities.

- Checks conformity of equipment lists, specifications, and their procurement and installation plans to related technical assistance plans and time tables. 
Scheduler. Responsibilities include:

- Works with the various agencies, individual building occupants and operators, and installers to schedule the installation of the energy efficiency equipment/measures. The objective is to minimize disruption to the building occupants during the installation process.

Audit Approval. Responsibilities include:

- Is responsible for initially preparing the audit process employed for evaluating and selecting the energy efficiency equipment/measures.

- Subsequently, will be responsible for reviewing and approving the audits submitted for the installation of specified equipment and measures.

Q/A - Acceptance. Responsibilities include:

- Inspects, certifies, and accepts/rejects each installation. It is anticipated that this function will be performed in close cooperation with staff of the recipient agencies.

- Provides the first signature to disburse payment.

Trainer. Responsibilities include:

- Prepares, coordinates, provides (or assists in providing), and evaluates information and training programs for building occupants and operators.

Verification. Responsibilities include:

- Oversees and conducts data collection and analysis to verify energy efficiency improvements.

It is anticipated that excellent communication and exchange will occur among all staff in the Project Management Organization. Such communication will be especially important among the latter four positions to ensure the highest possible quality installation of energy efficiency equipment/measures.

\section{C.4 PIO Example Budgets}

The estimated labor rates per full-time equivalent (FTE) for the Project Management Organization staff are presented in Table C.1. The annual quantity of labor by staff member and costs for this labor are presented in Table C.2. This shows the annual budget for the Project Management Organization decreasing from over $\$ 1$ million per year to about $\$ 700$ thousand per year despite an increase in the number of staff. The reason for this is due to the higher cost of the foreign consultants, which provides 
Table C.1. Project Management Organization Staff Estimated Labor Rates

\begin{tabular}{||l|c|c|}
\hline \multicolumn{3}{|c|}{ Estimated Cost per FTE (\$1,000) } \\
\hline & Ukrainian & Foreign \\
\hline Manager/Director & 38 & 250 \\
\hline Administrative Assistant & 29 & 175 \\
\hline Secretarial/Clerical & 19 & 125 \\
\hline Accountant & 29 & 175 \\
\hline Procurement & 29 & 200 \\
\hline Scheduler & 29 & 200 \\
\hline Audit Approval & 29 & 200 \\
\hline Q/A - Acceptance & 29 & 200 \\
\hline Training & 29 & 200 \\
\hline Verification/Evaluation & 29 & 200 \\
\hline
\end{tabular}

for a greater decrease in cost with the decrease in number of foreign consultants than the increase in cost associated with the increasing number of Ukrainian staff.

\section{C.5 Potential Consultant Support}

The PIO staff may be supported by consultants procured individually or through a single organization such as an ESCO. The nature of this project (multitechnology installation, several hundred buildings retrofitted annually, several government institutions, performance over 4-year period) will require 1) substantial knowledge of all efficiency technologies evaluated, 2) proven management skills in field installation of equipment and measures, 3) knowledge of procurement processes under World Bank regulations, and 4) knowledge of contracting methods and principles.

\section{Short-Term Technical Consultants}

Procurement of short-term consultants working directly with the PIO will be required for the processing of short-term, high-volume tasks including 1) prequalification of bidders, 2) preparation of bidding documents for supply of materials, labor, and technical services such as building screening and energy audits, 3) evaluation of received bids and selecting contractors and suppliers, and 4) scheduling and management of some installation activity in cooperation with the GC. Procurement of consultants shall follow the ICB rules set forth in the Guidelines (World Bank 1996). Their prequalification shall be completed prior to loan negotiation. 


\begin{tabular}{|c|c|c|c|c|c|c|c|c|c|c|c|c|c|c|c|c|}
\hline $\mathcal{E}[S E$ & EIS & OS & $\varepsilon 9 t$ & $\varepsilon[S$ & 05 & $\varepsilon 9 t$ & $\varepsilon 19$ & OSI & $\varepsilon 9 t$ & $\varepsilon \succsim \varepsilon 6$ & SZ9SS & $9 \angle \varepsilon$ & 81156 & s2'969 & $\sin z$ & 1500 je10L \\
\hline so\&s & $6 L$ & 05 & $6 z$ & $6 L$ & $0 S$ & 62 & 621 & $00 \mathrm{I}$ & $6 z$ & 621 & 001 & 62 & $5+11$ & 001 & $\varsigma+1$ & 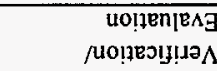 \\
\hline$\varsigma 0 \varepsilon \mathcal{L}$ & $6 z$ & 0 & 62 & $6 z$ & 0 & $6 z$ & $6 z$ & 0 & 62 & $6 L$ & OS & 62 & $\varsigma+9$ & $0 \varsigma$ & $s+1$ & 8ิu!u!̣es \\
\hline$\varsigma \varepsilon 8 t$ & $\angle 8$ & 0 & $\angle 8$ & $\angle 8$ & 0 & $\angle 8$ & $\angle 8$ & 0 & $\angle 8$ & $8 \$ I$ & 001 & 85 & $5+9$ & OS & $\xi \varpi l$ & วoueldวอว - $\forall / \circlearrowright$ \\
\hline $8+s$ & $\angle 8$ & 0 & $\angle 8$ & $\angle 8$ & 0 & $\angle 8$ & $\angle 8$ & 0 & $\angle 8$ & $8 S I$ & 001 & $8 \varsigma$ & $6 Z I$ & 001 & $6 z$ & [enosdd $\vee$ ]! pn $\vee$ \\
\hline 192 & 85 & 0 & 85 & $8 S$ & 0 & 85 & 85 & 0 & $8 \mathrm{~S}$ & 85 & 0 & $8 \varsigma$ & 62 & 0 & $6 z$ & IE|กрәчРS \\
\hline$z z s$ & $8 S$ & 0 & $8 S$ & $8 S$ & 0 & 85 & 801 & $0 S$ & $8 \mathrm{~S}$ & 621 & $00 \mathrm{I}$ & 62 & 691 & $0+1$ & $6 z$ & juaนว.nวогd \\
\hline SL $88 \mathrm{I}$ & 62 & 0 & 62 & 62 & 0 & $6 z$ & 62 & 0 & 62 & $6 z$ & 0 & 62 & $S L Z L$ & SLEt & 62 & 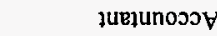 \\
\hline 56 & $6 \mathrm{I}$ & 0 & $6 !$ & 61 & 0 & 61 & 61 & 0 & $6 I$ & $6 \mathrm{I}$ & 0 & 61 & 61 & 0 & $6 I$ & 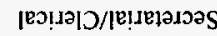 \\
\hline$s \tau 9 L Z$ & 62 & 0 & $6 z$ & 62 & 0 & 62 & 62 & 0 & $6 \tau$ & $S L Z L$ & $S L \varepsilon t$ & 62 & s.11 & $\varsigma<8$ & 62 & 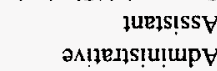 \\
\hline \multirow[t]{12}{*}{$S^{\prime} L L E$} & $8 \varepsilon$ & 0 & $8 \mathfrak{E}$ & $8 \varepsilon$ & 0 & $8 \mathcal{E}$ & $8 \varepsilon$ & 0 & $8 \varepsilon$ & $\varsigma^{\circ} 001$ & $\varsigma 29$ & $8 \varepsilon$ & $\varepsilon 9 \mathrm{I}$ & $\varsigma Z I$ & $8 \varepsilon$ & 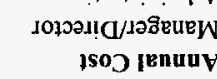 \\
\hline & SZ91 & 520 & 91 & $s 291$ & 520 & 91 & $S L^{\prime} 91$ & $S L^{\prime} 0$ & $9 \mathrm{I}$ & $S\lfloor S I$ & $S L Z$ & $\varepsilon 1$ & 5611 & $S+\mathcal{E}$ & 58 & G.LA [E10I \\
\hline & $s Z^{\prime} I$ & st'0 & 1 & $S Z^{\prime} I$ & $\varsigma Z^{\prime} 0$ & 1 & si & s'o & 1 & $S^{\prime} I$ & $\varsigma^{\circ} 0$ & 1 & I & $\varsigma^{\prime} 0$ & so & 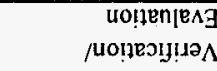 \\
\hline & 1 & 0 & 1 & I & 0 & I & I & 0 & 1 & $s \tau^{\circ}$ & szo & 1 & $S L O$ & sio & $s_{0} 0$ & 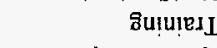 \\
\hline & $\varepsilon$ & 0 & $\varepsilon$ & $\varepsilon$ & 0 & $\varepsilon$ & $\varepsilon$ & 0 & $\varepsilon$ & $s z$ & $\varsigma^{\circ} 0$ & $\tau$ & $\varsigma \angle 0$ & $s Z_{0}$ & so & 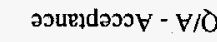 \\
\hline & $\varepsilon$ & 0 & $\varepsilon$ & $\varepsilon$ & 0 & $\varepsilon$ & $\varepsilon$ & 0 & $\varepsilon$ & $s z$ & $\varsigma_{0}$ & $\tau$ & sil & 50 & 1 & [Esosdd $\forall$ נ!pn \\
\hline & $z$ & 0 & $\tau$ & $\tau$ & 0 & $z$ & $\tau$ & 0 & $\tau$ & $\tau$ & 0 & $\tau$ & I & 0 & I & ІвепрәчэS \\
\hline & $\tau$ & 0 & $\tau$ & $z$ & 0 & $\tau$ & $s Z Z$ & sto & $z$ & $S^{\prime} I$ & $\varsigma_{0}$ & 1 & 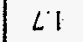 & LO & I & јนวแวเกวо $\perp_{d}$ \\
\hline & I & 0 & 1 & 1 & 0 & I & I & 0 & I & 1 & 0 & 1 & sZI & szo & 1 & วuEjunoวว \\
\hline & l & 0 & 1 & 1 & 0 & I & I & 0 & I & 1 & 0 & l & I & 0 & $\mathrm{I}$ & 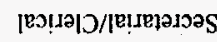 \\
\hline & I & 0 & I & I & 0 & $i$ & 1 & 0 & $i$ & $s t^{\prime}$ & szo & i & SI & $\varsigma_{0}$ & $i$ & 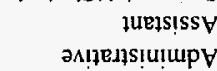 \\
\hline & I & 0 & 1 & $!$ & 0 & I & I & 0 & I & $s z I$ & $s Z^{\circ} 0$ & 1 & 51 & so & słuapeṣnb & 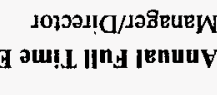 \\
\hline \multirow{2}{*}{$\begin{array}{c}\text { TVIOLL } \\
\text { z00Z-866I }\end{array}$} & [B]O.L & uริ!̣อ10 & แв!ฺ!в. & E10L & นใ! & 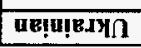 & $1670 \mathrm{~L}$ & 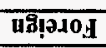 & 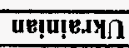 & 1B70L & แิి!a.10 & 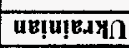 & $1670 . \mathrm{L}$ & uร! & UE!U!̣E.AY & \multirow[t]{2}{*}{ 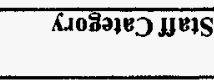 } \\
\hline & \multicolumn{3}{|c|}{2002} & \multicolumn{3}{|c|}{$100 \tau$} & \multicolumn{3}{|c|}{$000 z$} & \multicolumn{3}{|c|}{$666 \mathrm{I}$} & \multicolumn{3}{|c|}{8661} & \\
\hline
\end{tabular}

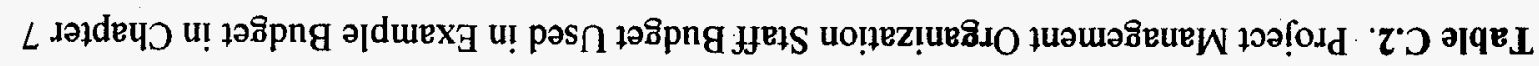




\section{Accounting and Financial Audit Services}

Accounting services will be required for performing major financial transactions, payroll services, and preparation of periodic financial statements. A reputable accounting firm must be employed to periodically audit book entries and financial statements. This service should be procured according to ICB rules.

\section{Legal Advisory Services}

A consultant for legal matters is needed to assist the PIO with all legal issues, including issues related to bidding, contracting, litigation, and other issues as required. A legal consultant/firm shall be procured according to ICB rules set forth in the Guidelines (World Bank 1996). The contract shall be on an annual, as needed basis.

\section{Technical Audit Support}

Technical Audit Support (TAS) will be required for ensuring that the workmanship, delivered materials, equipment, and services are of highest quality and in compliance with project specification. TAS is a second level, independent quality control. It will be contracted to perform scheduled and unannounced audits of the installation sites to verify the quality of installation and the effectiveness of the quality assurance (QA) team. The TAS shall be procured according to ICB rules set forth in the Guidelines (World Bank 1996).

\section{Training Services}

Installation teams, operators, and maintenance personnel of certain technologies will require training. Also, for most of the energy conservation measures to be effective, the technology must be installed according to the manufacturers' specifications and with good quality workmanship. It is generally acknowledged that insufficient quality of workmanship can substantially reduce achieved savings and negatively influence the economics of the project. Therefore, the training activity is essential to the success of the project.

Training is usually best performed by the manufacturers or certified installers of the supplied technology or material. Therefore, it is recommended that these services be procured in relation to the selected supplier. The most effective method of procurement is direct contracting with the supplier who was selected, based on ICB rules or IS rules, to supply the material or technology. Alternatively, training services may be included as part of the equipment procurement. 


\section{Quality Assurance Services}

The QA team will be responsible for inspecting and accepting received equipment and materials, and for accepting the work performed by the contractors. Payment for work will depend on acceptance of the work by the QA team. The QA team should be organized with significant involvement of foreign consultants to ensure international quality standards of all accepted job sites. QA services shall be procured under ICB rules. To ensure that international workmanship quality standards are communicated to the emerging local business, it would be advisable to request preferential treatment for bids that include both foreign and local personnel.

\section{Performance Verification Services}

It is recommended that an energy efficiency company having proper experience in verification of savings obtained by energy conservation technologies be employed to provide required measurements and tests and to collect statistical information on energy consumption by buildings included in the project. It is recommended that the verification procedure be performed according to the North American Energy Measurement and Verification Protocol (NEMVP) (DOE 1996). Verification procedures will be initiated by collecting baseline information during the heating season prior to the installation of efficiency measures. Normalized energy consumption data (i.e., recalculated for appropriate weather data and for any changes in the building occupation schedules) during the first 2 years (heating seasons) after the installation of energy efficiency technologies will be collected, and the energy savings will be evaluated. The results of the evaluation will be used for verification of estimated savings.

It is recommended that this work be done by a consulting firm with a proven record in projects involving verification procedures based on the NEMVP. Consultants/firms will be procured under ICB rules. It would be desirable that foreign bidders involve in-country consultants for the purpose of knowledge transfer, and $15 \%$ preferential treatment for bids involving local personnel will be requested for approval by the World Bank. 
Appendix D

Bidding Specifications 


\section{Appendix D}

\section{Bidding Specifications}

The following technical specification pages will be part of each individual bidding package. Technical specification is to be completed after all project details are available. The technical specification of materials is site-specific, and its completion requires a site audit, design, and specification. It is the World Bank's general policy that at least the first year's procurement packages are prepared prior to negotiation of the loan. Technical specification of materials to be included in bidding packages for procurement during the first year will be prepared prior to loan negotiation. 


\title{
Technical Specification (1)
}

\author{
Project Name: Kyiv International Building Assessment (KIBA) \\ Name of Item: $\quad$ Radiator reflector \\ Quantity: \\ 227,894
}

\section{Technical Description}

1. General Description - Radiator reflectors are installed on the wall behind radiators of hot water heating systems in buildings. Wall surfaces are mostly mortar based and are sometimes covered with regular wall paper. The purpose of the reflectors is twofold: 1) reflect the radiant portion of heat directed to the wall back to the room space, and 2) insulate the part of the wall directly behind the radiator. Because the size of each radiator may vary, reflector foil is typically cut to size during the installation. Therefore, it is preferred that the material is provided in a continuous roll.

Material shall be constructed of at least an insulation layer and a reflecting layer. The insulation material shall be at least $3 \mathrm{~mm}$ thick. The foil should have high reflection properties and may be made of plastic material or metal.

Insulation will be applied directly to the wall and will cover approximately the wall area equivalent to the face area of the radiator. It shall be easy to apply and easy to attach to the wall surface. Either a self-adhesive design or the use of a liquid adhesive or installation tape is acceptable.

2. Technical Specification

Material Properties: Nontoxic, nonasbestos, stable under normal ambient and/or operating conditions. Material shall withstand temperatures up to $60^{\circ} \mathrm{C}$. The surface of the material of the external foil shall be highly reflective, and shall retain such property throughout its useful life.

Thermal Property: Minimum R-value of the insulation material shall be $0.1 \mathrm{~m}^{2} \mathrm{~K} / \mathrm{W}$.

Dimensions: The material shall be made according to standard dimensions of the manufacturer. The material is expected to have an overall thickness in the range of 3 to $5 \mathrm{~mm}$ and width in the range of 0.9 to $1.2 \mathrm{~m}$, with continuous length.

Compliance: The material and all components necessary for its transportation, handling, and application shall comply with applicable Ukrainian codes. 
Expected Life: It is required that the insulation material will not deteriorate or otherwise lose its thermal insulation properties and reflective properties in fewer than 5 years.

3. Tools or Other Required Items - The material of the reflector shall be supplied with sufficient hardware, installation material, fasteners, solvents, or any other items necessary for complete installation. Should special tools or simple jigs be required for the installation, such shall be provided with the material. Other expensive or otherwise special tools and/or equipment shall be specified in the offer and the price of such shall be provided.

4. Maintenance Requirements - Once properly installed, radiator reflectors are not expected to require maintenance.

5. Manuals and Data sheets - Standard and special installation and operating instructions shall be provided for the radiation reflectors and for all components, as required by standard manufacturer's policy. Material safety data sheets shall be provided.

6. Warranty Specification - Goods offered shall be covered by manufacturer's standard warranty, or for at least 12 months from the date of delivery to purchaser, whichever is longer.

7. Special Packing, Marking, and/or Delivery Instruction - Goods shall be properly packaged for the best and the most economical means of transportation from the manufacturer to the destination in Kyiv, Ukraine. Packaging shall protect the material from weather and ordinary means of handling. Marking and labeling of the material and its packaging shall be in accordance with the manufacturer's standards. 


\title{
Technical Specification (2)
}

\author{
Project Name: $\quad$ KIBA \\ Name of Item: Weatherstripping -V-seal \\ Quantity: $\quad 1,200$ meters
}

\section{Technical Description}

1. General Description - Windows in all types of buildings have at least a part of the total fenestration area openable. The size and shape of the gap between the fixed and moveable part of the window depends on window construction, workmanship during the fabrication, and on the general condition of the window. Some fixed gap (approximately 2 to $3 \mathrm{~mm}$ ) is required for the window opening to compensate for the hinge offset. Depending on the gap size and its length (its total cross-flow area), a substantial airflow can penetrate the window, resulting in heat losses.

The purpose of installing the V-seal is to minimize air flow through the gap and thus lower the heat losses due to such infiltration. V-seal is installed all around the external side of the moving window frame such that the tip of the V-seal is directed toward the outside. The V-seal is flexible and when the window is closed, it fills the gap. One side of the V-seal is firmly attached to the moving window frame, the other side is pressed against the fixed window frame surface.

2. Technical Specification

Material Properties: The material can be plastic or metal substrate, and shall be nontoxic, nonasbestos, and stable under normal ambient conditions. The material of the V-seal must be flexible, sufficiently durable for the application and shall maintain its properties under normal and extreme ambient temperatures. Materials such as polyethylene, polypropylene, Teflon, polycarbonates, or similar materials are acceptable. One-half of the seal width shall have a selfadhesive surface covered with protecting paper foil.

Thermal Property: Material shall withstand temperatures from -30 to $+60^{\circ} \mathrm{C}$.

Dimensions: $\quad$ Material shall be $0.3 \mathrm{~mm}$ minimum thickness, $1 \mathrm{~cm}$ wide (each "leg") and supplied in rolls of at least $\mathbf{5 0}$ meters long. V-seal material should be delivered in flat form, with crimp in the middle of its width for easy forming.

Expected Life: It is required that the useful life of the V-seal, properly installed, will be no fewer than 5 years. 
3. Tools or Other Required Items - If applicable, the V-seal shall be supplied with sufficient quantities of hardware, installation material, fasteners, solvents or any other items necessary for complete installation. Should special tools or simple jigs be required for the installation, such shall be provided with the material. Other expensive or otherwise special tools and/or equipment shall be specified in the offer and the price of such shall be provided.

4. Maintenance Requirements - Once properly installed, V-seal or any of its components shall not require maintenance.

5. Manuals - Standard and special installation and operating instructions shall be provided for the $\mathrm{V}$-seals and for all components, as required by standard manufacturer's policy. Material safety data sheets shall be provided.

6. Warranty Specification - Goods offered shall be covered by manufacturer's standard warranty, or for at least 12 months from the date of delivery to purchaser, whichever is longer.

7. Special Packing, Marking, and/or Delivery Instruction - Goods shall be properly packaged for the best and the most economical means of transportation from the manufacturer to the destination in Kyiv, Ukraine. Packaging shall protect the material from weather and ordinary means of handling. Marking and labeling of the material and its packaging shall be according to manufacturer's standards. 


\title{
Technical Specification (3)
}

\author{
Project Name: $\quad$ KIBA \\ Name of Item: Weatherstripping - EPDM seal, "P" shape \\ Quantity: $\quad 1,200$ meters
}

\section{Technical Description}

1. General Description - Windows in all types of buildings have at least a part of the total fenestration area openable. The size and shape of the gap between the fixed and moveable part of the window depends on window construction, workmanship during the fabrication, and on the general condition of the window. Some fixed gap (approximately 2 to $3 \mathrm{~mm}$ ) is required for the window opening to compensate for the hinge offset. Depending on the gap size and its length (its total cross-flow area), a substantial airflow can penetrate the window, resulting in heat losses.

The purpose of installing the EPDM seal is to minimize air flow through the gap and thus lower heat losses due to such infiltration. The EPDM seal is installed all around the opening on the internal side of the fixed window frame in areas covered by the moveable frame flange (when window is closed). The EPDM seal is flexible, and when the window is closed, the seal is lightly squeezed between the frames. One side of the EPDM seal is firmly attached to the fixed window frame via a self-adhesive surface.

2. Technical Specification

Material Properties: The material shall be white, beige or other neutral color of soft EPDM, nontoxic, nonasbestos, and stable under normal ambient conditions. The material of the seal must be flexible, sufficiently durable for the application, and shall maintain its properties under normal and extreme ambient temperatures.

Thermal Property: Material shall withstand temperatures from -30 to $+60^{\circ} \mathrm{C}$.

Dimensions: $\quad$ The seal shall be hollow type with a flat surface on at least one side with a self-adhesive surface. The round part of the seal profile shall have a diameter of $5 \mathrm{~mm}$ and a wall thickness of $0.6 \mathrm{~mm}$. The "leg" shall be $10 \mathrm{~mm}$ long with a wall thickness of $0.8 \mathrm{~mm}$. The seal shall be supplied in a continuous length of at least $50 \mathrm{~m}$.

Expected Life: It is required that the useful life of the EPDM-seal, when properly installed, will be no fewer than 5 years. 
3. Tools or Other Required Items - If applicable, the EPDM seal shall be supplied with sufficient hardware, installation material, fasteners, solvents, or any other items necessary for complete installation. Should special tools or simple jigs be required for the installation, such shall be provided with the material. Other expensive or otherwise special tools and/or equipment shall be specified in the offer and the price of such shall be provided.

4. Maintenance Requirements - Once properly installed, the EPDM seal or any of its components shall not require maintenance.

5. Manuals - Standard and special installation and operating instructions shall be provided for the EPDM seal and for all components, as required by standard manufacturer's policy. Material safety data sheets shall be provided.

6. Warranty Specification - Goods offered shall be covered by manufacturer's standard warranty, or for at least 12 months from the date of delivery to purchaser, whichever is longer.

7. Special Packing, Marking, and/or Delivery Instruction - Goods shall be properly packaged for the best and the most economical means of transportation from the manufacturer to the destination in Kyiv, Ukraine. Packaging shall protect the material from weather and ordinary means of handling. Marking and labeling of the material and its packaging shall be according to manufacturer's standards. 


\section{Technical Specification (4)}

Project Name: $\quad$ KIBA

Name of Item: Weatherstripping - Silicone tubes

Quantity: $\quad$ purchased in lots of 500; number of lots unknown

\section{Technical Description}

1. General Description - Silicone material is required for sealing various gaps and cracks between the wall and window frame materials, cracks in walls close to the windows, cracks in the window frame, etc. It will be applied manually using a dispensing gun.

2. Technical Specification - Clear drying silicone acrylic latex, in $0.25-$ to $0.5-\mathrm{kg}$ tubes with dispensing tip. Material must be printable, UV-resistant, resilient, weather resistant, and shall withstand ambient temperatures from -40 to $+100^{\circ} \mathrm{C}$.

3. Tools or Other Required Items - One dispensing gun of industrial quality shall be provided for each 100 tubes.

4. Manuals and Data Sheets - Standard and special installation instructions shall be provided for the silicon tubes and for all components, as required by standard manufacturer's policy. Material safety data sheets shall be provided.

5. Warranty Specification - Goods offered shall be covered by manufacturer's standard warranty, or for at least 12 months from the date of delivery to purchaser, whichever is longer.

6. Special Packing, Marking, and/or Delivery Instruction - Goods shall be properly packaged for the best and the most economical means of transportation from the manufacturer to the destination in Kyiv, Ukraine. Packaging shall protect the material from weather and ordinary means of handling. Marking and labeling of the material and its packaging shall be according to manufacturer's standards. 


\section{Technical Specification (5)}

NOTE: The specification and costs for space heating substation equipment are dependent upon the system capacity and configuration. Therefore specifications and costs can only be prepared on a building-by-building basis (i.e., they are not necessarily replicable across buildings).

Project Name: $\quad$ KIBA

Name of Item: $\quad$ Space heating substation equipment

Quantity: $\quad 1,678$

\section{Technical Description}

1. General Description - The building space heating system currently uses a hydroelevator (venturi nozzle) system for water circulation control within the building. Such systems allow district heating water to be directly circulated in the building heating system and assume constant district heating system pressure. These systems are outdated, inefficient, and do not offer proper capacity control ability and need to be replaced. The heating distribution system is constructed as single pipe, multiple branch (riser), with steel or cast iron radiators. Radiators are equipped with manual shut-off valves, which are in most cases fully open and inoperable.

The retrofit of the space heating substation assumes that all existing hydroelevator equipment will be removed and replaced with a water-to-water heat exchanger type system, thus creating a closed-loop building heating system equipped with all necessary components and equithermic heating capacity control based on outdoor temperature. Equithermic control maintains constant flow and modulates the space heating water temperature based on the outdoor conditions. The retrofit plan expects that the following steps are necessary:

- Complete removal of the existing substation equipment between a building heat meter on one side, and the distributing manifold on the other side, and replacement with new substation equipment. Some parts of the existing piping may be in good condition and may be used as applicable.

- Installation of manual balancing valves into each riser and consequent balancing of the entire building heating system. If possible, balancing valves will be installed within the substation room close to the main distribution manifold. It is expected that existing shut-off valves in each riser are in good condition and are usable. The condition of these valves and the potential need to replace them shall be determined by the bidder and if applicable, the replacement cost will be included in the bid cost. 
- Chemical cleaning of the building side closed heating loop. Installation of a new heat exchanger requires that the fluids are free of abrasive materials and other contamination (such as rust, floating lime deposits, etc.), which could cause heat exchanger flue blockages and consequent failure.

- Installation and setup of the control system.

- System startup - It is preferred that the substation be supplied pre-assembled, or as a complete packaged unit. However, field installation of separate components is acceptable, providing that each component and each subassembly used is suitable and properly sized. In general, the system will consist of the following components and materials as applicable: water-to-water heat exchanger, circulating pumps, control system (including CPU, sensors, sensor wells, timer, etc.), control valve(s), balancing valves, shut-off valves, filters, check valves, pressure regulator(s), manometers, thermometers, pipes, and wiring. All components shall be industrially manufactured and of standard quality. All energy-consuming equipment shall be rated as high efficiency.

2. Technical Specification

Heat Exchanger: Plate type or shell-and-tube, water-to-water heat exchanger designed for hot water space heating applications. Product specification sheet shall be submitted with the bid.

\begin{tabular}{lccccc} 
& Units & & Primary Side & & Secondary Side \\
\cline { 1 - 1 } \cline { 5 - 6 } \cline { 5 - 6 } Capacity & $\mathrm{kW}$ & & 100 to 300 & & 100 to 3000 \\
Working Fluid & - & & Water & & Water \\
Flow & $\mathrm{m}^{3} / \mathrm{hr}$ & & 1 to 10 & & 5 to 30 \\
Entering Temperature & $\mathrm{C}$ & & 150 & & 70 \\
Leaving Temperature & $\mathrm{C}$ & & 76 & 95 \\
Pressure Drop & $\mathrm{kPa}$ & & 0.1 to 2.0 & & 0.5 to 3.0 \\
Max. Pressure & $\mathrm{kPa}$ & & 30 & & 30 \\
Connecting Pipes Diameter & $\mathrm{mm}$ & & 20 to 120 & & 20 to 120
\end{tabular}

Circulating pump: Specification sheets containing all pump parameters, including dimensions, shall be provided with the bid.

Type:

Mounting:

Construction:

Motor:
High efficiency, industrial grade circulating pump, centrifugal type for closed water heating systems.

Base mounted or in-line installation

In-line radially split body, or dual vault, cast iron body, bronze or steel rotor, upward discharge, horizontal inlet

High efficiency, 0.75 to $15 \mathrm{~kW}, 380 \mathrm{~V}, 50 \mathrm{~Hz}$, TEFC integral 
Pump Performance: 5 to $30 \mathrm{~m}^{3} / \mathrm{hr}$

1 to $5 \mathrm{kPa}$ heat pressure

1725 RPM

Control system: Control system shall be designed for hot water space heating application, outdoor temperature reset, and night setback. All sensors, wiring, and installation hardware shall be included.

Type: $\quad$ Proportional drop/rise electronic temperature reset controller, Celsius scale, surface or DIN rail mounting, LED display, minimum output

Reset Ratio: $\quad 1: 5$ to $3: 1$

Minimum Supply: $\quad 10$ to $71^{\circ} \mathrm{C}$

Output:

SPDT direct or reverse acting

Input Voltage:

$24 \mathrm{VAC}, 50 / 60 \mathrm{~Hz}+/-15 \%, 40 \mathrm{VA} \max$.

Ambient Temp.: $\quad-34$ to $+60^{\circ} \mathrm{C}$

Setback Range: $\quad 0$ to $17^{\circ} \mathrm{C}$

Warm Weather Shut-off: $16,18,20,22$. May be jumper selected

Control valve/motor: The control valve actuator must be compatible with the controller, selected and supplied with the valve body as one assembly.

Motor Type: $\quad$ Nonspring return, minimum force $100 \mathrm{~kg}$

Input: $\quad 24 \mathrm{VAC}$ intermittent, 3-wire for two direction

Valve: $\quad 20$ to $120 \mathrm{~mm}$ diameter

Max. Pressure: , $30 \mathrm{kPa}$

Modulating Char.: $\quad \mathrm{Cv}=0.3$ to 1.5

Shut-off Valve: Manual ball type shut-off valve, 20 to $120 \mathrm{~mm}$ diameter, flanged type, steel body, hot water/steam application.

Balancing Valve: Y-type 12 go $32 \mathrm{~mm}$ NPT connection valve. Positive shut-off with positive memory stop, pressure differential readout ports for balancing, bronze/copper alloy body.

Pressure Regulator: Pressure regulator valve for pressure range 0 to $5 \mathrm{kPa}$, adjustable, 0 to $10 \mathrm{~V} / \mathrm{s}$, 100 to $3000 \mathrm{~kW}$, connection size 38 to $120 \mathrm{~mm}$ threaded or flanged, steel or bronze alloy body, EPDM or metal diaphragm.

Filter: Metal mesh filter for hot water heating systems. Stainless steel mesh, in-line, replaceable cartridge type, flange connection. 
Max. Pressure: $300 \mathrm{kPa}$

Mesh Size: 12

Water Flow: $\quad 5$ to $30 \mathrm{~m}^{3} / \mathrm{hr}$

Check valve: Back-flow preventing check valve, 20 to $120 \mathrm{~mm}$ diameter, full flow ball type, soft seat, pressure differential relief valve, threaded or flange connection, one-directional positive shut off.

Piping: Black piping DN 30 to DN 120,4-m-long pieces, according to DIN standard.

3. Accessories and Attachments - The substation shall be supplied with all necessary accessories and attachments required for proper function, operation, and maintenance.

4. Tools or Other Required Items - The substation assembly and/or all components shall be supplied with sufficient amount of installation hardware, installation material, fasteners, gaskets, chemicals, and other items necessary for complete assembly/installation. Should special tools or simple jigs be required for the installation, such shall be provided with the material and parts. Other expensive or otherwise special tools and/or equipment shall be specified in the offer and price of such shall be provided. Rigging, handling, and assembly equipment and its size shall be clearly specified.

5. Maintenance Requirements - The substation and all its equipment shall require only ordinary routine maintenance and seasonal inspection. Maintenance requirements, such as cleaning, adjustments, lubrication, etc. shall be specified and maintenance personnel sufficiently trained.

6. Spare Parts and Supplies Required - Bidder shall specify all spare parts and supplies necessary for normal operation, and typically stocked for emergency repairs. A list of such parts shall be provided, and the price shall be included in the bid.

7. Manuals - Standard and special installation and operating manuals and instructions shall be provided for all materials, parts, equipment, and components of the assembly or supplied separately, as required by standard manufacturer's policy. Operating manuals for each piece of equipment shall be provided in two copies. Material safety data sheets shall be provided.

8. Warranty Specification - Goods offered shall be covered by manufacturer's standard warranty, or for at least 12 months from the date of delivery to purchaser, whichever is longer.

9. Special Packing, Marking, and/or Delivery Instruction - Goods shall be properly packaged for the best and the most economical means of transportation from the manufacturer to the destination in Kyiv, Ukraine. Packaging shall protect the material from weather and damage due to ordinary means of handling. Marking and labeling of the material and its packaging shall be in accordance with manufacturer's standards. 


\section{Technical Specification (6)}

Project Name: $\quad$ KIBA

Name of Item: Low-Flow Showerhead

Quantity: $\quad 17,313$

\section{Technical Description}

1. General Description - Showerheads installed in the building are designed for regular, unrestricted water flow and, depending on the pressure, require up to $20 \mathrm{l}$ /minute of water. Showerheads have $1 / 2$-inch NPT connection.

2. Technical Specification - Low-flow showerhead with standard $1 / 2$-inch NPT connection, nonremovable flow restricting orifice and aerator. Head may be equipped with stop valve (but this is not necessary). Maximum water flow shall be $10 \mathrm{l} / \mathrm{second}$ at $5.0 \mathrm{kPa}$ inlet water pressure.

3. Accessories and Attachments - Any accessories, such as grommets or seals, shall be included.

4. Tools or Other Required Items - Tools required for installation shall be specified on packaging or in installation instructions.

5. Maintenance Requirements - Showerhead shall not require special maintenance, except regular cleaning.

6. Manuals and Data Sheets - Installation instructions shall be provided.

7. Warranty Specification - Goods offered shall be covered by manufacturer's standard warranty, or for at least 12 months from the date of delivery to Purchaser, whichever is longer. 


\section{Technical Specification (7)}

Project Name: $\quad$ KIBA

Name of Item: $\quad$ Aerator

Quantity: $\quad 59,345$

\section{Technical Description}

1. General Description - Kitchen, bathroom, and other water faucets installed in the building are designed for regular, unrestricted water flow and, depending on the pressure, require up to $40 \mathrm{l}$ /minute of water. Restriction of flow for the "running water" application is desirable. Aerators will be installed in each faucet with proper attachment feature (thread).

2. Technical Specification - Aerator adapter for retrofit application with maximum flow of $10 \mathrm{~V} / \mathrm{min}$ at $5 \mathrm{kPa}$. Connecting via plastic bushing or $1 / 2$-inch FPT.

3. Accessories and Attachments - Any accessories such as grommets or seals shall be included.

4. Tools or Other Required Items - Tools required for installation shall be specified on packaging or in installation instructions.

5. Maintenance Requirements - Showerhead shall not require special maintenance, except regular cleaning.

6. Manuals and data sheets - Installation instructions shall be provided.

7. Warranty Specification - Goods offered shall be covered by manufacturer's standard warranty, or for at least 12 months from the date of delivery to purchaser, whichever is longer. 


\section{Technical Specification (8)}

Project Name: $\quad$ KIBA

Name of Item: Building-Level Heat Meters

Quantity: $\quad 1,678$

\section{Technical Description}

1. General Description - Building heat supply is currently not metered. Heating is provided by the hot water district heating system delivered into a building via black pipes with dimension range DN35 through DN 150 . Water temperature is in the range of 60 to $150^{\circ} \mathrm{C}$. Water flow is site specific.

2. Technical Specification - Heat meter should be supplied with all necessary components, including flow meter, calculating unit, power supply, hot and cold water sensors, sensor wells and all necessary cables and wiring:

Flow Range: $\quad 0$ to $5 \mathrm{~m}^{3} / \mathrm{hr}$

Temperature Range: 40 to $150^{\circ} \mathrm{C}$

Pipe Size: $\quad 20$ to $76 \mathrm{~mm}$

Connection: (flange or NPT)

Maximum Pressure: $30 \mathrm{kPa}$

Output: puls

Accuracy: $\quad+/-.5 \%$ at nominal flow

Battery Pack: 6-year life, $24 \mathrm{~V}$

Power Supply: $\quad 220$ to 24 VAC

3. Accessories and Attachments - Any accessories such as grommets, seals, remote readout (if required) shall be included. Power supply of required parameters shall be supplied. Battery pack for at least a 6-year life should be supplied. Sensors and sensor wells shall be supplied. Installation hardware shall be supplied.

4. Tools or Other Required Items - Tools required for installation shall be specified. Special tools or jigs shall be included with the shipment and their use shall be described in installation instructions.

5. Maintenance Requirements - Heat meters, once installed, shall not require special maintenance.

6. Manuals, Certification, and Data Sheets - Installation instructions shall be provided. Certification of accuracy and all certifications required for use of the heat meter in Ukraine shall be provided.

7. Warranty Specification - Goods offered shall be covered by manufacturer's standard warranty, or for at least 12 months from the date of delivery to purchaser, whichever is longer. 
8. Special Packing, Marking, and/or Delivery Instruction - Goods shall be properly packaged for the best and the most economical means of transportation from the manufacturer to the destination in Kyiv, Ukraine. Packaging shall protect the material from weather and damage due to ordinary means of handling. Marking and labeling of the material and its packaging shall be according to manufacturer's standards. 


\section{Technical Specifications (9)}

NOTE: The system cost depends on the system capacity and specific sizes of all parts (heat exchanger, valves, pump, etc.), which can only be determined for the specific project. A final request for quote can only be prepared with respect to each individual building.

Project Name: $\quad$ KIBA

Name of Item: - Hot Water Heat Exchanger

Quantity: $\quad 1,678$

\section{Technical Description}

1. General Description - The building space and water heating system currently uses a four-pipe arrangement, with two pipes used for space heat and two pipes for domestic hot water. When the hydroelevator space heat system is replaced with a heat exchanger-based closed heating loop, the domestic water heating should also be replaced for two reasons. First, the domestic water heating (DWH) system can be supplied with primary heat from a pipe common to both the space and water heating systems, thus reducing the four-pipe system to a two-pipe system and eliminating substantial losses in pipes. Secondly, a two-pipe system will allow the installation of a single heat meter, which is required in regulations for billing by actual heat consumption. The existing DWH systems are outdated, inefficient, and do not offer proper capacity control ability and need to be replaced.

The retrofit of the DWH systems assumes that all the existing DWH equipment will be removed from the substations (external to the buildings) and replaced with water-to-water heat exchanger-type systems equipped with all necessary components in each building. The retrofit plan includes the following steps:

- Complete removal of the existing equipment from the mechanical room or from the distribution substation and replacement with new DWH equipment installed inside the building.

- Installation of manual balancing valves, water temperature controls, and all necessary safety components, such as pressure relief valves, expansion tanks, mixing valves, etc. It is expected that existing shut-off valves and water meters are in reasonable condition and will not be replaced. The condition of these components and the potential need to replace them shall be determined by the bidder, and if applicable, replacement cost will be included in the bid cost.

- Cleaning the pipes on the domestic water side of the heat exchanger. Installation of a new heat exchanger requires that the fluids are free of abrasive materials and other contamination (such as rust, floating lime deposits, etc.), which could cause heat exchanger flue blockages and consequent failure. Liquid filters shall be installed on both sides of the heat exchanger. 
- System startup. It is preferred that the DWH system be supplied pre-assembled, or as a complete packaged unit. However, field installation of separate components is acceptable, providing that each component and each subassembly used is suitable and properly sized. In general, the system will consist of the following components and materials as applicable: water-to-water heat exchanger, circulating pumps (if a three-pipe system is installed in the building), control system (including CPU, sensors, sensor wells, timer, etc.), control valve(s), shut-off valves, filters, check valves, pressure regulator(s), manometers, thermometers, pipes, and wiring. All components shall be industrially manufactured and of standard quality. All energy-consuming equipment shall be rated as high efficiency.

2. Technical Specification

Heat Exchanger: Plate type or shell-and-tube, water-to-water heat exchanger designed for hot water space heating applications. A product specification sheet shall be submitted with the bid.

\begin{tabular}{lccccc} 
& Units & & Primary Side & & Secondary Side \\
\cline { 1 - 1 } \cline { 5 - 6 } Capacity & $\mathrm{kW}$ & & 20 to 600 & & 20 to 600 \\
Working Fluid & - & & Heating Water & & City Water \\
Flow & $\mathrm{l} / \mathrm{s}$ & & $\mathrm{N} / \mathrm{A}$ & & 3 to 30 \\
Entering Temperature & $\mathrm{C}$ & & 150 & 3 \\
Leaving Temperature & & $\mathrm{C}$ & & 76 & 45 \\
Pressure Drop & $\mathrm{kPa}$ & & 0.2 to 1 & 0.2 to 2 \\
Max. Pressure & $\mathrm{kPa}$ & & 30 & 30 \\
Connecting Pipes Diameter & $\mathrm{mm}$ & 20 to 80 & & 20 to 80
\end{tabular}

Circulating pump (if required): A specification sheet containing all pump parameters, including dimensions, shall be provided with the bid.

Type: $\quad$ High efficiency, industrial grade circulating pump, centrifugal type, for closed Mounting: $\quad$ water heating systems. $\quad$ Base mounted or in-line installation

Construction: In-line radially split body, or dual vault, cast iron body, bronze or steel rotor, upward discharge, horizontal inlet

Motor: High efficiency, 0 to $2 \mathrm{~kW}, 380 \mathrm{~V}, 50 \mathrm{~Hz}, \mathrm{TEFC}$ integral

Pump performance: $\quad 1-6 \mathrm{~m}^{3} / \mathrm{hr}$

1-5 $\mathrm{kPa}$ head pressure

1725 RPM

Control system: The control system shall be designed for flow-through domestic hot water heating applications. All sensors, wiring, and installation hardware shall be included. 
Type:

Variable-flow, constant temperature, electronic temperature controller, Celsius scale, surface or DIN rail mounting, LED display, minimum output adjustment.

Minimum supply: $\quad 35$ to $45 \mathrm{C}$

Output: SPDT direct or reverse acting Input voltage: $\quad 24 \mathrm{VAC}, 50 / 60 \mathrm{~Hz}+/-15 \%, 40 \mathrm{VA} \max$. Ambient temp.: $\quad-34$ to $+60 \mathrm{C}$ Setback range: $\quad 0$ to $10 \mathrm{C}$

Control valve/motor: Control valve actuator(s) must be compatible with the controller, and must be selected and supplied with the valve body as one assembly.

Motor Type: $\quad$ Non-spring return, minimum force $100 \mathrm{~kg}$

Input: 24 VAC intermittent, 3-wire for two direction

Valve: 20 to $80 \mathrm{~mm}$ diameter, two-way modulating motorized valve, flanged, cast iron body, steam/hot water application.

Max. pressure: . $\quad 50 \mathrm{kPa}$

Shut-off valve: Manual ball-type shut-off valve, 20 to $80 \mathrm{~mm}$ diameter, flanged-type, steel body, hot water/steam application.

Pressure regulator: Pressure regulation valve for a pressure range of 0 to $5 \mathrm{kPa}$, adjustable, 0.2 to $3 \mathrm{ls}$, connection size of 20 to $80 \mathrm{~mm}$ threaded or flanged, steel or bronze alloy body, EPDM or metal diaphragm.

Filter: Metal mesh filter for hot water heating systems. Stainless steel mesh, in-line, replaceable cartridge type, flange connection.

Max. Pressure: $\quad 50 \mathrm{kPa}$

Mesh size: $\quad 12$

Water flow: $\quad 0.2$ to $10 \mathrm{l} / \mathrm{s}$

Check valve: Back-flow preventing check valve, 20 - to 80 -mm diameter, full-flow ball type, soft seat, pressure differential relief valve, threaded or flange connection, one-directional positive shut off.

Piping: Black piping DN 20 to 80,4 to $6 \mathrm{ft}$ long pieces, according to DNN standard.

3. Accessories and Attachments - Water heating system shall be supplied with all necessary accessories and attachments required for proper function, operation, and maintenance. 
4. Tools or Other Required Items - The DWH system assembly and/or all components shall be supplied with a sufficient amount of installation hardware, installation material, fasteners, gaskets, chemicals, and other items necessary for complete assembly/installation. Should special tools or simple jigs be required for the installation, these shall be provided with the material and parts. Other expensive or otherwise special tools and/or equipment shall be specified in the offer and the price shall be provided. Rigging, handling and assembly equipment and its size shall be clearly specified.

5. Maintenance Requirements - The DWW station and all its equipment shall require only ordinary routine maintenance and seasonal inspection. Maintenance requirements, such as cleaning, adjustments, lubrication, etc. shall be specified and maintenance personnel sufficiently trained.

6. Spare Parts and Supplies Required - Bidder shall specify all spare parts and supplies necessary for normal operation and typically stocked for emergency repairs. A list of such parts shall be provided and the price shall be included in the bid.

7. Manuals - Standard and special installation and operating manuals and instruction shall be provided for all materials, parts, equipment, and components of the assembly or supplied separately, as required by standard manufacturer's policy. Operating manuals for the equipment shall be provided ( 2 copies). Material safety data sheets shall be provided.

8. Warranty Specification - Goods offered shall be covered by manufacturer's standard warranty, or for at least 12 months from the date of delivery to purchaser, whichever is longer.

9. Special Packing, Marking, and/or Delivery Instructions - Goods shall be properly packed for the best and most economical means of transportation from the manufacturer to the destination in Kyiv, Ukraine. Packaging shall protect the material from weather and damage due to ordinary means of handling. Marking and labeling of the material and its packaging shall be in accordance with manufacturer's standards. 


\section{Technical Specifications (10)}

Project Name: $\quad$ KIBA

Name of Item: Ceiling Fan

Quantity: $\quad 347$

\section{Technical Description}

1. General Description - Halls accommodating a large number of people are typically designed with excessively high ceilings to provide sufficient air supply. High open space causes room temperatures to stratify. As a result, the temperature difference between the floor and the ceiling may be as high as $10^{\circ} \mathrm{C}$, which results in discomfort and space overheating mainly during low and medium occupancy. De-stratification of temperatures in high ceiling spaces is accomplished by application of large-diameter, slow-speed ceiling fans. The use of ceiling fans eliminates the air temperature stratification and reduces temperature losses caused by overheating. In the cooling mode, ceiling fans produce a slight air draft, which delays the use of air conditioning during periods of low cooling demand.

The installation of ceiling fans requires the proper design and selection of the types of fans suitable for an individual application with respect to the interior design. The measure includes the installation of all electrical and control wiring, installation of the fan, and its testing. It is expected that a variety of designs will be used for application in cultural and some other buildings.

2. Technical Specification - All fans and fan designs considered for the application must be of a standard design and have normal approval ratings (UL and/or Ukrainian agency responsible for approval of electrical appliances for general use). Fans must be designed for installation on the ceiling and require no maintenance.

Fan Type: $\quad$ Ceiling fan with or without lighting fixture, large low-speed blades. Motor: $\quad$ Shaded pole, single phase, $220 \mathrm{~V}, 50 \mathrm{~Hz}$.

Material: $\quad$ Any material compatible with electrical and fire prevention codes.

Control: Manual and/or timer.

3. Accessories and Attachments - Any accessories, such as grommets, seals, remote control (if applicable) shall be included. If required, a power supply of required parameters shall be supplied including a battery pack with at least a 6-year life. Sensors (if applicable) and installation hardware shall be supplied.

4. Tools or Other Required Items - Tools required for installation shall be specified. Special tools or jigs shall be included with the shipment and its use shall be described in installation instructions. 
5. Maintenance Requirements - Ceiling fans, once installed, shall not require any special maintenance.

6. Manuals, Certification, and Data Sheets - Installation instructions shall be provided. Certification of compliance with electrical, safety, and fire codes, and all certifications required for the use of the ceiling fans in Ukraine shall be provided.

7. Warranty Specification - Goods offered shall be covered by manufacturer's standard warranty, or for at least 12 months from the date of delivery to purchaser, whichever is longer.

8. Special Packing, Marking, and/or Delivery Instruction - Goods shall be properly packed for the best and the most economical means of transportation from the manufacturer to the destination in Kyiv, Ukraine. Packaging shall protect the material from weather and damage due to ordinary means of handling. Marking and labeling of the material and its packaging shall be according to manufacturer's standards. 
Appendix E

Proposed Energy Efficiency Verification Process 


\section{Appendix E}

\section{Proposed Energy Efficiency Verification Process}

Verification of energy efficiency improvements can be a very difficult and complex task. The achieved reduction in energy consumption depends on many parameters: 1) the quality and accuracy of assumptions, calculations, and estimated efficiency improvements in the audit, 2) the quality of the installed technology, 3) the quality of the workmanship to install the measures, 4) the accuracy of the energy use evaluation/verification methodology used to quantify the achieved efficiency levels, and 5) the ability to account for any changes in energy consumption due to changes in occupancy, physical changes to the building, and climatic conditions of a given year.

Quantification of achieved efficiency improvement is an important part of the project. The borrower will want to know whether the investment is performing as expected and whether the planned efficiency improvements are achieved. The technical experts who calculated the performance of installed measures are interested in the project results, which will allow them to verify the reliability of calculation methods and assumptions, and to identify the benefits for the future project.

This discussion provides the basis for a verification plan for the retrofit of institutional sector buildings as identified in the Technical Assessment and the Lending and Implementation Assessment. It is expected that this plan will undergo further development by the PIO at the direction of the InterAgency Work Group as the definition of the project continues (note that the PIO and the Inter-Agency Work Group have not yet been established).

\section{E.1 The Verification Process}

Energy efficiency improvements are defined as the difference between the energy consumption prior to and after installation of the energy efficiency measure. Therefore, it is important to establish baseline energy consumption for each building under the existing conditions and to perform energy consumption measurement after the installation.

It is obvious that the energy consumption during each particular heating season is dependent on several factors, such as changes in building occupancy, schedule, and weather. These factors affect the total energy consumption together with energy consumption reduction by the efficiency measures. To evaluate the direct effect(s) of the efficiency measures, the effects of other factors must be eliminated, and all parties involved must have a full understanding of and agree with the evaluation methods. 
Evaluating performance of energy conservation measures may be very difficult and sometimes highly misleading if not completely understood. To establish a reliable means of evaluating energy efficiency investments, the DOE developed the North American Energy Measurement and Verification Protocol (NEMVP) (DOE 1996). It is recommended that the 'Whole-Facility Or Main Meter Measurement' option as described in the NEMVP (DOE 1996) be used.

Retrofit of each building involves several efficiency measures, such as the substation, installation of weatherization materials, etc. Many of the measures are interactive, and when installed together, it may not be possible to establish their individual impact on energy savings (in other words, it is not possible to assign precisely the percentage of energy efficiency improvement due to each particular measure). Therefore, it is recommended that verification of efficiency improvements be performed for the entire package of measures installed in the building.

\section{E.2 Data Collection}

Key components to verification are the installation of heat meters, providing for frequent collection and reporting of consumption data, and analysis of the data to verify performance of the installed measures. To the extent possible and practical, heat metering equipment will be installed in each building one heating season in advance to allow for a full heating season to collect baseline energy consumption measurements. Although available from other sources, it is recommended that ambient weather conditions also be collected during the heating season for proper data normalization. Major reasons for collecting ambient weather data are that this type of data may not be available from local sources, and there is a 6-month delay in obtaining the data from the National Climatic Data Center in Washington, D.C.

Table E.1 illustrates possible installation schedule by building type and heating season and also illustrates the staggered installation of heat meters and efficiency measures to enable the development of a baseline. This table separates the installations into heat meters and efficiency measures. Heat meters and control systems are most effective when installed at the same time. The actual installations would take this into account by completing the installation to accommodate the control systems, but not completing the installation of the control system or not enabling the control system, to permit the collection of baseline data to support the verification activity.

It is proposed that the heat meters be read by the onsite building manager/operator on a daily basis for the $98 / 99$ heating season and at least once a week during the subsequent heating seasons. When recording consumption data, the meters should be read on the same hour for the daily readings and on the same day and hour for the weekly readings. This data will then be transmitted to the PIO to estimate baselines for the building categories.

It is also proposed that ambient weather data be collected on a daily basis by the PIO for at least one location in the city. 
Table E.1. Illustrative Installation Schedule by Building Type and Heating Season

\begin{tabular}{|c|c|c|c|c|c|}
\hline \multirow[t]{2}{*}{ Installation of } & \multicolumn{5}{|c|}{ Heating Season } \\
\hline & 98/99 Phase I & $99 / 2000$ & $2000 / 2001$ & $2001 / 2002$ & Total \\
\hline \multicolumn{6}{|l|}{ Heat Meters } \\
\hline Healthcare & 100 & 120 & 119 & 0 & 339 \\
\hline Education & 100 & 598 & 598 & 0 & 1296 \\
\hline Cultural & 0 & 20 & 23 & 0 & 43 \\
\hline Total & 200 & 738 & 740 & 0 & 1678 \\
\hline \multicolumn{6}{|c|}{ Efficiency Measures } \\
\hline \multicolumn{6}{|l|}{ Healthcare } \\
\hline Education & $25^{(a)}$ & $105^{(\mathrm{b})}$ & $159^{(c)}$ & $50^{(d)}$ & 339 \\
\hline Cultural & $25^{(\mathrm{e})}$ & $430^{(f)}$ & $430^{(g)}$ & $411^{(\mathrm{h})}$ & 1296 \\
\hline \multirow[t]{2}{*}{ Total } & 0 & 0 & $20^{(i)}$ & $23^{(j)}$ & 43 \\
\hline & 50 & 535 & 609 & 484 & 1678 \\
\hline \multicolumn{6}{|c|}{$\begin{array}{l}\text { (b) } 75 \text { have had heat meters installed in the } 98 / 99 \text { heating season, and } 30 \text { have had heat meters installed } \\
\text { in the } 99 / 2000 \text { heating season. }\end{array}$} \\
\hline \multicolumn{6}{|c|}{$\begin{array}{l}\text { (c) } 90 \text { have had heat meters installed in the } 99 / 2000 \text { heating season, and } 69 \text { have had heat meters } \\
\text { installed in the } 2000 / 2001 \text { heating season. }\end{array}$} \\
\hline \multicolumn{6}{|c|}{ (d) The remaining 50 have had heat meters installed in the $2000 / 2001$ heating season. } \\
\hline \multicolumn{6}{|c|}{ (e) Included in the heat meter installations in the $98 / 99$ heating season. } \\
\hline \multicolumn{6}{|c|}{$\begin{array}{l}\text { (f) } 75 \text { have had heat meters installed in the } 98 / 99 \text { heating season, and } 355 \text { have had heat meters installed } \\
\text { in the } 99 / 2000 \text { heating season. }\end{array}$} \\
\hline \multicolumn{6}{|c|}{$\begin{array}{l}\text { (g) } 243 \text { have had heat meters installed in the } 99 / 2000 \text { heating season, and } 187 \text { have had heat meters } \\
\text { installed in the } 2000 / 2001 \text { heating season. }\end{array}$} \\
\hline \multicolumn{6}{|c|}{ (h) The remaining 411 have had heat meters installed in the 2000/2001 heating season. } \\
\hline \multicolumn{6}{|c|}{ (i) These 20 have had heat meters installed in the $99 / 2000$ heating season. } \\
\hline (j) These 23 hav & eeat meters insta & in the 200 & 01 heating s & & \\
\hline
\end{tabular}

Coupled with the collection of daily data, it is suggested that the 50 buildings with control systems installed in the $98 / 99$ heating season have the control systems enabled and disabled in alternating 2-week periods. This will provide for an increase in the sample size to estimate baseline consumption and, at the same time, permit an estimation of the postefficiency conditions to be estimated and evaluated.

\section{E.3 Calculating Efficiency Improvement}

A statistical estimation procedure is recommended where baseline consumption would be specified as a function of building size, operating hours, outdoor temperature, and perhaps other factors specific to the building type. The postinstallation (of the efficiency measures) consumption would be specified with 
the same equation plus a constant term (often referred to as a dummy variable) to provide for a decrease in consumption and/or an interaction term(s) to recognize a change in the behavior of consumption to the energy efficiency measures.

Significant deviations between actual and modeled baseline and postefficiency improvement consumption would be examined in detail by the cognizant PIO staff. Experience indicates that deviations are to be expected, but easily explained. The daily data collected in the first year will enable the development of a more robust set of equations to perform the subsequent verification.

Aggregate values of pre- and postefficiency improvement heat energy consumption will be used to support programmatic level verification by building category. Disaggregate values of pre- and postheat energy consumption, perhaps as disaggregate as the building level, will be used to identify, diagnose, and correct significant variances.

\section{E.4 Related Verification Data and Results Applications}

The heat meter data will also be used in the following activities to maximize energy efficiency improvements and ensure persistence:

- Audit: To support the calibration of computer models and improve the accuracy of the energy audits of the individual buildings.

- Incentives. To support the award of incentives (based on the verification) provided to organizations to foster participation.

- Training. To support the structure and content of training programs developed for and provided to building management staff.

- Operations and Maintenance. To support feedback provided to building management staff on the effects of day-to-day operations. 


\section{Distribution}

No. of

Copies

\section{OFFSITE}

2 DOE/Office of Scientific and Technical Information

3 The World Bank

Carolyn Gochenour

Senior Financial Analyst

Infrastructure Operations

Europe and Central Asia

The World Bank

1818 H Street, NW

Washington, DC 20433

Pentti Aro

District Heating Engineer

Infrastructure Operations

Europe and Central Asia

The World Bank

1818 H Street, NW

Washington, DC 20433

Konstantin Skorik

38/44 Pochainynska St.

$2^{\text {nd }}$ and $3^{\text {rd }}$ Floors

Kyiv, 252070

UKRAINE
No. of

Copies

3 U.S. Department of Energy

B. T. Castelli

Chief of Staff, Assistant Secretary for Energy Efficiency and Renewable Energy

U.S. Department of Energy

Forrestal Building, EE-1

1000 Independence Avenue, S.W.

Washington, DC 20585

G. H. Kats

Special Assistant, Assistant Secretary for Energy Efficiency and Renewable Energy

U.S. Department of Energy

Forrestal Building, EE-1

1000 Independence Avenue, S.W.

Washington, DC 20585

E. A. Arner

Staff Assistant, Office of Utility

Technologies, Assistant Secretary

for Energy Efficiency and Renewable Energy

U.S. Department of Energy

Forrestal Building, EE-10

1000 Independence Avenue, S.W.

Washington, DC 20585

Distr.1 
No. of

Copies

\section{FOREIGN}

2 Ukraine State Committee for Energy

Conservation

Sergey Bevz

Director of International Relations

State Committee for Energy Conservation

Gonty St.

Kyiv, 252112

UKRAINE

Georgy Panchenko

Deputy Director of International Relations

State Committee for Energy Conservation

Gonty St.

Kyiv, 252112

UKRAINE

4 Agency for Rational Energy Use and

Ecology

Sergey Surnin

ARENA-ECO

P.O. Box 48

1 Laboratorny St.

Kyiv, 252133

UKRAINE

Nikolai Raptsoun

ARENA-ECO

P.O. Box 48

1 Laboratorny St.

Kyiv, 252133

UKRAINE
No. of

Copies

Pavel Shestopal

ARENA-ECO

P.O. Box 48

1 Laboratorny St.

Kyiv, 252133

UKRAINE

Eugene Gagurin

ARENA-ECO

P.O. Box 48

1 Laboratorny St.

Kyiv, 252133

UKRAINE

16 Other

Tord Holmstrom

EnergiPlanerarna AB

Peter Myndes Backe 12, 5 Tr.

11846 Stockholm

SWEDEN

3 Peter Hobson, Principal Banker

Energy Efficiency

European Bank for Reconstruction and Development

One Exchange Square

London EC2A 2EH

UNITED KINGDOM

2 Lea Swanson, Director

Environmental Development

USAID Regional Mission

19 Nizhniy Val St.

Kyiv, 254071

UKRAINE 
No. of

Copies

10 Andrew Popelka

Tysak Engineering

29 Flint Road

Acton, MA 01720

\section{ONSITE}

226 Pacific Northwest National Laboratory

W. U. Chandler (10)

K4-06

M. Evans

BWO

S. L. Freeman (3)

K8-17

P. E. Killgo (175)

BWO

T. J. Secrest (32)

K5-16

Technical Report Files (5) 